\title{
Copyright and a Democratic Civil Society
}

\author{
Neil Weinstock Netanel ${ }^{\dagger}$
}

\section{CONTENTS}

I. THE EXPANSION of COPYRIGHT Holder RightS . . . . . . . . 292

A. Troublesome Areas of Copyright Expansion . . . . . . . . . . 297

1. Duration . . . . . . . . . . . . . . . . . . . . . 298

2. Personal Uses . . . . . . . . . . . . . . . . . . . 299

3. Transformative Uses . . . . . . . . . . . . . 301

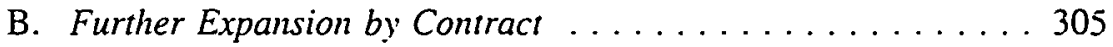

II. THE NeOClassicist APPROACH to Copyright . . . . . . . . . 306

A. Two Approaches to Copyright Economics . . . . . . . . . 308

B. The Neoclassicist Approach . . . . . . . . . . . . . 311

1. Neoclassicist Property Theory and Its Application to Copyright .................... . 314

a. Universality ................ 314

b. Concentrated Ownership ............ 317

c. Exclusivity ................... 319

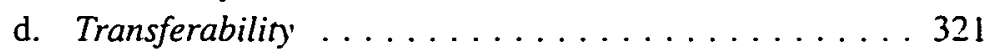

2. The Marginality of Law . . . . . . . . . . . . . 321

C. The Neoclassical Market Paradigm Versus Copyright's Democracy-Enhancing Goals . . . . . . . . . . . . . 324

III. The Minimalist Critics of Copyright Expansion . . . . . . 336

IV. THE Democratic Paradigm . . . . . . . . . . . 341

A. Democratic Govemance and Civil Socien. . . . . . . . . 341

B. Civil Society, the State, and the Market . . . . . . . . . . 344

C. Copyright and a Democratic Civil Society . . . . . . . . . . . 347

1. Copyright's Production Function ........... 347

i Assistant Professor, University of Texas School of LaH I would like to thanh the following persons for their helpful comments and suggestions regarding this Article Peler Broun. Willse Forbath. Mark Gergen, Wendy Gordon, Marci Hamilton. Doug Laycock. Bnan Lester. Mark Lemley. Jessica Litman. Ronald Mann, John Robertson, Charles Silver. Eric Talley, and the partucipants of the University of Texas School of Law Faculty Colloquium and Junior Faculty Roundiable at which I presented earlier drafts of this Article. My thanks also to Brett Swanson for his research assisiance 
2. Copyright's Structural Function . . . . . . . . . . 352

a. An Independent Expressive Sector . . . . . . . . 352

b. Imposition of Limits . . . . . . . . . . . 362

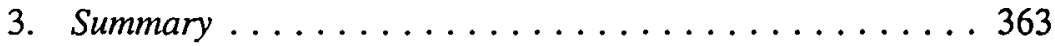

V. Doctrinal Outcomes in the Digital Public Square . . . . . 364

A. Copyright's Duration . . . . . . . . . . . . . 366

B. Personal Uses . . . . . . . . . . . . . . . . 371

C. Transformative Uses .................. . 376

D. Displacement of Copyright by Contract . . . . . . . . . 382

VI. CONCLUSION ..................... 386 
Copyright law strikes a precarious balance. To encourage authors to create and disseminate original expression, it accords them a bundle of proprietary rights in their works. But to promote public education and creative exchange, it invites audiences and subsequent authors to use existing works in every conceivable manner that falls outside the province of the copyright owner's exclusive rights. Copyright law's perennial dilemma is to determine where exclusive rights should end and unrestrained public access should begin. If copyright is cast too narrowly, authors may have inadequate incentives to produce and disseminate creative works or may be unduly dependent on the support of state or elite patrons. If copyright extends too broadly, copyright owners will be able to exert censorial control over critical uses of existing works or may extract monopoly rents for access, thereby chilling discourse and cultural development.

Digital technology threatens to upend copyright's already uneasy accommodation of public access with private ownership. Once a creative work is freely available online, anyone can, with a few clicks of a mouse, make perfect digital copies and limitless digital variations, and can electronically distribute them to the ends of the earth. If unauthorized and widespread, such user activity could radically undermine traditional copyright markets. At the same time, however, digital technology provides copyright owners with the technical means to restrict access to, and uses of, digitized works to a far greater extent than is possible in the analog and hard copy world. The systematic deployment of such technological fences would raise the specter of all-consuming copyright owner control.

Fueled by digital technology's destabilizing potential, an extraordinarily bitter battle is raging in Congress, ${ }^{1}$ the courts, ${ }^{2}$ law reviews, ${ }^{3}$ Internet

1. See NII Copyright Protection ACt of 1995: Hearings on H.R. 2441 Before the Subcomm. on Courts and Intellectual Property of the House Comm. on the Judician. 10sth Cong. (1996) (regarding proposed legislation to amend Copyright Act to make clear that nght of public distribution applies to computer network transmissions and to impose criminal penalties on circumvention of encrypted protection of copyrighted works).

2. See MAI Sys. v. Peak Computer, 991 F.2d 511.519 (9th Cir. 1993) (holding that copy is made when work is booted into RAM for longer than very bnef penod): Religious Tech. Cir $\vee$ Netcom On-Line Communications Servs., Inc., 907 F. Supp. 1361 (N.D. Cal. 1995) (holding that electronic bulletun board operator and Internet access provider are not direcily liable. but under certan circumstances may be contributorily liable, in connection with Usenet subscriber's postung of infninging messige to Usenet newsgroup); Sega Enters. v. Maphia, 857 F. Supp. 679 (N.D. Cal. 1994) (holding electronic bulletun board system operator directly liable for users' uploading and downloading of infnnging copies). Playboy Enters v. Frena, 839 F. Supp. 1552 (M.D. Fla. 1993) (same).

3. See, e.g., Niva Elkin-Koren, Copyright Law and Soctal Dialogue on the Information Supertughway The Case Against Copyright Liabiling of Bulletin Board Operators. 13 CARDOzo ARTS \& ENT L.J 346 (1995); Jane C. Ginsburg, Putting Cars on the "Information Superhighway" Authors. Explouters. and Copyright in Cyberspace, 95 ColUM. L. REV. 1466 (1995); 1. Trotter Hardy. Propern (and Copunghi) in Cyberspace, 1996 U. CHI. LEGAL F. (forthcoming Jan. 1997); Jessica Litman. The Exclustie Right ro Read. 13 CARDozo ARTS \& ENT. L.J. 29 (1994); Raymond T. Nimmer \& Patncia Ann Krauthaus. Copyright on the Information Superhighway: Requiem for a Middlewergh, 6 STAN. L. \& POL'Y REV 25 (1994). Pamela Samuelson, Digital Media and the Changing Face of Inielleciual Propert? Law. 16 RLTGers Cosuputer. 
discussion groups, ${ }^{4}$ and numerous international fora ${ }^{5}$ over the purpose and scope of copyright as we enter the digital age. On one side are U.S. business leaders, government officials, and others who have called for expanded copyright protection to support commercial development of the much-heralded National and Global Information Infrastructures. ${ }^{6}$ These proponents of an expansive copyright have drawn heavily upon emerging scholarship that applies an amalgam of neoclassical and new institutional economic property theory to copyright. This "neoclassicist" approach posits that, far from simply inducing the creation and dissemination of new expression, copyright serves as a vehicle for directing investment in existing works. ${ }^{7}$ Neoclassicists would accordingly treat literary and artistic works as "vendible commodities," best made subject to broad proprietary rights that extend to every conceivable valued use. ${ }^{8}$ In this manner, neoclassicists contend, market pricing can direct

\& TECH. L.J. 323 (1990); Diane Leenheer Zimmerman, Copyright in Cyberspace: Don't Throw Out the Public Interest with the Bath Water, 1994 ANN. SuRV. AM. L. 403.

4. See generally discussion on cni-copyright (visited Oct. 18, 1996) <gopher:/gopher.cni.org/11/ cniwg/forums/cni-copyright, and cyberia-1 (visited Oct. 18, 1996) <http://mailmunch.law.cornell. edu/listservs/cyberia>.

5. See, e.g., WORLD INTELLECTUAL PROPERTY ASS'N, WIPO WORLDWIDE SYMPOSIUM ON THE IMPACT of Digital. TEChNology on COPYRIGHT AND NeighboRing Rights (1993); European Comm'n, Green Paper on Copyright and Related Rights in the Information Society (last modifted Sept. 8, 1995) <hitp://www2.echo.lu/legal/en/ipr/ipr.html>.

6. See, e.g., INFORMATION INFRASTRUCTURE TASK FORCE, INTELLECTUAL PROPERTY AND THIE NATIONAL INFORMATION INFRASTRUCTURE; THE REPORT OF THE WORKING GROUP ON INTELLECTUAL PROPERTY RIGHTS 137-38 (last modified Sept. 1995) <http://www.uspto.gov/web/ipnii> [hereinafter NII WHITE PAPER]; see also Wendy J. Gordon, On Owning Information: Intellecfual Property and the Restitutionary Impulse, 78 VA. L. REV. 149, 156-57 (1992) (citing perception that greater intellectual property protection will enhance national prosperity as central factor in fueling dramatic expansion in scope of intellectual property over last two decades); Robert W. Kastenmeier \& David Beier, International Trade and Intellectual Property: Promise, Risks, and Reality, 22 VAND. J. TRANSNAT'L L. 285 (1989) (detailing growing importance of intellectual property to U.S. balance of trade and ultimately successful efforts by U.S. business leaders to include enforceable requirements for intellectual property protection within General Agreement on Tariffs and Trade).

7. I will refer broadly to this selective combination of neoclassical and new institutional economic property theory as "neoclassicism," even though self-proclaimed "new institutional" theorists generally distinguish themselves from, and, indeed, are critical of, what they define as neoclassical economic theory. See infra text accompanying notes 118-21. Similarly, I will refer broadly to copyright scholars who have expounded the neoclassicist approach as "neoclassicists," even though many have taken other approaches as well. See infra note 22.

8. The phrase is from Wendy J. Gordon, Assertive Modesty: An Economics of Intangibles, 94 ColUM. L. REv. 2579, 2579 n.I (1994) (stating that intellectual property law is fundamentally "a mode of converting mental labor into a "vendible commodity"' (citation omitted)). See also Frank H. Easterbrook. Intellectual Property is Still Property, 13 HARV. J.L. \& PUB. POL'Y 108, 118 (1990) (maintaining that "[e]xcept in the rarest case, we should treat intellectual property and physical property identically in the law").

Professor Gordon presented the neociassicist approach in an early article on copyright's fair use defense. See Wendy J. Gordon, Fair Use as Market Failure: A Structural and Economic Analysis of the Betamax Case and its Predecessors, 82 CoLUM. L. REv. 1600, 1605 (1982) [hereinafter Gordon, Fair Use]. To a limited extent in that article, and to a far greater extent in her subsequent work, she has argued that creative expression may serve important nonmonetizable interests and that copyright owners should not bc entitled to capture all social value derived from such expression. See Wendy J. Gordon, A Property Right in Self-Expression: Equality and Individualism in the Natural Law of Intellectual Property, 102 YALE L.J. 1533 (1993) [hereinafter Gordon, Self-Expression] (setting forth critique of copyright expansion based on Lockean natural rights theory); infra text accompanying notes 228-33 (questioning efficacy of Professor 
resource allocation for the marketing and development of existing creative expression in an optimally efficient manner.

On the other side, numerous critics have expressed serious misgivings over the political, cultural, and economic ramifications of expanded protection." In so doing, many such critics have espoused, in one form or another, what might be termed a minimalist position. In resisting further copyright expansion, they have proffered various approaches that would severely reduce existing levels of copyright protection. Some minimalist critics follow the same criterion of allocative efficiency as the neoclassicists, but reach diametrically opposed conclusions. They insist that the production of original expression is not inherently more valuable than any other potential use of society's resources, and thus that copyright protection must be set at a level that accounts not just for public access to expression, but also for the social cost of drawing resources away from other potential uses. ${ }^{10}$ Other critics phrase copyright's incentive rationale in minimalist terms. They recognize that authors' expression may have unique social value, but question whether the copyright incentive is truly necessary to induce its production and dissemination at an optimum amount and cost." Some minimalists tout the notion that copyright is an outdated impediment to "truth and exploration" in the digital universe." They argue that whatever copyright's value in the hard copy world, it simply has no place on the Internet. ${ }^{13}$ Others eschew such utopianism, but insist nevertheless that longstanding, predigital limitations to copyright owner prerogatives must be maintained even as digital network technologies radically alter traditional

Gordon's attempt, in her article on fatr use, to limi expanstonist tendeney of her early neculassictst position).

9. See Litman, supra note 3: Zimmerman, supra note 3: Pamela Sumuetson. The Copirtiht Grab. WIRED, Jan. 1996, at 134; see also NII Copyright Prolection Act of 1995: Hearngys on $H R$ 2\$fl Befork the Subcomm. on Courts and Intellectual Property of the House Comm. on the Juducum. 10ith Cong (1996) (statement of Members of Digital Future Coalition) (Feb. 15. 1996) (opposing cnactment of NII White Paper recommendations into law). Indeed, many critucs have argued cogently that, even without further expansion, copyright has already become an instrument of pnvate censorship. of the clevation of property rights over public access to the expressive foundations for challenging established sousal and cultural norms. See, e.g., James Boyle, A Theory of Law and Infornanon: Copirngh. Splecns. Blackmal. and Insider Trading, 80 CAL. L. REv. 1413, 1467-69 (1992); Gondon. Self-Expression. supra nole 8, Peler Jaszi, On the Author Effect: Contemporan Copyright and Collecure Creatwm. 10 CARDOzo ARTS \& EVT L.J. 293, 295 (1992); David Lange. At Play in the Fields of the Word: Copiright and the Consiructuon of Authorship in the Post-Literate Millennium, Law \& CONTEMP PROBS., Spnng 1992. at 139. Jesstca Litman, The Public Domain, 39 EMORY L.J. 965 (1990): Diane Leenheer Zummennan. Infornation As Speech. Information As Goods: Some Thoughts on Marketplaces and the Bill of Rights. 33 WW \& MARY L. REV 665 (1992); Brief of Amici Curiae Concemed Law Professons in Supporn of Petulioners al 18. Campbell v. Acuff-Rose Music, Inc., 510 U.S. 569 (1994) (No. 92-1292) (uaming of copynght owners propensity to seek "private censorship through copyright" and urging Court to establısh First Amendment defense for parody).

10. See infra text accompanying notes $255-57$

11. See infra text accompanying notes $258-62$

12. See Marci A. Hamilton, The TRIPs Agreement: Imperialtsitc, Outduted. and Oi erproted 1 e. 29 VAND. J. TRANSNAT'L L. 613,625-27 (1996) (criticizing "hachers". vew that copynght is outdated impediment to "truth and exploration").

13. See infra text accompanying notes 263-68. 
copyright markets. Although these critics generally purport to seek the retention of existing levels of protection, their proposed adherence to predigital "free use zones" would significantly undermine copyright's support for the autonomous creation and dissemination of expression in the digital environment. ${ }^{14}$

This Article presents a conceptual framework for copyright that stands in opposition to both the expansionism of neoclassicist economics and the minimalism of many critics. That framework, which I will label the democratic paradigm, emphasizes that copyright is in essence a state measure that uses market institutions to enhance the democratic character of civil society. In supporting a market for authors' works, copyright serves two democracyenhancing functions. The first is a production function. Copyright provides an incentive for creative expression on a wide array of political, social, and aesthetic issues, thus bolstering the discursive foundations for democratic culture and civic association. The second function is structural. Copyright supports a sector of creative and communicative activity that is relatively free from reliance on state subsidy, elite patronage, and cultural hierarchy. The democratic paradigm requires that copyright protection be sufficiently strong to ensure support for copyright's production and structural functions. But at the same time, it would accord authors a limited proprietary entitlement, designed to make room for-and, indeed, to encourage-many transformative and educative uses of existing works.

In contrast to the neoclassicist approach, the democratic paradigm emphasizes that copyright, like many institutions of civil society, is in, but not entirely of, the market. As I will argue, neoclassicism cannot serve as the basis for copyright doctrine because copyright's primary goal is not allocative efficiency, but the support of a democratic culture. Moreover, despite the Sisyphean efforts of some copyright scholars to confine neoclassicism within a democracy-enhancing framework, a copyright law driven by neoclassical economic property theory would give copyright owners such far-reaching control over productive uses of existing creative works that it would unduly constrain the robust debate upon which democratic self-rule depends.

At the same time, I will argue that much of the counteroffensive against copyright's precipitous expansion is misconceived. By adhering to a minimalist position, many critics have failed to account for the need to maintain autonomous, self-reliant authorship, especially in the face of rapidly changing markets. I will emphasize in contrast that "sustained works of authorship"15 — books, articles, films, songs, and paintings-form a central part of democratic discourse, and that a robust copyright is a necessary (though

14. See infra text accompanying notes 269-70, 399-401.

15. See Ginsburg, supra note 3, at 1499 (coining term "sustained works of authorship"). 
not necessarily sufficient) condition both for the creation and dissemination of that expression and for its independent and pluralist character.

The idea that copyright is in some way bound up with democratic governance is not new. In adopting the Constitution's Copyright Clause ${ }^{16}$ and enacting the first federal copyright statute, the Framers were animated by the belief that copyright's support for the diffusion of knowledge is "essential to the preservation of a free Constitution."17 Modern copyright jurisprudence contains a similar theme. It posits that the public education and discourse that undergird a democratic polity require a robust market for original works of authorship. ${ }^{18}$ As the Supreme Court affirmed a decade ago: "[T]he Framers intended copyright itself to be the engine of free expression."19

But the absence of a more rigorous, systematic understanding of how copyright supports democratic institutions has left this democratic theme vulnerable to both sides of the current debate over copyright's future. It has enabled neoclassicists to recast copyright as a mechanism for allocative efficiency, importing a theory of property that fails adequately to account for our fundamental, nonmonetizable interests in expressive diversity and informed citizenship. ${ }^{20}$ And it has left the critics without a coherent and convincing conceptual framework for countering copyright expansion while still providing for the robust public subsidy needed to underwrite authors' central role in our system of free expression.

The democratic paradigm that I will develop responds to copyright's continuing distention, but does so more selectively than have many of the critics. Reasserting copyright's fundamental principles requires a copyright that is sufficiently robust to support both copyright's production and structural functions. To that end, it requires that copyright be adapted to new technological means for disseminating authors' works and to the coming upheavals in the markets for many such works that will accompany the large-

16. U.S. CONST. art. I, $\S 8, \mathrm{cl} .8$.

17. In calling for the enactment of the first federal copynght statute in 1790. a Senate committee underscored the central imporance for the fledgling democracy of authors contributions to the store of knowledge, resolving that ..'[1]iterature and [s]eience are essentual to the presenalion of a free Constitution." BRUCE W. BUGBEE, GENESIS OF AMERICAN PATENT AND COPYRIGIT LAW 137 (1967) (quoting U.S. Senate Joumal, Ist Cong. 8-10: U.S. Annals of Congress, 1st Cong 935-36 1972 in some copies)). President Washington used similar language in his address to Congress in suppon of the statute See infra text accompanying note 339.

18. See PAUL GOLDSTEIN, 1 COPYRIGHT $\$ 2.2 .1$ at 2.10 (2d ed 1996): see also Barbara Runger. Two Hundred Years of American Copyrigh Law, in AMERICAN BAR ASS' $N$. TWO HUNDRED YEARS OF EVGLISH AND AMERICAN PATENT, TRADEMARK AND COPYRIGHT LAW 117. 118 (1977) ("We know, empincally, that strong copyright systems are charactenstuc of relatuvely free socielies ")

19. Harper \& Row, Publishers. Inc. v. Nation Enters. 471 US 539.558 (1985) tholding that unauthorized publishing of copyright protected memoirs was violation of copynghi), see ulso Pierre. $\mathbb{V}$ Leval, Toward a Fair Use Standard, I03 HARV. L. REV. 1105.1135 (1990) (“Although copynght often results in suppression of speech, its underlying objectuves parallel those of the tirst amendment ")

20. See Kathleen M. Sullivan, Free Speech and Unfree Markets. 42 UCLA L ReV 949. 963 (1995) (rejecting market metaphor in freedom of speech jurisprudence and noung that "(s)peech is an interaction arguably akin not to sales but to government"). 
scale electronic distribution of pictures, sound, and text in digital form. ${ }^{21}$ To extend copyright's limited monopoly blithely over all new uses may unduly burden the public domain, but unless changing markets are accounted for in redefining authors' exclusive rights, copyright's engine for free expression will be inadequately fueled.

Before addressing the best means to respond to copyright's expansion, it will be necessary to set forth more precisely the manner in which copyright has expanded. Part I briefly describes the three most controversial areas of copyright expansion, with an emphasis on their ramifications for the digital network environment: (1) the lengthening of the copyright term; (2) the extension of copyright to personal uses, including online "browsing" of protected expression; and (3) the constriction of authors' liberty to borrow from existing works in creating their own. Part I also examines the possibility of systematic contractual displacement of traditional limitations to copyright protection, an area of particular relevance to electronic distribution and online access.

Part II focuses on the principal theoretical support for copyright's continuing expansion, a combination of neoclassical and new institutional economic property theory. As I will discuss in Part II, such neoclassicist economics posits that social resources are best divided among private property owners who enjoy the absolute right to exclude nonowners and to exploit or dispose of their property as they wish. Neoclassicism applies to authors' expressive creations the same rarified market model that it applies to staples of commerce. It insists, accordingly, that copyright owners be given broad, exclusive rights over all valued uses of literary and artistic works and that prospective users must pay the owner's price except in anomalous cases of insurmountable market failure.

To be certain, the most thoughtful proponents of the neoclassicist approach among intellectual property scholars make a careful attempt to cabin their analysis within a framework that recognizes copyright's democracy-enhancing goals. ${ }^{22}$ But as I will discuss in Part II, this attempt is ultimately

21. For a discussion of anticipated upheavals in traditional copyright markets as a result of digital network distribution, see PAUL GOLDSTEIN, COPYRIGHT'S HIGHWAY: FrOM GUTENBERG TO THE CELESTIAL, JUKEBOX 197-236 (1994); Eugene Volokh, Cheap Speech and What It Will Do, 104 YALE L.J. 1805 (1995); John Perry Barlow, The Framework for Economy of Ideas: Rethinking Patents and Copyrights in the Digital Age, WIRED, Mar. 1994, at 83; Esther Dyson, Intellectual Value, WIRED, July 1995, at 136. See also Doreen Carvajal, Book Publishers Worry About Threat of Internet, N.Y. TIMES, Mar. 18, 1996, at Al. For a more conservative view of the inroads that digitization will make in markets for hard copy texts, sec

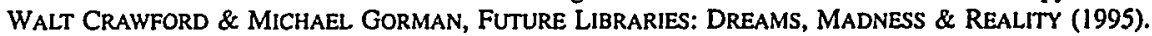

22. See infra text accompanying notes 188-91. In addition, these scholars have sometimes presented views of copyright that, at least in part, fall outside of the neoclassicist approach. See, e.g., Paul Goldstein, Copyright, LAW \& CONTEMP. PROBS., Spring 1992, at 79, 80, 86 (emphasizing copyright's support for author's creative autonomy); Gordon, Self-Expression, supra note 8 (presenting natural rights approach to copyright that emphasizes need to limit copyright owner rights to far greater extent than neoclassical economic analysis); Robert P. Merges, Intellectual Property and the Costs of Commercial Exchange: $A$ 
unsuccessful. To the extent that they employ a neoclassical market model as their analytic baseline, even these scholars are pushed in the direction of a broad, absolutist copyright. They are inclined to treat limitations on copyright owner prerogatives as isolated deviations from a marketplace norm, rather than as a fundamental component of copyright's democracy-enhancing equation. Ultimately, given the universalist thrust of economic property theory and the seeming value-neutral simplicity of the neoclassical market model, neoclassicist analysis tends to relegate to the margins the less monetizable public interest in expressive diversity and political competency. ${ }^{23}$

Part III summarizes and critiques the minimalist positions of many critics of expansion. It concludes that those critics, in one form or another, give an impoverished account of copyright's production function and overlook copyright's important structural function. As such, the minimalist position would lead to a truncated scope of protection that would lend inadequate support for copyright's constitutive goals.

Part IV sets forth my proposed conceptual framework for redirecting copyright toward its core understanding of public benefit, that of fortifying our democratic institutions by promoting public education, self-reliant authorship, and robust debate. More precisely, this democratic paradigm views copyright law as a state measure designed to enhance the independent and pluralist character of civil society. Part IV begins by examining the importance of civil society for democratic governance. It emphasizes the need for state support for democratic association, including the selective use of market institutions to support citizens' political competency, political autonomy, and associational diversity. Part IV then sets forth the role of copyright, as one such measure, in supporting a democratic civil society. It asserts that copyright-supported public discourse constitutes a vital component of civil society and that copyright promotes the democratic character of that discourse by underwriting an independent expressive sector and setting limits on private control of creative expression.

Part V revisits the troublesome areas of expansion discussed in Part I, describing in each instance how the democratic paradigm suggests different solutions than the neoclassicist and minimalist approaches. Like any jurisprudential framework, the democratic paradigm raises certain issues and

\footnotetext{
Review Essay, 93 MiCH. L. REV. 1570. 1613 (1995) (favonng premption of industr -uide standard contracts that effect "wholesale subversion of an important federal policy")

23. For a powerful argument that the thetoric of law and oconomics tends to marginalize the values required for human flourishing generally, see MARGARET JANE RADIN. CONTESTED CONMODITES 79-94 (1996). See also SUSAN ROSE-ACKERMAN, RETHINKING THE PROGRESSIVE AGEVDA. THE REForM OF THE AMERICAN REGULATORY STATE 22-23 (1992) (noting neoclassica! iendency to focus on individual transactions and neglect broader social policy); Rober W. Gordon. Unfreesing Legal Reulin Cruical Approaches to Law, 15 FLA. ST. U. L. REV. 195 (1987) (pounung out that free market chotce model of contract law fails to account for true nature of individual relationships and autonomous chorces)
} 
points in certain directions; it does not lead mechanically to particular doctrinal results. My focus in Part V, therefore, will be to highlight a few possible, logically consistent applications of the paradigm, not to insist that a democratic copyright must necessarily resemble my description in every detail.

\section{THE EXPANSION OF COPYRIGHT HOLDER RIGHTS}

Absent massive government or private subsidy, some measure of copyright protection is necessary to support a viable sector of authors and publishers engaged in the creation and dissemination of original expression. Unlike most goods and services, creative and informational works can be enjoyed by unlimited numbers of persons without being consumed. ${ }^{24}$ This means that, as a general rule, once a work is produced, the marginal cost of disseminating it to the public, whether in hard copy or electronically, approaches zero. ${ }^{25}$ Copyright protection is necessary because, in its absence, unbridled competition from free riders who are able to copy and distribute the work without paying copyright royalties would drive the price for user access to its near-zero marginal cost. ${ }^{26}$ This free rider problem, in turn, would greatly impair author and publisher ability to recover their fixed production costs. ${ }^{27}$ In a world without copyright, only authors unconcerned with monetary remuneration would produce creative expression and only publishers with no need for financial return would invest in selecting, packaging, marketing, and

24. For example, many persons may read a book, listen to a radio program, or view a painting without preventing others from doing the same or in any way diminishing the value of the work. In some instances, in fact, given network effects, the more people that enjoy a work, the greater may be its value for each user. See Michael L. Katz \& Carl Shapiro, Systems Competition and Network Effects, J. ECON. PERSP., Spring 1994, at 93. However, this might not always be the case with every type of creative work. For example, in determining basic prices for various uses of their photographs, stock photo agencies typically give considerable weight to the idea that much of a photograph's value lies in its "freshness"; the more people that view a photograph, the more its "freshness" is believed to have been consumed. See Timestream, Inc., Licensing Still Images: Some Basic Information for Multimedia Producers, at app. C (last modified Sept. 1994) <http://www.timestream.com/web/info/license.html>.

25. See Harold Demsetz, The Private Production of Public Goods, 13 J.L. \& ECON. 293, 295 (1970).

26. Such copying competitors are "free riders" in the sense that they do not share in the copyright owner's costs of creation, initial production, and marketing. Since competitors generally would copy only those works that have proven to be a success, they also "free ride" on the copyright owner's efforts to select which works to produce.

27. See William W. Fisher III, Reconstructing the Fair Use Doctrine, 101 HARV. L. REv. 1661, 1700 (1988). In markets in which copyright owners enjoy lead time advantages or are able to distribute qualitatively superior copies, they might be able to obtain some financial retum despite unhindered copying. But digital technology has the potential to erase these advantages. It enables copiers, quickly and inexpensively, to make and disseminate perfect quality reproductions. In addition, as consumer copying becomes easier, cheaper, and of higher quality, as is the case with digital technology, the authors' ability to recover fixed costs may be threatened by nonpurchasing consumers no less than by free riding competitors. As a resuit, copyright protection is all the more important in the digital environment, except to the extent that copyright owners can (and, as a matter of public policy, should) rely on technical means to prevent unauthorized copying or are able to recover their investment from the provision of peripheral services rather than the sale of expressive content. See infra text accompanying notes 353-56. 
making such expression available to the public. ${ }^{28}$ Without copyright, creative expression would likely be both underproduced and, no less importantly, underdisseminated.

But copyright is an imperfect remedy for the free rider problem that would otherwise plague the market in creative expression. While copyright may provide a necessary incentive, it does so at the cost of burdening whatever uses of copyrighted expression fall within the scope of the owner's copyright. Copyright operates by creating an artificial scarcity in copies or other means of gaining access to an expressive work and by giving the copyright owner a monopoly in the market for such access. ${ }^{29}$ As a result, copyright owners are able to charge substantially more than the marginal cost for access to expressive works. ${ }^{30}$ Consequently, some people who would have been willing to purchase access at somewhat more than its marginal cost, but at less than the supracompetitive price, now will not purchase it at all. "The result is a deadweight loss to society. ${ }^{32}$

28. My reference here and elsewhere to "publishers" is meant to connote any person or entuty that engages in selecting creative expression and making it avalable to the public Publishers would thus include, in addition to print and music publishers: sound recording. mulumedia, film, and television producers; digital content providers; an gallery owners; and others.

29. Access might be in the form of the purchase or rental of a hard copy (book or CD). electronic access (TV, radio, or electronic database), or onsite public performance or display (move or museum)

30. The size of this potential monopoly surcharge will be a function of the extent to which olher works might substitute for the work in question and the extent to which the copynght owner can engage in pnce discrimination. See Glynn S. Lunney. Jr., Reexamining Copyright's Incentures-Access Paradigm. 49 VA\D L. REV. 483, 520-21 (1996); Stewart E. Sterk, Rhetoric and Realing in Copynght Law, 99 Micit L REV 1197, 1205 (1996). Digital technology significantly enhances copynght owner ability to engage in pnce discrimination. First, it enables users to be charged for each discrete use when the use takes place As a result, the copyright owner may determine a differential use fee on a daly or hourly basis for each type of use. Second, digital technology accords content providers with an unprecedented ability to build. sell. and use individual consumer profiles. Once consumer preferences are identitied. users could be charged a greater amount for those uses and types of works that they most value. See GolDsten, supra note 21. at 8, 178-79, 202; see also A. Michael Froomkin. Flood Control on the Informuthon Ocean Lving With Anonymity, Digital Cash, and Distributed Databases, 15 J.L. \& CoM. 395. 450-88 (1996) (discussing digital payment systems and consumer profiles).

31. In theory, perfect price discrimination would make it posssble for the creator to produce both the work and the optimal number of copies. Of course, this would also enable the producer to capture all of the consumer surplus. See Demsetz, supra note 25. at 301-04 (discussing possibulaties for price discrimination in sale of public goods). Of course, perfect price discrimination would also bning copynght owners a maximum share of consumer surplus since they could charge each consumer the full amount she would be willing to pay for access to the work.

32. Defined in terms of traditional welfare economies, deadueight loss consists of in o components (1) the extent of the lost satisfaction experienced by each consumer who is unable to purehase the product because of its monopolistic price; and (2) the number of consumers who expenence such loss See Lunney. supra note 30 , at 564 . The copyright monopoly also enables the copynght ou net to capture a large share of the consumer surplus with respect to a work. especially when the owner can engage in discrnminatory pricing. However, economists generally see this as solely a matter of disinbution. without any appreciable effect on allocative inefficiency. See Fisher. supro note 27. at 1702 Richard Posner has noted that the social costs of monopoly pricing for intellectual property are essentually no different than the indispensable demarcation and enforcement costs of using a property nghts system to allocate any resource. and has maintained that so long as the benefits of establishing the property system exceed its cost. 11 will be and should be established. See RICHARD A. POSNER, ECONONIC ANALYSIS OF LAw 35, 39-40 (4th ed 1992) 
Given this tension between copyright benefits and costs, the question of how much incentive is appropriate is central to copyright policy and jurisprudence. It is against the background of this policy dilemma that copyright's continuing expansion must be evaluated.

Today's copyright owners enjoy an unprecedented ability to restrict personal uses of copyrighted expression and to constrain subsequent author borrowing from existing works in the creation of new ones. While such expansion may, at least to some degree, serve as a beneficial incentive for the dissemination of creative expression, ${ }^{33}$ it also poses the danger of chilling discourse and cultural advancement, thus defeating copyright's essential democratic purpose. A bloated copyright frustrates copyright's democracyenhancing goals in two basic ways. First, on too many occasions, copyright owners have sought to use their proprietary entitlements blatantly to suppress political, social, or personal criticism. A number of published cases, which one may assume are only the tip of the iceberg, are especially disturbing. The Church of Scientology has recently invoked copyright to prevent critics from bringing allegedly corrupt Church practices to public scrutiny. ${ }^{34}$ J.D. Salinger and Howard Hughes each brought a copyright infringement action to suppress

33. Expansion that has, on the whole, been more beneficial than troublesome includes the extension of copyright protection to new forms of expression and new means of dissemination. The first federal copyright statute, the Copyright Act of 1790, extended protection only to books, maps, and charts. See Act of May 31,1790 , ch. 15, $\S 1,1$ Stat. 124, 124. However, copyright law now provides incentives for the creation and dissemination of a broad range of cultural expression, including works of visual art, music, architecture, choreography and others, like sound recordings, photographs, and film, that did not exist in 1790. An 1802 amendment to the copyright law added engravings and prints. See Act of Apr. 29, 1802, ch. 36, § 2, 2 Stat. 171. The 1831 copyright law revision added musical compositions. See Act of Feb. 3, 1831, ch. 16, § 1, 4 Stat. 436. An 1865 amendment added photographs. See Act of Mar. 3, 1865, ch. 126, $\S 1,13$ Stat. 540. The Copyright Act of 1870 added paintings, drawings and statues. See Act of July 8 , [870, ch. $230, \S 86,16$ Stat. 198, 212. The Copyright Act of 1976 broadly protects all "original works of authorship fixed in any tangible medium of expression, now known or later developed, from which they can be perceived, reproduced, or otherwise communicated, either directly or with the aid of a machine or device." 17 U.S.C. $\S 102$ (a) (1994). As originally enacted, the Act also enumerated seven categories of works of authorship, including (1) literary works, (2) musical works, (3) dramatic works, (4) pantomimes and choreographic works, (5) pictorial, graphic, and sculptural works, (6) motion pictures and other audiovisual works, and (7) sound recordings. In 1990, an eighth category, architectural works, was added, pursuant to the Architectural Works Copyright Protection Act, tit. 7, § 701, 104 Stat. 5133 (1990) (codified at 17 U.S.C. \$ 101 note). Today's copyright law also recognizes important means of disseminating expression other than simply printing and distributing copies. These include public performance and public display. See 17 U.S.C. $\S 106(4)-(5)$ (1994). They also encompass new technological means of dissemination, including cinema, phonorecords, broadcast, and electronic reprography. The showing of films at the cinema and the broadcast of fixed or simultaneously recorded works on television or radio constitute a public performance of such works within the meaning of 17 U.S.C. $\S 106(4)$. Under section 106(1) of the Copyright Act, the right to make copies includes the reproduction of works in phonorecords and technological means of reproduction such as electronic reprography. For an extensive discussion of the application of copyright to new technological uses of works of authorship, see NATIONAL COMM'N ON NEW TECHNOLOGICAL USES OF COPYRIGHTED WORKS, FINAL REPORT 82 (1979) [hereinafter CONTU). Copyright's extension into these areas underwrites a rich and varied system of culture and dialogue. In today's multifarious market, to limit copyright to its original parameters would be to consign it to oblivion.

34. See, e.g., Religious Tech. Ctr. v. Netcom On-Line Communication Servs., 907 F. Supp. 1361 (N.D. Cal. 1995). 
the publication of biographical material. ${ }^{35}$ Walt Disney Productions obtained an injunction against the publication of a counterculture comic book that sought to contest Disney's all-American "'world of scrubbed faces, bright smiles and happy endings"' by depicting Mickey Mouse engaged in various illicit activities. ${ }^{36}$ A Minneapolis police officer brought suit to prevent a newspaper from exposing his racist fable, which had appeared in a police department newsletter. ${ }^{37}$

Second, expanded copyright imposes an ever more burdensome "tax" on audiences and subsequent authors. ${ }^{38}$ Expanded control may increase the private cost of reading, viewing, and listening to authors' expression to such an extent that, in some cases and for some people, access becomes prohibitively expensive. ${ }^{39}$ Although digital technology may make possible highly refined price discrimination that could, in theory, alleviate this problem, the prospect of a regime in which consumers are charged for each and every digital use has raised serious concerns about its potential distributional impact. $^{40}$

An overly expanded copyright also constitutes a material disincentive to the production and dissemination of creative, transformative uses of preexisting expression. Indeed, a broad, expanded copyright may, in effect. stifle

35. Salinger was successful. See Salinger v. Random House. Inc., 811 F $2 \mathrm{~d} 90$ (2d Car 1987) iholding that biographer's quotations from Salinger's unpublished letters did not constitute faur use) Hughes was not. See Rosemont Enters. v. Random House, Inc.. 366 F.2d 303 (2d Cir. 1966) (1acatıng preluminan injunction restraining distribution of biography of Hughes that incorporated matenal from senes of magazine articles, copyright in which had been acquired by Hughes's holding company 1

36. See Walt Disney Prods. v. Air Pirates, 581 F.2d 751. 753 (9th Car 1978) (quoung Note, Purexh Copyrights and the First Amendment, 10 U.S.F. L. REV. 564. 571 (1976))

37. See Belmore v. City Pages Inc., 34 U.S.P.Q.2d (BNA) I295 (D Minn 1995,

38. The metaphor of copyright as a "tax" has a long and established pedigree. extending bach to Thomas Macaulay"s pronouncement. on the floor of Parliament in $18+1$ in opposition to a bill to lengthen the copyright term, that copyright imposes a "tax on readers for the bounly of wnter" ThowAs MACAULAY, SPEECHES ON POltTICS AND LITERATURE 177 (New Yorh. E.P Dutton \& Co 1924, 11841,

39. The extent to which copyright may pose significant bamers to reader. vewer, or listener steess will depend on a number of factors, including the degree of copynght owner market power for any given consumer use of a particular work (which is itself largely a factor of the substitutabilit) of alternative uses and works), copyright owner ability and willingness to engage in pnce discriminatıon based on consumer ability to pay, the percentage of total retail cost that is attributable to copynght, and the avalability of copyrighted material that is available without any direet consumer payment through deliertiser-supported broadcasting, public libraries, and other sources. Much theoretuc and empincal work needs to be done to determine more precisely how much of a "tax" copynght really imposes on consumers of vanous types of works and how much of a barrier to access such a "tax" represents.

40. See NII Copyright Protection ACt of 1995: Hearings on H.R 2\$4I Before the Subcamm on Courts and Intellectual Property of the House Comm. on the Judictan: 10:th Cong (1996) (statement of Amencan Association of Law Libraries, American Library Association. Assoctatıon of Research Libranes. Medical Library Association, Special Libraries Association) (expressing concem that copynght ouner ability to impose universal user charges "will take us a very long way lowards becoming a nation of information haves and information have-nots") (last modified Feb. 8. 1996) <hitp //uww an nevdfc/legislat librarie.htm"tala>; Niva Elkin-Koren, Cyberlaw and Soctal Change A Democranc Approuth so Copiright Law in Cyberspace, 14 CARDOZO ARTS \& ENT. L.J. 215, 26t-67 (1996) (maintanning that digital distribution and discontinuation of libraries" provision of free access to infomation may exaicrbate socioeconomic inequality); Zimmerman, supra note 3, at 410 (discussing posstble thilling effect on students, scholars, and library users of having to pay for each use) 
transformative uses in a way that parallels, but is far more systematic than the problem of private censorship. All creative expression involves borrowing from earlier works, to one degree or another, whether in the form of literal or nearliteral quotation (as in T.S. Eliot's pastiche of literary greats in The Waste Land), reformulation of basic plot (as in West Side Story's adaptation of Romeo and Juliet), or influence of style (as in the genre of Impressionist painting). ${ }^{41}$ To the extent that copyright in an author's potential source material requires payment for the quotation, reformulation, adaptation, or parody of that material, some such transformative uses will never transpire. ${ }^{42}$ In a very real sense, it does not matter whether a transformative use is silenced by deliberate copyright owner suppression or secondary author inability or unwillingness to pay the copyright owner's price. Regardless of the reason, the resulting harm to cultural development and expressive diversity is the same: transformative expression has been muted.

Significantly, the social harm resulting from this silencing of transformative expression goes far beyond the loss to consumers who would otherwise have paid to read, view, or listen to it. Robust public debate, the spread of knowledge, and the questioning of cultural hierarchy are of paramount importance to a democratic society. To the extent that these activities bolster democratic institutions, all citizens benefit from their occurrence.$^{43}$ Accordingly, as a citizen of a democratic society, I benefit from the ability of secondary authors to reformulate and challenge the social meaning of cultural icons, to expose corrupt or racist practices of powerful

41. For a comprehensive study of artistic influence, see GORAN HERMEREN, INFLUENCE IN ART AND LITERATURE (1975). For a more succinct, but highly useful discussion, see RICHARD A. POSNER, LAW AND LITERATURE: A MISUNDERSTOOD RELATION 343-51 (1988).

42. Especially given copyright owner ability to demand supracompetitive license fees, a market power enhanced by according owners broad exclusive rights, would-be transformative authors often will be unable or unwilling to pay the copyright owner's price. See Lunney, supra note 30, at 521-22 (discussing enhanced market power from broad copyright protection). In some cases, due in part to persistent market imperfections, secondary authors will be unable to recover their costs from consumers of their work. In others, they might possibly be able to recover their license fee, but they will be unable or unwilling to bear the substantial risk of failing to do so. In still others subsequent authors might, in theory, be willing to pay the copyright owner's price, but not the additional costs of negotiating and obtaining a license. For a further discussion of market impediments to transformative use licenses, see Mark A. Lemley, The Economics of Improvement in Intellectual Property Law, 75 TEX. L. REV. (forthcoming May 1997). Paul Goldstcin contends that "transaction costs will commonly hobble the making of nontransformative copies . . . to a far greater degree than they will transformative copies." GoLDSTEIN, supra note 18, $\$ 10.2 .2$, at 10:43. Even if once true, this is often no longer the case, and certainly will not be so in the digital network environment. With the emergence of collective photocopy licensing, digital tracking, and automatic electronic payment, transaction costs for simple, nontransformative copying will drop to next to nothing. But even in a digital environment, transformative uses will often require individual assessment and negotiation, since copyright owners will want to ensure that the particular transformative use that is proposed will not interfere with their development plans or run contrary to their views.

43. Even from a completely atomistic, self-interested point of view, individuals benefit from democracy, because democratic government is generally a better guarantee of individual autonomy and freedom from oppression than are other forms of government. See Stephen A. Gardbaum, Broadcasting, Democracy, and the Market, 82 GEO. L.J. 373, 387-88 (1993) (arguing that democratic government is necessary, although not sufficient, condition for individual autonomy). 
institutions, and to publish biographical material about public figures even if I never personally purchase or even see the transformative work. Given its significant role in democratic discourse, transformative expression-particularly transformative expression that is not controlled by the owner of the source material-carries a social value far in excess of the aggregate price that consumers would pay for personal access to transformative works. ${ }^{\text {th }}$ And an analogous claim can be made with regard to copyright's tax on readers, viewers, and listeners. Given the interest of a democratic society in an educated citizenry and an inclusive, national culture, when some persons are unable to acquire access to expressive works, the harm is arguably not just to them as individuals, but to society as a whole.

This is not to say that copyright expansion need necessarily be curtailed in each instance. Expansion's detrimental effects on users might in many cases be offset by increased encouragement of the creation and dissemination of original expression. Each area of copyright expansion must therefore be critically examined in light of copyright's essential democratic purposes.

\section{A. Troublesome Areas of Copyright Expansion}

The most troublesome areas of expanded copyright protection for cultural expression may be divided into three basic sorts: duration, personal uses, and transformative uses. ${ }^{45}$

44. In economic terms, transformative expression can be sand to yicld soctal benefits that remain external to the decisions of market actors. More strongly. one could argue that transformative expresstion is what Charles Taylor has called an "irreducibly social good." a good whose value cannot be measured or described in terms of the metric of individual preferences. but rather denves from shared meanings and collective decisionmaking. See Charles Taylor, Irreductbly Social Goods. in RAnoNALITY. INDividi Alisu AND PUBLIC POLICY 45 (Geoffrey Brennan \& Cliff Walsh eds., 1990). For the purposes of my argument. it makes no difference whether the benefits of transformatuve expression (or, for that matter, of copynght as a whole) are seen as irreducibly social goods or intractable exiernalities. The point in either case is that market transactions in a broad, proprietary copyright cannot be relied upon to funther or reflect the public interest in expressive diversity, whether that public interest is seen as an organic whole or as an aggregation of individual preferences.

45. A fourth troublesome area of copyright expansion, but one that does not directly involve cultural expression, is the extension of copyright protection to computer programs. Which pnmanly serves a utilitarian function rather than directly communicatung an idea to a reader. listenes, or observer lOf course. computer programs may be used as tools for communication, much like pens, paint brushes, or motion picture projectors. Their immediate purpose, however, is to direet the functions of a computer, not to communicate to humans.) Computer programs are ostensibly protected as literany works, but cours have effectively accorded them a quasi-sui generis protection that better comports with their functional nature See Pamela Samuelson et al., A Manifesto Concerming the Legal Protection of Computer Proyrams. 94 COLUM. L. REV. 2308, 2359-61 (1994). The extension of copynght protection to computer programs. tirst by Congress and then, at the insistence of the United States. in the Agreement on Trade Related Aspects of Intellectual Property, is an anomalous case, arising from the strong perceived need for protection and the ready availability of copyright in domestic and intemational arenas. See id. at $2348 \mathrm{n} 1.46$ th thas been sharply and extensively criticized by courts and commentators. See. e.g., Computer Assoes Ini'l. Inc $v$ Altai, Inc., 982 F.2d 693, 704 (2d Cir. 1992) (stating that "the essentially uthltanan nature of a computer program . . . complicates the task of distilling its idea from its expression"): $u$. at 712 (regarding much software copyright case law as "the courts" attempt to fit proverbial square peg in a round hole"). 


\section{Duration}

The first, and most straightforward, area concerns the duration of copyright protection. The Constitution's Copyright Clause and the public benefit rationale for copyright that it embodies dictate that the copyright owner's exclusive rights be limited in time. ${ }^{46}$ If copyright's purpose is to promote learning and discourse, then at some point the public must be able freely to copy, modify, and reformulate the works that have become a part of its cultural matrix. ${ }^{47}$ Mindful of this need, Congress limited copyright to a once renewable 14-year term in the first federal copyright statute, the Act of May $31,1790 .{ }^{48}$ Since then, however, the copyright term has increased slowly, but markedly. In 1831, Congress doubled the original term ${ }^{49}$ and, as part of the general copyright revision of 1909, it doubled the renewal term. ${ }^{50}$ That maximum 56-year term remained in force until the enactment of the Copyright Act of 1976, which extended the duration of the copyright owner's exclusive rights to the life of the author plus 50 years. ${ }^{51}$

There is now legislation pending before Congress that would further lengthen the copyright term to the author's life plus 70 years. ${ }^{52}$ Proponents of the legislation argue that term extensions reflect the increasing economic value of copyrighted works and that without exclusive rights in the marketplace, publishers will not invest in the restoration and dissemination of old works in either digital or hard copy format. ${ }^{53}$ Critics maintain that a

Samuelson, supra, at 2310 . This Article will focus solely on the issue of copyright expansion in the arca of cultural expression.

46. The Copyright Clause empowers Congress to secure authors' exclusive rights for "limited times." See U.S. CONST. art. I, $\$ 8$, cl. 8.

47. As David Nimmer has cogently stated, under copyright's traditional public good rationale, "works are relegated to the public domain to become the heritage of all humanity and copyright is simply a temporary way station to reward authors on the road to that greater good." David Nimmer, The End of Copyright, 48 VAND. L. REV. 1385, 1416 (1995).

48. Under the 1790 Act a copyright could be renewed for a second fourteen-year term if the author was still living at the expiration of the first term. See Act of May 31, 1790, ch. 15. § 1, 1 Stat. 124, 124.

49. See Act of Feb. 3, 1831, ch. 16, 4 Stat. 436.

50. See Act of Mar. 4, 1909, ch. 320, $\$ 23,35$ Stat. 1075, 1080.

51. See 17 U.S.C. $\$ 302$ (a) (1994). In the case of works made for hire or works where the author is not identified at all or by his real name, the copyright endures for a term of 75 years from the work's first publication or 100 years from its creation, whichever is shorter. See id. $\$ 302$ (c). Works created, but not published or copyrighted prior to January 1, 1978, and works in which copyright already subsisted on January 1, 1978, are protected for different terms pursuant to sections 303 and 304, respectively. See id. § 303-04.

52. See H.R. 989, 104th Cong. (1995); S. 483, 104th Cong. (1995).

53. See Copyright Term Extension Bill Gets Mixed Reaction in House Hearing, 50 Pat., Trademark \& Copyright J. (BNA) 282, 283 (1995) [hereinafter Mixed Reaction] (testimony of Commissioner of Patents and Trademarks Bruce Lehman); Copyright Term Extension Bill Is Praised at Committee Hearing, 50 Pat., Trademark \& Copyright J. (BNA) 589, 590 (1995) [hereinafter Bill is Praised] (testimony of Commissioner of Patents and Trademarks Bruce Lehman). Proponents also argue that the extension is desirable 10 harmonize U.S. law with a recently adopted European Union directive to its member countries to set their copyright terms at the life of the author plus 70 years so that U.S. copyright owners will not be deprived of additional European royalties. See Mixed Reaction, supra, at 282 (testimony of Deputy U.S. Trade 
further diminution of the public domain would seriously hinder the creation of new works and would impose costs on the public that are not warranted by the incentive rationale. $^{54}$

\section{Personal Uses}

The second controversial area of expansion is the extension of copyright to personal uses of cultural works. Until the advent of photocopiers, VCRs, cassette recorders, and other consumer copying equipment, copyright's principal concern was the infringing competitor who might invest the large sums required to print and sell unauthorized copies to the public. The rare individual who took the trouble to hand copy all or part of a book for her own use posed no real threat to the publisher's ability to market the author's work. The same was true of individuals (or even institutions like used book stores and libraries) who sold or lent used copies. The purchase or borrowing of a used copy, some time after the work came onto the market, was unlikely to substitute for the purchase of a new copy. ${ }^{55}$ Partly as a result of this de minimis market harm and partly out of a desire to avoid unwarranted intrusion on individuals' private affairs and property rights, handwritten home copying of published works and the disposition of lawfully acquired copies have not traditionally been deemed to constitute an infringement of copyright. ${ }^{\text {\$6 }}$

With readily available consumer electronics and digital technology, however, individual consumers are now able to make perfect copies of many cultural works at virtually no cost. If left unchecked, massive consumer copying could undermine publisher markets no less than could infringing

Representative Charlene Barshefsky); Bill is Praised, supra, at 590 (testumony of Register of Copynghts Marybeth Peters).

54. See Mixed Reaction, supra note 53, at 283 (iestimony of Prof. Dennis Kanala), Bull is Pratsed. supra note 53, at 591 (testimony of Prof. Peter Jaszi).

55. Indeed, in the early years of copyright relatively few individuals could afford to acquire books on a regular basis and, accondingly, sales to libraries made up a significant source of publisher revenue. See CATHY Davidson, ReVolution AND the WORD: THE RISE OF thie NOVEL IN AMerica 27-28 (1986)

56. Although there is no reported case that explicitly holds as such, authontues have generally concurred that, except perhaps in unusual circumstances, a single handwritien copy of a protected published work made for the copier's own privale use would be noninfnngernent under the farr use doctnne or de minimis infringement doctrine. See, e.g. American Geophysical Union v. Texaco Inc., 60 F.3d 913.916 (2d Cir. 1994) (distinguishing systematic copying by company sesentists from "copying by an individual. for personal use in research or otherwise (not for resale)," which. "under the faur use doctnne or the de minimis doctrine ... might well not constitute an infringement"): Williams \& Wilkuns Co v. United States. 487 F.2d 1345, 1350 (Ct. Cl. 1973) ("[I]t is almost unanimously accepted thal a scholar can make a handwritten copy of an eutire copyrighted article for his own use."); of. MIELVILE B. NIMMER \& DAviD NIMMER, 3 NIMMER ON COPYRIGHT § 13.0S[E]. at 13-253 (1995) (hereInafter NIMIMIER ON COPYRIGHT] (recognizing that court might be impelled by "force of custom" to find that personal, handwntten copy would constitute noninfringing fair use, but arguing that such result could "not be reconctled with the rationale for fair use"). Under the "first sale doctrine," codified in section 109 of the Copynght Act. the owner of a copy of a protected work is generally free to sell. lend. or otherwise dispose of that copy. without the authority of the copyright owner. See 17 U.S.C. $\$ 109$ (a) (199.4). 
competitors. ${ }^{57}$ Electronic borrowing can also substitute for the acquisition of copies in ways that borrowing a used hard copy could not. With current, rapidly developing technology, library patrons can view digitized and electronically stored works from the comfort of their homes whenever and as often as they wish, even at the same time that many other patrons are viewing the same works. ${ }^{58}$ With the spread of such technology, which bypasses the temporal and physical limitations of hard copy borrowing, many more people will be able to gain access to cultural works without purchasing them. In fact, given easy and inexpensive access to electronic libraries, there might be little reason for most people to have their own copy of many types of works. ${ }^{59}$

In light of these developments, copyright owners have pushed to extend the reach of their exclusive rights to incorporate personal copying, secondary dispositions of purchased copies, and electronic borrowing. Thus far their success has been sporadic. Although the matter is far from settled, courts have generally declined to find personal copying as infringing. ${ }^{60}$ Congress has established a royalty scheme for digital audio recording, under which copyright owners receive a fee from the sale of digital recording equipment and media. ${ }^{61}$ But in return, Congress prohibited copyright owners from bringing infringement actions for noncommercial consumer recordings of music. ${ }^{62}$ In addition, pursuant to the "first sale" doctrine, purchasers continue generally to enjoy the freedom to dispose of purchased copies as they wish. Congress has thus far given copyright owners control over secondary dispositions only in the areas of computer program and sound recording rentals, where the dangers of renter copying are particularly apparent. ${ }^{63}$

On the other hand, Congress has provided, under the Copyright Act of 1976 , that the copyright owner's exclusive right of public display would extend

57. See Ginsburg, supra note 3, at 1477-78.

58. See Jan Olsen, Cornell University's Albert R. Mann Library: A Prototype for Today's Electronic Library, LIBRARY HI TECH, Dec. 1994, at 31, 32-37.

59. Cf. Volokh, supra note 21 , at 1809-17 (predicting that hard copy distribution of record albums will be replaced by commercial digital delivery of consumer-selected songs, of which in some instances consumers will purchase copy of the delivered music and in others, including pay-per-play and custom-mix radio transmission, they will not).

60. In Sony Corp. of America y. Universal City Studios, Inc., 464 U.S. 417 (1984), the Supreme Court held that home videotaping of television programs for purposes of "time-shifting," or watching a program after it has been broadcast, was a noninfringing fair use. More recently, the Second Circuit amended its opinion in American Geophysical Union v. Texaco Inc., 60 F.3d 913 (2d Cir. 1994), to clarify that its holding that archival copying by Texaco research scientists was an infringement did not extend to individual copying "for personal use in research or otherwise," which, the court recognized, "might well" be noninfringing "under the fair use doctrine or de minimis doctrine." Id. at 916.

61. See 17 U.S.C. $\$ \S 1003-07$ (1994).

62. See id. \$ 1008 .

63. See id. $\$ 109$ (b); see also Agreement on Trade Related Aspects of Intellectual Property Rights, Including Trade in Counterfeit Goods of the General Agreement on Tariffs and Trade, Apr. 15, 1994, arts. 11, 14, reprinted in SELECTED STATUTES AND INTERNATIONAL AGREEMENTS ON UNFAIR COMPETITION, TRADEMARK, COPYRIGHT AND PATENT 410, 415-16 (Paul Goldstein et al. eds., 1995) [hereinafter TRIPs] (requiring member states to accord commercial rental rights in computer programs, cinematographic works. and sound recording in certain circumstances). 
to a library's provision of remote electronic access to digitized works. ${ }^{\text {ot }}$ Moreover, in what may well portend further copyright expansion, the Clinton Administration's White Paper on Intellectual Property and the National Informational Infrastructure maintains that the private copying of electronically stored works, and even the viewing of a work on a computer screen without downloading it, should not generally be permitted without the consent of the copyright owner. ${ }^{65}$ The NII White Paper also concludes, in contrast to the spirit if not the letter of the first sale doctrine, that the unlicensed electronic transmission of a work from one person to another does and should constitute an infringement, even if the transmitter has simultaneously deleted his copy from his computer. ${ }^{66}$ If the NII White Paper position is adopted by Congress or the courts, the electronic equivalents of browsing through a magazine at a newsstand, lending a book to a friend, or borrowing a book from a library would fall within the province of the copyright owner's exclusive rights. ${ }^{67}$

\section{Transformative Uses}

The third troublesome instance of copyright expansion sharply constricts the extent to which authors may borrow from existing works in creating their own. Throughout most of the nineteenth century, authors were free to borrow from existing works as long as they made their own substantial contribution

64. Under the Copyright Act, "[t]o 'display' a work means to show a copy of 11 , enther directly or by means of a film, slide, television image, or any other device or process." 17 U.S.C $\$ 101$ (1994) (emphasis added). The House Repor accompanying the Act makes clear that "display" would apply to remote electronic access. It states that the term includes "the transmission of an image by electronic or other means, and the showing of an image on a cathode ray tube, or similar viesing apparatus connected with any son of information storage and retrieval system." H.R. REP. No. 94-1476. at 6f (1976) The Repon further notes that "the display of a visual image of a copynghted work would be an infinngement if the image were transmitted by any method (by closed or open circust television. for example. or by a computer system) from one place to members of the public located elsewhere." $/ d$. at 80

65. According to the White Paper, given the current state of computer technology. steutng matenal on a computer sereen, even without downloading it, consutules copjing. See NII WIITE PaPER. supru note 6, at 66. The White Paper grants that personal copying may constutute a fair use under current law, but strongly suggests that technological means of tracking transactions and licensing should lead to reduced application and scope of the fair use doctnne. See id. at 82 (technological tracking and farr use). Id. at 84 (copyright owners should not be "taxed" to provide unversal access); td. at 88 (electronic ordenng and payment may become effective substitute for interlibrary loan). Taking the more resincuve approach on an issue which has yet to be definitively decided in the courts. the White Paper would also impose on the user the burden of persuasion and coming forward with evidence of fasr use See ad at 73 n 229 For a discussion of judicial treatment of this issue, see infra note 232.

66. The White Paper contends that such a transmission actually consututes the making of a new copy of the work, rather than the transfer of the transmitter's copy. and as such the first sale doctnne does not apply. See NII WHITE PAPER, supra note 6, at 92-94. Ostensibly, the White Paper recognizes that some such transfers may be a noninfringing fair use, see $1 d$. at 93 . but the White Paper would sharply restnet the availability of fair use; see supra note 65 .

67. According to the authors of the White Paper. its position has already been adopted by the courts in decisions holding that booting works into computer RAM constltutes the making of a copy. See NII WHITE PAPER, supra note 6, at 65 n.204 (citing MAI Systems Corp v. Peak Computer, Ine . 991 F 2d 511. 519 (9th Cir. 1993)). 
and did not displace demand for the original work in its original form. ${ }^{68}$ In one landmark case, for example, the German translator of Uncle Tom's Cabin defeated Harriet Beecher Stowe's copyright infringement action against him; the court held that the translation was a new work and not merely a reproduction of the original. ${ }^{69}$ The principle that copyright is delimited by what the defendant has contributed began to erode in the late nineteenth century, however, and has continued steadily to crumble through the twentieth century. ${ }^{70}$

The Copyright Act of 1976 now accords copyright owners a broad, exclusive right to prepare derivative works based on the original. ${ }^{71}$ These include translations, arrangements, versions in other media, and "any other form in which a work may be recast, transformed, or adapted."72 In addition, courts have liberally construed the exclusive right of reproduction, holding that it may encompass defendants' works that, while not literally copying or even paraphrasing any of the original's expression, evoke the same "total concept and feel." 73 Given these loose standards, a leading copyright commentator concludes-with good reason-that if Shakespeare's Romeo and Juliet were protected by copyright today, the Broadway musical West Side Story might well be found to infringe it. ${ }^{74}$ Finally, a defendant, such as the creator of a multimedia CD-ROM, who has copied a small portion of a preexisting work and incorporated it as a small portion of his work, may likewise run afoul of the reproduction right in the original. ${ }^{75}$ Under today's rule of "fragmented

68. As Benjamin Kaplan correctly notes, the infringement problem in pretwentieth-century adaptation cases was answered, in contrast to today's approach, "by looking not so much to what the defendant had taken as to what he had added or contributed." BENJAMIN KAPLAN, AN UNHURRIED VIEW OF COPYRIGHT 17 (1967). In fact, eighteenth-century English judges, including Lord Mansfield, generally lauded the defendants' "improvements" as "extremely useful" and "meritorious." Sayre v. Moore, 102 Eng. Rep. 139 (K.B. 1785); Burnett v. Chetwood, 35 Eng. Rep. 1008 (Ch. 1720); Newbery's Case, 98 Eng. Rep. 913 (Ch. 1773).

69. See Stowe v. Thomas, 23 F. Cas. 201 (C.C.E.D. Pa. 1853) (No. 13,514).

70. The 1870 Copyright Act provided that "authors may reserve the right to dramatize or to translate their own works." Act of July 8, 1870, ch. 230, $\$ 86,16$ Stat. 212 (1871). The 1909 Act added the right to make adaptations and other versions of certain types of original works. See Act of March 4, 1909, ch. 320, § 1(b), 35 Stat. 1075, 1075. For a synopsis of the 1909 adaptation provisions, see Paul Goldstcin, Derivative Rights and Derivative Works in Copyright, 30 J. COPYRIGHT SOC'Y USA 209, 214 (1983). The Copyright Act of 1976 expands this right by according authors the exclusive right to prepare derivative works based upon any type of copyrighted work. See 17 U.S.C. \& 106(2) (1994). It defines "derivative work" broadly to include "a translation, musical arrangement, dramatization, fictionalization, motion picturc version, sound recording, art reproduction, abridgment, condensation, or any other form in which a work may be recast, transformed, or adapted." Id. $\$ 101$. For an insightful and detailed discussion of courts" gradual move from a focus on defendants' contributions to a view that copyright owners are generally entitled to control any use of expression from which they might profit, see Lunney, supra note 30 . at $534-40$.

71. See 17 U.S.C. \$ $106(2)$ (1994).

72. Id. $\$ 101$ (definition of "derivative work").

73. Roth Greeting Cards v. United Card Co., 429 F.2d 1106, 1110 (9th Cir. 1970) (holding that defendant's imitative greeting card may be infringing even though it copied neither copyrighted text nor copyrighted artwork).

74. See 3 NIMMER ON COPYRIGHT, supra note 56, \& 13.03[A][1][b], at 13-36.

75. See, e.g., Tin Pan Apple Inc. v. Miller Brewing Co., 30 U.S.P.Q.2d (BNA) 1791 (S.D.N.Y. 1994) 
literal similarity," the defendant's contribution would be deemed irrelevant to the prima facie case of copyright infringement. ${ }^{76}$ In shor, like the producers of West Side Story, T.S. Eliot would today run afoul of copyright were not The Waste Land a pastiche of centuries old material.

As all authorship involves a degree of borrowing from earlier works, ${ }^{n}$ an overly broad copyright represents an unacceptable burden on creative expression. Given this concern, a number of commentators and litigants have asserted that copyright should be subject to First Amendment limitations, principally to ensure that authors may incorporate existing expression as necessary for the critical commentary and expressive diversity upon which democratic governance depends. ${ }^{78}$ Courts have steadfastly rejected First Amendment defenses to copyright infringement claims, for the fundamental reason that copyright doctrine itself is said to contain core limitations on copyright owner prerogatives that more than adequately protect First Amendment values. ${ }^{79}$ Perhaps unwittingly, however, judicial reliance on copyright doctrine to reject First Amendment defenses has resulted in a sleightof-hand. As copyright has evolved, its internal limitations on copyright owner prerogatives have themselves been vitiated by copyright expansionism. As a result, the copyright law safeguards that have made First Amendment defenses seem overly intrusive and unnecessary have in fact been only sporadically effective in protecting First Amendment values. ${ }^{80}$

(declining to hold, as matter of law, that defendant's digital sampling of words "Hugga-Hugga" and "Brr" from plaintiff's song constituted noninfringing copying of noncopyrightable matenal): Jarvis $\vee$. A \& M Records, 27 U.S.P.Q.2d (BNA) 1812, $1817-19$ (D.N.J. 1993) (denying defendani's motson for summary judgment on grounds that genuine issue of material fact existed as to whether sounds and phrases "ooh." "moves," and "free your body" were significant to song from which they were digitally sampled and regarding fact that "[t]he two songs were utterly unlike and reached completely different markets" as irrelevant to question of infringement).

76. See 3 NIMMER ON COPYRIGHT, supra note 56, \$ 13.03(A][2], at 13-49. The modern position regarding the irrelevance of the defendant's contribution was cogently stated by Leamed Hand: "[N]o plagiarist can excuse the wrong by showing how much of his work he did not pirate." Sheldon $v$ MetroGoldwyn Pictures Corp., 81 F.2d 49. 56 (2d Cir. 1936).

77. As Terry Eagleton puts it: "[A]ll poems can be read as rewriungs of other poems." TERRY EAGLETON, LITERARY THEORY: AN INTRODUCTION 183 (1983).

78. See Robert C. Denicola, Copyright and Free Speech: Constitutional Limilations on the Protection of Expression, 67 CAL. L. REV. 283 (1979); Paul Goldstein. Copyright and the First Amendment, 70 COLUM. L. REV. 983 (1970): Melville B. Nimmer. Does Copyright Abrige the First Amendment Guarantees of Free Speech and Press?, 17 UCLA L. REV. 1180 (1970); L Ray Patterson. Free Speech. Copyright, and Fair Use, 40 VAND. L. REV. 1 (1987).

79. See Harper \& Row, Publishers, Inc. v. Nation Enlers., 471 U.S. 539.560 (1985) (explaıning that First Amendment protections are "already embodied in the Copyright Act's distunction between copyrightable expression and uncopyrightable facts and ideas"): Roy Export Co. v. CBS. 672 F.2d 1095. 1099 (2d Cir. 1982) ("No circuit that has considered the question... has ever held that the First Amendment provides a privilege in the copyright field distinet from the accommodatson embodied in the 'fair use' doctrine.").

80. In addition to relying on the safeguards as a whole in dismissing calls to reevaluate the First Amendment copyright relationship. Congress and the courts have approved the erosion of each intemal safeguard in tum, while relying on the other safeguards to take up the slack. See Jessiea Litman. Copyright and Information Policy, LAW \& CONTEMP. PROBS., Spring 1992. 185, 204-06 (1992). 
Copyright doctrine purports to limit the scope of protection, and thus to maintain an acceptable degree of transformative expression and discursive exchange, in three principal ways. First, copyright law limits the duration of protection. Even if the copyright owner's exclusive rights are somewhat onerous, the work will eventually fall into the public domain. As the copyright term gets longer and longer, however, this limitation becomes highly attenuated. Indeed, a copyright term lasting the life of the author plus seventy years would often freeze in place proprietary barriers to public access for a century or more.

Second, copyright doctrine posits a dichotomy between protectible expression and unprotected ideas. While a work's aesthetic form falls within the province of the copyright owner's exclusive rights, the ideas that the work evokes or seeks to convey are free for all to use. ${ }^{81}$ In theory, therefore, even copyright owners' extensive control over "expression" would not constrain the free exchange of "ideas." But while the idea/expression dichotomy makes sense in principle, it is notoriously malleable and indeterminate. ${ }^{82}$ Indeed, much of copyright's expansion into the area of derivative uses of existing works reflects a recharacterization as protected expression of what used to be considered public domain ideas.

Finally, copyright's fair use doctrine provides that in some circumstances even the appropriation of expression will not constitute an infringement. ${ }^{83}$ The application of the fair use doctrine requires a case-by-case analysis of factors, including the purpose and character of the defendant's use, the nature of copyrighted work, the amount and substantiality of the portion used, the effect of the use on the potential market for or value of the copyrighted work, and any other factor that the court may deem appropriate. ${ }^{84}$ Commentators have bemoaned the seeming absence of consistent, principled application of the fair use doctrine. ${ }^{85}$ More significantly, Congress and the courts have narrowed the scope of the fair use privilege, converting it from a standard that left

81. The idea/expression dichotomy is codified in section 102(b) of the Copyright Act, which provides: "In no case does copyright protection for an original work of authorship extend to any idea, procedure, process, system, method of operation, concept, principle, or discovery, regardless of the form in which it is described, explained, illustrated, or embodied in such work." 17 U.S.C. § 102(b) (1994); see also Alfred C. Yen, A First Amendment Perspective on the Idea/Expression Dichotomy and Copyright in a Work's "Total Concept and Feel", 38 EMORY L.J. 393 (1989).

82. As Judge Leamed Hand said, the line between idea and expression "wherever it is drawn, will seem arbitrary." Nichols v. Universal Pictures Corp., 45 F.2d 119, 122 (2d Cir. 1930). As a result, Hand noted thirty years later that "[t]he test for infringement of a copyright is of necessity vague." Peter Pan Fabrics, Inc. v. Martin Weiner Corp., 274 F.2d 487, 489 (2d Cir. 1960).

83. The fair use doctrine is codified at 17 U.S.C. $\S 107$ (1994).

84. See id. The factors set forth in the statute are not exclusive. See Harper \& Row, Publishers, Inc. v. Nation Enters., 471 U.S. 539, 587-88 (1985) (Brennan, J., dissenting); American Geophysical Union v. Texaco Inc., 37 F.3d 881, 886 (2d Cir. 1994).

85. See, e.g., 3 NIMMER ON COPYRIGHT, supra note 56, § 13.05[A], at 3-156 to 3-159 (analyzing fair use factors and concluding that their "infinite elasticity" results in their "inability to resolve difficult questions"); Fisher, supra note 27, at 1668-69, 1692-95 (describing equitable nature of fair use doctrine, but concluding that doctrine as it stands is incoherent). 
considerable room for copying as part of an effort to create a new work to a standard that permits such reuse only in isolated cases. ${ }^{86}$

\section{B. Further Expansion by Contract}

Even to the extent that copyright's internal limitations do preserve a space for personal uses and discursive exchange, copyright expansionists would accord copyright owners an opportunity to circumvent those limitations through digital technology and contract. The revolution in digital technology and computer networks raises the very real possibility that in the not-too-distant future much expression will be available primarily or solely online. A person who buys a book generally has no contractual relationship with the author, publisher, or bookseller regarding how the person may use the book. The buyer's rights to read the book, make notes in it, copy expression or ideas from it, or dispose of it through sale, rent, or gift are all determined by the nature and scope of the copyright owner's exclusive rights in the literary work embodied in the book and the buyer's property rights in book itself. Yet if the same person wishes to access a text that exists only in digital format in an electronic database, he may well have to do so by entering into a subscription contract or other agreement with the database proprietor. In that event, the database proprietor may condition access on the reader's binding promise to refrain from using the text in ways that would constitute a fair use or that would be simply be beyond the limits of the copyright owner's exclusive rights. The database proprietor might also obtain the contractual near equivalent of copyright protection-or more-for texts that are in the public domain. $^{87}$

Similar efforts by computer software manufacturers to include such terms in "shrinkwrap licenses" accompanying hard copies of consumer computer software have generally failed on grounds of copyright preemption or failure of mutual assent. ${ }^{88}$ But the Seventh Circuit has recently upheld the enforceability of such a license, ${ }^{89}$ and there is a move afoot, supported by the NII White Paper, to make them generally enforceable. ${ }^{90}$ Moreover, database access contracts would more closely resemble the standard contractual meeting of the minds than do shrinkwrap licenses and thus might have a greater chance

86. See Lunney, supra note 30 , at 546-52.

87. For a discussion of these phenomena and their potential ramifications, see GolOSTEIN, supra note 21, at 223-34; Jane C. Ginsburg. Copyright Without Walls". Speculations on Literun Propert in the Library of the Future, REPRESENTATIONS, Spnng 1993. at 53. 59-64. Marh A Lemle). Shrunkurups in Cyberspace, 35 JURIMETRICS J. 311 (1995).

88. See Mark A. Lemley, Intellectual Property and Shrmkwrap Licenses. 68 S CAL L REV 1239. 1249-50 (1995).

89. See ProCD, Inc. v. Zeidenberg. 86 F.3d 1447 (7th Cir 1996)

90. An amendment to Article 2 of the Uniform Commercial Code to cover such licenses is under consideration by the Permanent Editorial Board for the Uniform Commercial Code and the amendment is supported by the White Paper. See NII WHITE PAPER, supra note 6. at 58-59 
of surviving the contract law challenges that have until recently thwarted shrinkwrap licenses. ${ }^{91}$ The enforceability of such database access contracts will likely depend on whether they are held void against public policy, given copyright law and First Amendment limits on the private monopoly over expression, or whether their enforcement in state court is held preempted by the Copyright Act. ${ }^{92}$ If the White Paper position is accepted, access contracts that exceed copyright limits would survive such challenges. Touting the efficiency benefits of online licensing, the White Paper argues that state statutes that recognize the validity of "on-line licenses-even those licenses which cover the exclusive rights of the copyright owner-would not usurp Federal power and should be upheld." ${ }^{\prime 3}$

\section{THE NEOCLASSICIST APPROACH TO COPYRIGHT}

There are many reasons for copyright's expansion, including technological development, power politics (both domestic and international), and the transformation of the United States from a net importer to a major exporter of intellectual works. ${ }^{94}$ In combination with these factors, the perceived theoretical justifications for copyright have continued to weigh heavily in decisions of judges, legislators, and policymakers regarding the nature and extent of copyright protection. Naked self-interest can only go so far in shaping the contours of a legal regime. The most robust policy ideas are informed by a cogent thetorical framework that eases their way to general acceptance. ${ }^{95}$ For that reason, competing theories have loomed large in the controversy over copyright's scope. ${ }^{96}$

An approach to copyright based on a blend of neoclassical and new institutional economic property theory has emerged as the principal theoretical

91. See Joel Rothstein Wolfson, Information Transactions on the Information Superhighway: It's Not Just Sofnuare Law Anymore, 6 J. PROPRIETARY RTS., Nov. 1994, at 2, 2-3. But see John B. Kennedy \& Shoshana R. Davids, Web-Site Agreements Do Not Wrap Up IP Rights, NAT'L L.J., Oct. 23, 1995, at C3 (concluding that many current World Wide Web site agreements are probably unenforceable because they are not sufficiently conspicuous and do not require site visitors actively to manifest assent after having opportunity to review license terms).

92. See 17 U.S.C. $\$ 301$ (1994); see also David A. Rice, Public Goods, Privare Contract and Public Policy: Federal Preemption of Software License Prohibitions Against Reverse Engineering, 53 U. PITT. L. REV. 543, 594-95 (1992) (asserting that software shrinkwrap licenses should be preempted).

93. NII WHITE PAPER, supra note 6, at 58-59.

94. Throughout most of the nineteenth century, the United States was a net importer of copyrighted works, primarily books from Great Britain. Largely as a result, the United States did not accord domestic copyright protection to foreign works until Congress enacted the International Copyright Act of 1891, 26 Stat. 1106, and even then it imposed, as a condition for protection, compliance with U.S. registration. notice, and deposit requirements and the American manufacture of "any book, chromo, lithograph or photograph." Id. § 3. Today, however, the United States is the world's largest exporter of copyrighted works. See MARSHALl A. LEAFFER, UNDERSTANDING COPYRIGHT LAW $\$ 12.5$ (1989).

95. See Herbert Hovenkamp. The Marginalist Revolution in Legal Thought, 46 VAND. L. REv. 305 , 308-09 (1993).

96. See generally Symposium, Intellectual Property Law Theory, 68 CHI.-KENT L. REv. 583 (1993) (treating intellectual property law from philosophical, economic, and artistic perspectives). 
support for copyright expansionism. Eminent intellectual property scholars, including the author of a leading copyright treatise, have espoused the neoclassicist approach to copyright. ${ }^{97}$ The approach has animated a line of cases that would dramatically expand copyright owner prerogatives, ${ }^{93}$ and its

97. Stanford Law School Professor Paul Goldsteun's copynght treatise vieu s copy nght pnncupaliy trom an economic perspective and employs neoclassical analysis frequently (although not exclusively, Ser GOLDSTEIN, supra note 18, $\$ 11.14 .2 .3-4$, at 1-51-57 (manntanning that compulson licenses. exemptions. and liability nules that detract from copynght owners' full propeny nghts should be emplosed spanngly. if at all, because of their detrimental effect on owner investment in existing worhs and disnuption ol poicing mechanism by which consumers signal what worhs they want) Professor Goldstein involes the neoclassicist approach more expressly in his recent provocauve and capuvalung account of copy nght's innes workings from Gutenberg to the digital age. See GOLDSTEIN. supro note 21. at 176-79. 217-24. 236

A number of scholars asser that a misguided natural nghts approach. logether with vestiges of nineteenth-century Romanticism, has pushed copynght in the direction of a full common law property nght. a right that is immune to claims of public access. See. e.g. JAMES BOYLE. SHAWASS. SORTWAKE. AVD SPLEENS: LAW AND THE CONSTRLCTION OF THE INFORMATION SOCIETY $51-59$ (19)6). MlakK RUSt. AUTHORS AND OWNERS: THE INVENTION OF COPYRIGiT (1993); Jaszi, supra nole 9. Peler Jass., Tosuard a Theon' of Copyright: The Metamorphoses of "Auhtorship". 1991 Dt'KE L.J iss (hereinafter Jaszi. Toward a Theory]; Litman, supra note 9, at 965-66. see also Gordon. Self-Expression. supru nule 8. at 1540 (pointing finger at misinterpretation of Lockean natural nghts theon) This claun is wholly unconvincing. Aside from an early and sporadic influence. the notion that author afe entutled, as a malte? of natural right, to a reward for their intellectual labor, let alone to a full propnetan nght in thest crestive product, has been rejected repeatedly and in no uncertain terms by both Congress and the courts Ser $r$, Fogerty v. Fantasy, Inc. 114 S. Ct. 1023.1029 (1994) ("We have often recognized the monopuly pnvileges that Congress has authorized, while intended to motuvate the creatuse actuvity of authors and insentors by the provision of a special reward, are limited in nature and must ultumately sene the public good "*, (quoting Sony Corp. v. Universal City Studios. Inc., 464 U S 417.429 (1984)) In addition, esen when the idea of giving a reward to authors is presented as a seconding ratuonale for copsnght, It is stated euther as an inducement to creative production. see, e.g.. United States I Paramount Pictures, Inc . 3.4 C'S 131. 158 (1948) ("It is said that reward to the author or anust serves to induce release to the public of the products of his creative genius."). or as a "farr retum." Harper \& Row. Publishers. Inc 、 Vation Enters. 471 U.S. 539, 545-46 (citing Twentieth Century Music Corp 、Aiken. 122 U's 151. 156 11975i). "commensurate with the services rendered." Mazer v. Steın. 347 U S 201. 219 (1954), a formulation that envisions a limited claim to compensation, not a broad propnelany entullement For a fuller explication of this point, see Marci A. Hamilton, Approprianon Art and the Immenen Declume in Authorul Control over Copyrighted Works, 42 J. COPYRIGHT SOC'Y 93. 98-112 (1994) (arguing that those who assen malenal natural rights/Romanticism influence are "battıng at a straw man"). Neil Netanel. The Lall and Literature Attack on the Law of Literature: Should Copynght Be Deconstructed" (1993) (unpublished manusernpt, on file with author) (arguing that claim of influence of Romanucism on carly and subsequent copynght doctrine is highly exaggerated).

98. The leading case is Harper \& Row: Publtshers. Inc. v Nanon Enterprises. 47 ! L'S 539 (1985) (holding that story in The Nation composed of quotes. paraphrases. and facts urawn exelusively from manuscript by former President Gerald Fond was not fair use under Copynght Acil In that case the Supreme Court in effect recognized, under the rubne of copynght. an expansile propnctary nght to capture the full economic value of the initial release of information. Twice culing to an article in which Protessor Wendy Gordon explicitly laid out a neoclassicist view of copynght and farr use. sec Gordon. Fatr $U_{\text {'se. }}$ supra note 8, the Court ruled that the fair use "exception" would be avalable only in highly carcumsiribed instances of bilateral market failure. See 471 U.S. at 559.566 n 9 Faur use. the Cour stated, is inappropriate unless a "'reasonable copynght owner [would) have consented to the uxe'" given the "importance of the material copied or performed from the point of view of the reasonuble copurthts owner." Id. at 550 (quoting ALAN LATMAN. FAIR USE OF COPYRIGITT WORKS 15 (1958), reprinted in STUDIES ON COPYRIGHT 779 (1963)); see also ProCD. Inc. 1. Zeidenberg. 86 F 30 14t7. 1 4h9 ith Cir 1996) (upholding enforceability of "shrinkwrap licenses" that prosernbe user copying of uncopy nghtable material); American Geophysical Union v. Texaco, Inc., 37 F.3d 881.897-99 (2d Cir 1994) (holding that availability of workable market for joumal-article photocopy licensing through establishment of collectuve licensing organization militates against fair use for unlicensed photocopyng. esen apan from any showing of lost subscription revenue); Salinger v. Random Housc. Inc.. 811 F.2d 90. 99-100 (2d Cir 1987) (holding 
influence is apparent in the NII White Paper's analysis and recommendations. ${ }^{99}$

\section{A. Two Approaches to Copyright Economics}

It is important at the outset to distinguish the neoclassicist approach from the economic incentive rationale for copyright. In addressing the theoretical foundations for intellectual property, courts and commentators often present economic analysis as a single monolithic whole. ${ }^{100}$ The economic analysis of intellectual property, however, encompasses at least two conceptually distinct approaches. ${ }^{101}$ While each approach purports to take wealth maximization and allocative efficiency as its organizing principle, their respective applications of this principle diverge sharply. Most importantly for our purposes, the incentive approach tends to look critically at copyright's expansion, questioning whether greater protection is necessary to provide an economic incentive for the production of creative works. The neoclassicist approach, on the other hand, has pushed economic analysis in the opposite direction. It supports expanded intellectual property rights and a diminished public domain. The neoclassicist approach appears to have gained the upper hand, and now dominates the field of copyright economics.

The incentive approach seeks to explicate intellectual property's traditional incentive rationale in economic terms. Beginning with the Statute of Anne of 1709 , copyright statutes have been based on the unproven intuition that authors and publishers will not make works available to the public unless they can prevent others from making copies, at least for a limited time. ${ }^{102}$ The approach, which dates back to Adam Smith, has generally found justification for this intuition in economic theory. ${ }^{103}$ It posits, along the lines discussed

that author was entitled to protect potential market for his unpublished letters, even though he disavowed any intention to publish them during his lifetime).

99. See supra text accompanying notes 65-67, 90-93.

100. See, e.g., Ralph S. Brown, Eligibility for Copyright Protection: A Search for Principled Standards, 70 MiNN. L. Rev. 579, 596-600 (1985); Fisher, supra note 27, at 1700-04; Alfred C. Yen, Restoring the Natural Law: Copyright as Labor and Possession, 51 OHI ST. L.J. 517, 518 (1990).

101. For a historical account of economic approaches to copyright, see Gillian K. Hadfield, The Economics of Copyright: An Historical Perspective, 38 COPYRIGHT L. SYMP. (ASCAP) 1 (1992). For a brief account of opposing approaches to the economic analysis of the law generally, sec Nicholas Mercuro \& Steven G. Medema, Schools of Thought in Law and Economics: A Kuhnian Competition, in LAW AND ECONOMICS: NEW AND CRITICAL PERSPECTIVES 65 (Robin Paul Malloy \& Christopher K. Braun eds., 1995).

102. See An Act for the Encouragement of Learning, by Vesting the Copies of Printed Books in the Author's or Purchasers of Such Copies, During the Times Therein Mentioned, 1709, 8 Anne, ch. 19 (Eng.).

103. Adam Smith lauded the temporary monopoly granted to authors and their assigns under the Statute of Anne as an efficient means of stimulating book production: "[I]f the book be a valuable one the demand for it in that time [i.e., the copyright period] will probably be a considerable addition to his [i.e., the author's] fortune. But if it is of no value the advantage he can reap from it will be very small." Adam Smith, Lectures on Jurisprudence; Report of 1762-63, in ADAM SMITH, AN INQUIRY INTO THE NATURE AND CAUSES OF THE WEALTH OF NATIONS 754 n.69 (R.H. Campbell \& A.S. Skinner eds., 1976) (1776). 
in Part I, that copyright is necessary to prevent free riders from undermining the market in creative expression. This support has usually been qualitied. however, by a concern for copyright's social cost. Incentive theorists emphasize that copyright carries with it some of the problems of monopoly pricing, and they question the desirability of expanding copyright beyond the minimum necessary to provide authors with an incentive to produce. ${ }^{\text {is }}$

Neoclassicists label the incentive approach "crude" and "twodimensional." 105 They do not deny that copyright may serve as a necessary production incentive, but in their eyes copyright is much more. Under the neoclassicist approach, copyright is primarily a mechanism for market facilitation, for moving existing creative works to their highest socially valued uses. Copyright can best serve this goal, neoclassicism suggests, by enabling copyright owners to realize the full profit potential for their works in the market. ${ }^{106}$ In maximizing their profit, neoclassicists argue, copyright owners will both rationalize the "development" of existing creative works and sell exploitation entitlements to those who are best able to satisfy public tastes. ${ }^{107}$ For neoclassicists, copyright enables owners to charge users for access to creative work public goods not so much to preserve author incentives as to determine what creative works are worth and thus to create a guide for resource allocation. ${ }^{108}$

Accordingly, the neoclassicist approach focuses less on the precarious balance between reader and writer than on perfecting markets for all potential uses of creative works for which there may be willing buyers. While the incentive approach sees copyright as a limited grant, neoclassicists envisage a regime of broad, fully exchangeable property rights in creative products, with

104. See, e.g., Sterk, supra note 30 , at 1204-08

105. See, e.g., Wendy J. Gordon, An Inquiry into the Meruts of Copiright The Challenges of Consistency, Consent, and Encouragement Theon, 41 STAN. L. REV. 1343, 1435-19 (1989) (argung that economic approach to copyright that points to "author's entitlements as the starung point from which markets evolve" is superior to one that asks whether copynght incenuve is necessan to provide consumers with works they would otherwise not have): Rober P. Merges, Are You Making Fun of Me "Notes on Market Failure and the Parody Defense in Copyright. 21 AIPLA QJ 305. 306 (1493) (noung that economic literature on copynght has "progressed beyond the point where a crude "Incentuse" story passes for analysis in every case"): Roben P. Merges \& Richard R. Nelson. On the Complet Economucs of Puten Scope, 90 CoLUM. L. REV. 839, 842 (1990) (statung that newer economic approach to patent gues far "beyond the two-dimensional analysis of incenuves and deidueight loss")

106. See GoldSTEIN, supra note 21, at 236.

107. See, e.g., Gordon, supra note 105, at 1393; see also Robert C Denicola. Institutional Public in Rights: An Analysis of the Merchandising of Famous Trade Symbols. 62 N C L REV 603.637-11 (198-4) (arguing that trademarks serve to organize efficiently development and exploitation of existing inventions). Edmund W. Kitch. The Nature and Function of the Patent System. 20 J.L. \& Ecov 265 (1977) (applying similar analysis to patents).

108. For neoclassicists, therefore, intellectual property is less about creating an artitictal searctiy in intellectual creations than about managing the real scarcity in the other resources that may be employed in using, developing, and marketing intellectual creations. See Kutch. supra note 107, at 275-76. ser alsu 1 HAROLD DEMSETZ, OWNERSHIP, CONTROL AND THE FIRM: THE ORGANIZATION OF ECONONIC ACTIVIT 39 (1988) (discussing valuation-of-resource-use ratıonale for requinng payment for use of publıc good) Demsetz, supra note 25 , at $295-96$ (same). 
the goal of achieving allocative efficiency. ${ }^{109}$ While incentive theorists struggle to find just the right amount of copyright protection required to give an adequate production incentive, neoclassicists eschew such policymaking uncertainty in favor of assigning copyright owners maximum rights and leaving the allocation of those rights up to the market.

The neoclassicist approach, in essence, justifies allowing copyright owners to garner monopoly rents on the grounds that doing so will, through the pricing system's capacity to signal consumer preferences, enable copyright owners to develop and market expressive works in ways that consumers want. Aside from the dubious economic premises of this argument, ${ }^{110}$ the neoclassicists' baseline vision of a broad, absolute copyright gives rise to an increased danger that blatant copyright owner censorship and an overly burdensome tax on users will inhibit expressive diversity and the advancement of knowledge.

To be certain, neoclassicist copyright scholars are generally mindful that market dictates will sometimes conflict with copyright's democracy-enhancing goals. "II Indeed, most of those whom I have, for ease of reference, labelled "neoclassicists" have, on some occasions, considered nonmarket values and approaches as well. But as I will show, when these scholars have advanced a neoclassicist approach, their attachment to the market paradigm has ultimately frustrated their efforts to account for copyright's democracy-enhancing goals.

Moreover, and herein lies the true danger, courts and policymakers who have adopted the neoclassicist paradigm have generally overlooked the more nuanced, contextualized account that thoughtful scholars have sought to advance. ${ }^{112}$ As in other areas of the law, neoclassicism has exhibited a

109. I have found only two intellectual property scholars who have noted the propensity of neoclassicist economics to support a broad proprietary copyright akin to that which might result from a belief that authors deserve exclusive control over their creations as a matter of natural right. See GOLDSTEIN, supra note 21, at 178-79; Hadfield, supra note 101, at 41-46.

110. The neoclassicists' economic premises are faulty in at least two basic respects. First, as Glynn Lunney and others have pointed out, assuming the efficacy of the pricing system model, a broad proprictary copyright may well lead to the mix of expression that consumers of expression prefer, but it would draw resources away from nonexpressive productive activity, thus resulting in an inefficient allocation of resources overall. See infra text accompanying notes 255-57. Second, as numerous studies have shown, there are significant discrepancies between the pricing system model and markets' actual operation. See infra text accompanying notes 241-48.

111. See infra text accompanying notes 188-91.

112. A prime example is the Supreme Court's decision in Harper \& Row. Publishers, Inc. v. Nation Enters., 471 U.S. 539 (1985), relying, at least in part, on Wendy Gordon's neoclassicist analysis of fair use. See supra note 98 . In that analysis Gordon sought to argue that consumptive uses, not just transformative uses, may sometimes qualify for fair use. See infra note 228 and accompanying text. In presenting her argument in neoclassicist terms, however, she imposed restrictive conditions on fair use, positing that it should be available, at least in the absence of fundamental, overriding nonmonetizable interests, only when the defendant proves that the market failure is insurmountable, that transferring control over the use would serve the public interest, and that the copyright owner's incentives would not be substantially impaired. See infra notes 229-33 and accompanying text. Picking up on Gordon's neoclassicist market model and the restrictive conditions that flowed from it, the Supreme Court denied fair use to The Nation's transformative use of some 300 words from President Ford's memoirs over strident objections from the dissent that the Court was recognizing a proprietary right of public officials "to capture the full economic value of information in [their] possession." thus stifling "the robust debate of public issues that is the 'essence of 
powerful allure. Its rarified price system model promises a seemingly hermetic and simple framework for mechanically resolving fundamental tensions between competing values and interests. ${ }^{113}$ But as we shall see in the case of copyright, the neoclassical model both sidesteps the persistent iregularities of real world markets and errantly reduces complex issues of public policy to readily assessable bilateral transactions, glossing over intractably external social benefits and costs of market actor decisions.

\section{B. The Neoclassicist Approach}

The neoclassicist approach has roots in late nineteenth-century marginal utility theory. Marginal utility theory represented a fundamental shift from the classical conception of property as the embodiment of previously committed investment and labor to an identification of property with the ability to capture future profits. ${ }^{114}$ Its emergence coincided with, and appears to have contributed to, early extensions of copyright's scope. ${ }^{115}$ Neoclassicism has ascended to prominence during the last three decades-a period of marked intellectual property expansion-with the Chicago school's application of

self-govemment." Harper \& Row, 471 U.S. at 591 (Brennan, J. dissentung) (citation ormitted) With potentially far-reaching implications, the Cour ruled as well that far use should be avalable only in isolated cases of market failure and in the absence of any adverse effect on the potentual market for the copyrighted work not only from the use in question, but also from others like it. See id at 5.49-50. 568

113. Neoclassical scholars purport to recognize that the pnce system model is only that a model that. because it provides a simplified account of social reality, may be a relatively workable predictuve tool for a limited universe of issues. See, e.g., GEORGE j. STIGLER. THE THEORY OF PRICE S (3d ed 1966) ("Clearly a general theory must ignore a thousand detailed vanatıons or $t$ cannol possibly be general Yet only general theories are useful."); see also Herber Hovenkamp. Posirsism in Law \& Economics. 78 C AL L. REV. 815, 817 (1990) (noting neoclassical law and economics" posituvist predisposition tow ard "stnppeddown models that account for few of the world's facts but have greal predictuve power, over complex models that account for everything but make prediction difficult"). The problem is that this limitation is too often relegated to the margins when scholars employ the pnce system model to analyze complex realworld public policy issues. That tendency is exacerbated, moreover. when policymakers and laumakers. faced with the daunting task of making decisions regarding complex and often controversial issues. see the model as a simple, value-neutral tool for enabling them to do so. See Michael S. Jacobs. An Essas on the Normative Foundations of Antitust Economics, 74 N.C. L. REV. 219. 237-38 (1995) (discussing attraction of neoclassical price theory's seeming coherence. ease of applicability, and value-ncutralıty to courts addressing antitrust issues). Numerous commentators have underscored the methodological shontcomings and implicit normative posture of neoclassical law and economics and the pnce system model Sec. $<\mathrm{g}$. MARK KELMAN, A GUIDE TO CRITICAL LEgAL STUDIES $114-85$ (1987) (canvassing cnlqques by CLS and other scholars); C. Edwin Baker, The Ideology of the Economic Analysis of Law, 5 PuIL \& PL B AFF 3. 4 (1975) (noting methodological inconsistencies and conservatuve ideology in Chicago school of law and economics); J.M. Balkin, Too Good To Be True: The Posutwe Economic Theon of Law, 87 CoLl i L REV. 1447, 1454 (1987) (noting conservative ideology in Chicago school of law and cconomics) .My primary focus in this Article will be on how neoclassicism supports an expanded copynght. not on the more general issues surrounding neoclassical law and economics.

114. See Hovenkamp, supra note 95, al 324-25.

115. The late nineteenth and early twentieth centuries saw the conversion of copsnght from a mere right to prevent literal or near literal copies to a set of exclusive nghts that included the nght to make adaptations of a work in other languages or media. The notion that propeny nghts could attach to the interest in fully developing and exploiting the markel value of an underlying assel appears to have supported this development. See Netanel. supra note 97, manuscnpt at 29-30. 32. 34. 
economic analysis to legal institutions. ${ }^{116}$ Neoclassical economics views a system of universally applied and clearly defined property rights as a cornerstone of market efficiency. As we shall see, it is the neoclassical sense of allocative efficiency, with its reification of claims to market potential, its emphasis on universal, concentrated, exclusive, and exchangeable property rights, and its subordination of law to market ideals that helps to spur copyright's untoward expansion. ${ }^{117}$

The neoclassicist approach to copyright also borrows from new institutional economic theory. ${ }^{118}$ New institutional economic theorists often place themselves apart from neoclassical law and economics. In particular, they criticize the neoclassical tendency to rely on formal models that treat economic agents (including individuals and firms) as rational maximizers, willing to pursue consistent ends by efficient means. ${ }^{119}$ In addition, where neoclassical models tend to treat transaction costs as exogenous and relatively circumscribed impediments to ideal market exchange, ${ }^{120}$ new institutional theorists emphasize the centrality of transaction costs, and view the desire to

116. See generally R.H. Coase, Law and Economics at Chicago, 36 J.L. \& ECoN. 239 (1993). For a brief discussion of the intellectual property expansionism in recent decades, see Gordon, supra note 6, at 151-52.

117. The inclusion of copyright within the post-Coasean neoclassical umbrelia began with Harold Demsetz's landmark essay setting forth the basic tenets of neoclassical property theory. See Harold Demsetz, Toward a Theory of Property Rights, 57 AM. ECON. REv. PAPERS \& PROC. 347 (1967). Demsetz sought to demonstrate in that essay that property rights arise in conditions of resource scarcity to internalizc the externalities associated with excessive use and to facilitate transfers to the most efficient users by reducing negotiating costs. As such, claimed Demsetz, property rights serve to ameliorate the inherent inefficiencies in common ownership of scarce resources. Toward the essay's close, Demsetz argued that copyright serves a similar function. See id. at 359. Intellectual property, asserted Demsetz, exists in order to intermalize the positive externalities of creating intellectual works. By according property rights in such works, copyright and patent concentrates the social benefits of original expression and invention in authors and inventors, giving them a greater incentive to engage in creative activity. See $i d$. In addition to reworking copyright's traditional incentive rationale in neoclassical terms, Demsetz maintained that marketable rights in intellectual property enable the extemal effects of new creations on existing works to be internalized as well. When a new creation makes an old one obsolete or more valuable, those effects "can be called to the attention of the originator of the new [creation] through market negotiations." Id. All such "problems of externalities," Demsetz concluded, "are closely analogous to those which arise in the land ownership example." $I d$. For a further attempt to justify intellectual property rights within the framework of economic property rights theory by analogizing such rights to ownership in land and the privatization of the commons, see Roger E. Meiners \& Robert J. Staaf, Patents, Copyrights, and Trademarks: Property or Monopoly?, 13 HARV. J.L. \& PUB. POL'Y 911, 916, 919, 923 (1990).

118. For a comprehensive survey of new institutional economic theory, see THRAINN EGGERTSSON, ECONOMIC BEHAVIOR AND INSTITUTIONS (1990).

119. See, e.g., DOUGLASS C. NORTH, INSTITUTIONS, INSTITUTIONAL CHANGE AND ECONOMIC PERFORMANCE 3 (1990) (describing inadequacy of neoclassical model in explaining economic performance outside of markets in developed countries); OLIVER E. WILLIAMSON, THE ECONOMIC INSTITUTIONS OF CAPITALISM 45 (1985) (critiquing neoclassical faith in pricing to bring about optimal resource allocation, arguing that far more attention needs to be paid to institutional dynamics, bounded rationality, and other factors that hinder utility maximization); Eirik G. Funubotn \& Svetozar Pejovich, Property Rights and Economic Theory: A Survey of Recent Literature, 10 J. ECON. LIT. 1137, 1138, 1146-53 (1972) (surveying shift from viewing firms as single profit-maximizing units to studying them as complex organizations composed of utility maximizing individuals).

120. See, e.g., POSNER, supra note 32, at 51 (maintaining that ideal Coasean bargaining is possible "whenever the transaction cost is less than the value of the transaction to the parties"). 
reduce them as a driving force behind economic organization and legal institutions. ${ }^{121}$

Whatever their differences, however, for our purposes new institutional economic property theory is more of a supplement than a rival to its neoclassical counterpart. Like their neoclassical counterparts, new institutional theorists posit that broad, clearly defined property rights are desirable for economic efficiency. ${ }^{122}$ In fact, while neoclassical analysis has shied away from property rule norms where high transaction costs would prevent market exchange, new institutional theorists assert that property rules may be desirable even in such cases because property rules are said to induce market actors to establish institutions that will reduce transaction costs. ${ }^{123}$ Like neoclassical law and economics, new institutional property theory also tends to elevate market exchange over the implementation of public policy through law. ${ }^{124}$ In particular, new institutional theorists view property rights as more the product of private arrangement and negotiation than of legislative efforts to further fundamental social goals. ${ }^{125}$

I cannot, within the scope of this Article, do justice to the complexity and intertwined relationship of neoclassical and new institutional economics. Indeed, especially since the neoclassicist approach to copyright draws upon those aspects of new institutional economics that are supplemental rather than rival to the neoclassical school, I will not attempt further to extricate one school from the other. Rather, I will refer to the amalgam of neoclassical and new institutional property theory as "neoclassicism."

121. For a salient, in-depth analysis of how the dnic to economize transuctuon costs has shaped legal and economic institutions, see WILLIAMSON, supra note 119

122. See EGGERTSSON, supra note 118. at 326-27 (asserting that broad. clearly defined. and readily transferable propenty righis are critical to economic prospenty). GARY D LiBECAP. CONTRACTIMG FOR PROPERTY RIGHTS 1 (1989) (stating that focus of property nghis institutions literature "largely has been on how various property rights arrangements affect behavior. which ranges from the wasteful practuces associated with open-access or common pool settings to the " ealth-maxumizing actons posstble with secure private propeny rights").

123. Compare Guido Calabresi \& A. Douglas Melamed. Propern Rules. Lubulun Rules and Inalienability: One View of the Cathedral. 85 HARS L RE 1089. 1106 (1972) (arguing that high transaction costs militate towards luability nule rather than propeny rule). whh James E Kner \& Siewan J. Schwab, Property Rules and Liabiling Rules: The Cathedral in Another Lght, $70 \times \mathrm{YC}$ L. REY 4.40. 464 (1995) (maintaining that judicıal refusal to intervene by way of damages when market negotiations ta!! would encourage parties to learn how to reduce iransaction costs)

124. See Furubotn \& Pejovich, supra note 119. at 1157. sce also Jatobs, supra note 113. at 222 (noting that, whatever their differences. Chicago school and new instututional economits theonsts "[b]oth agree that economics is "the essence of antutrust' and that protecting consumer welfare. concelred in allocative efficiency terms, should be the exclusive goal of competition law") (quoting Jonathan B Baker. Recent Developments in Economics That Challenge Chrcago School liews. 58 AvTrmu ST LI 645. 6-16 (1989)).

125. See, e.g., LIBECAP, supra note 122. al 11 (defining process of defining and adjustıng property-asrights as "contracting" for property rights and as including both private barganning and lobbying efforts)

126. What I have labelled "neoclassicism" is often referred to in the economic litcrature as "property rights theory." See, e.g., Furubotn \& Pejovich, supra note 119 I have chosen my tabel in order to emphasize the approach's roots in neoclassical (or "Chicago school") lau and economics and to distinguish it from natural law approaches that contend that authors hase an inherent propenty nght in their creations The latter distinction is particularly important because many commentaton have erroneously altsbuted 


\section{Neoclassicist Property Theory and Its Application to Copyright}

The nature and scope of a property rights system are not etched in stone. Private property rights may extend to some resources and not others and may encompass varying degrees of exclusivity, enforceability, transferability, and rights of action over physical and intangible goods. The neoclassicist conception of property reflects neoclassicist perceptions of property's central role in promoting allocative efficiency. ${ }^{127}$ In neoclassicist theory, property rights are fundamental to market formation and operation. They enable (or induce) market actors to reduce negotiation costs and internalize externalities. ${ }^{128}$ They also play a vital part in the valuation of resources through the pricing system, purportedly leading to the allocation of those resources to their highest valued uses. ${ }^{129}$ But property rights can only serve these functions if they are relatively broad and clearly defined..$^{130}$ More particularly, given the neoclassicist understanding of property's role in promoting allocative efficiency, neoclassicists tend to favor a general conception of private property rights as universal, concentrated, exclusive, and transferable. ${ }^{131}$ As neoclassicists will readily admit, no entitlement will ever fully embody these attributes. ${ }^{132}$ But the attributes nevertheless remain a baseline standard for neoclassicist property theory and its application to copyright.

\section{a. Universality}

Given the inherent inefficiency of the public domain in the neoclassical scheme, neoclassicists posit that, ideally, all scarce resources should be owned, or ownable, by someone. ${ }^{133}$ Scarce resources that are not subject to

copyright's expansion to the vestiges of an authors' property rights theory based in Lockean natural law and Romanticism. See supra note 97.

127. For a succinct survey of neoclassicist property theory literature, see Louis De Alessi \& Robert J. Staff, Property Rights and Choice, in LAW AND ECONOMiCs 175 (Nicholas Mercuro ed., 1989); Furubotn \& Pejovich, supra note 119. Seminal examples of neoclassicist property theory include YORAM BARZEL. ECONOMIC ANALYSIS OF PROPERTY RIGHTS (1989); POSNER, supra note 32, at 31-85; Demsetz, supra note 117.

128. See Demsetz, supra note 117 , at $355-58$.

129. See Furubotn \& Pejovich, supra note 119, at 1141.

130. See id. at 1141, 1144-45; cf. Carol M. Rose, Property and PERSuAsion: Essays on the HISTORY, THEORY, AND RHETORIC OF OWNERSHIP 209-10 (1994) (discussing some commentators' marketoriented preference for "crystalline specifications of [property] rights" over "muddy doctrines," which "unduly obfuscate commercial transactions").

131. "Universal" means that, ideally, all economic value should be subject to rights of private property. "Concentrated" means that all rights in a given resource are best held by a single owner. "Exclusive" means that the owner may generally, at his sole discretion, prevent others from using the resource. "Transferable" means that the owner's ability to market resource uses is essential to the owner's right of property.

132. See, e.g., BARZEL, supra note 127 , at 2-4, 64-67.

133. See POSNER, supra note 32, at 34; Demsetz, supra note 117. 
individual control are, in effect, deprived of their social value. " Such resources may be used, but they will necessarily be used in ways that neither reflect nor enhance their social value. This is in part because social value is defined tautologically in terms of the price that a purchaser would pay to put a resource to a given use. It also reflects the neoclassical assumption that ownerless resources will be exploited without regard to the externalities arising from their use. ${ }^{135}$

The criterion of universal ownership applies not just to each resource in gross, but to every conceivable aspect, attribute, and use that people value with respect to that resource. Unless owners realize the full potential value for their property on the market, some use of that property will not be moved to its highest value. To the extent that a resource's owner does not or cannot exert exclusive control over a given use of the resource, that use effectively falls into the public domain and its value is lost. For example, if landowners have no right to exclude low-flying aircraft, then neither landowners nor airlines will take the social value of the land's noise-sensitive uses into account in their respective resource allocation decisions. ${ }^{136}$ Likewise, since most restaurants seldom charge an additional price for eating at peak hours or for the time a customer spends at the table, customers who might value those uses more highly cannot acquire them and the uses are thus allocated inefficiently. ${ }^{17}$ Significantly, the criterion of universality applies as well to future uses of a resource. As Richard Posner argues, speculation regarding the possible value of future uses is an integral part of a price-based system of efficient resource allocation. ${ }^{138}$ Accordingly, ownership should generally include the right to hold a resource without using it or to sell at present the right to use the resource at some future time. As a general rule, therefore, neoclassicism strongly favors a regime in which all economic value is subject to rights of private property. ${ }^{139}$

Applying the universality principle to copyright, neoclassicists argue that, absent incurable market failure, the holder's exclusive rights should encompass the economic value of all uses to which an author's work is curtently put or may be put in the future. ${ }^{140}$ Neoclassicists maintain that copyright should

134. See BARZEL, supra note 127 , at 71 .

135. See, e.g., Demsetz, supra note 117, at 356

136. This is not to say that according a nght to exclude low overflights would necessurnly be the most efficient result in our posituve transaction cost world. Where ming landownen afe in the thight path. As would be the case near any urban airpon, each landowner who could exclude the areralt would have an incentive to act as a holdout and thus the arline would be unable to buy the nght See Posver, supra note 32 , at $64-65$.

137. See BARZEL, supra note 127, at 66-67. To some extent, of course, the need for custorners to wast for a table at peak hours is tantamount to paying a pnce for calung at that ume

138. See POSNER, supra note 32 , at $47-48$.

139. Transaction costs, holdout problems, and strategic bargaıning may miltate aganst application of this ideal in many situations.

140. The economic value of authors expression lics in a my nad of potential consumpave and transformative uses. A motion picture may be screened in a movie thealer, vewed on television lvia off.air 
lend blanket support to owner ability to engage in price discrimination among various users, so that owners can obtain their full complement of consumer surplus. ${ }^{141}$ A copyright owner, for example, might not only require a payment each time a work is accessed online, but might also charge different users different amounts for the same use, relying on consumer profiles to exact a greater amount for those uses and types of works that an individual consumer values the most. ${ }^{142}$

Similarly, neoclassicists contend that authors who use existing expression transformatively in creating new expression should generally also have to pay full market price for this use. ${ }^{143}$ They argue that copyright's proprietary entitlement should extend to such derivative works, even as they admit that the derivative right is generally unnecessary to enable authors and publishers to recover their fixed costs in connection with the original work. ${ }^{144}$ According to the neoclassicist market model, those who hold such a broad proprietary right will invest in original works that can be most readily developed into derivative works that consumers want, like novels that are especially wellsuited to screen adaptation or motion pictures with characters that can readily be spun off into merchandise. ${ }^{145}$

Significantly, parallel to Posner's characterization of speculation on future value as an integral component of proprietary entitlement, neoclassicists also maintain that a copyright owner's unwillingness to license a particular use in order to serve long-term business goals is no reason to accord others a right of access. ${ }^{146}$ For neoclassicists, copyright must enable owners to coordinate

broadcast, cable transmission, or video cassette), shown at a school, or, in the not 100 distant future, accessed online through a computer network. The motion picture may also serve as the basis for sequels, novelization, dramatization, television series, character merchandising, parody, and critique.

141. See GolDSTEIN, supra note 21, at 178-79; see also Demsetz, supra note 25, at 302 (maintaining that price discrimination in markets for public goods like television programs is consistent with perfect competition, whereas it is not with private goods).

142. See supra note 30.

143. See, e.g., Gordon, Fair Use, supra note 8, at 1634, 1640-41. By "full market price" I refer to an ex ante price negotiated with the copyright owner, as opposed to a compulsory license or ex post damage award based on administrative or judicial determination of harm.

144. See, e.g., William M. Landes \& Richard A. Posner, An Economic Analysis of Copyright Law, 18 J. LEGAL STUD. 325, 354 (1989). But cf. GoLDSTEIN, supra note 18, $\$ 5.3$, at 5:79 ("Derivative rights enable prospective copyright owners to proportion their investment to the returns they hope to receive not only from the market in which their work will first be published, but from other, derivative, markets as well.").

145. See, e.g., GOLDSTEIN, supra note 18, § 5.3, at 5:79; Gordon, Fair Use, supra note 8, at 1605-06.

146. See, e.g., Gordon, Fair Use, supra note 8, at $1628 \mathrm{n} .151$ (asserting that out-of-print status of work should not generally justify uncompensated fair use where that might injure copyright owner's future market for second printing); id. at 1634 (stressing that "refusals to grant permission to license should ordinarily be honored"). In those cases in which the copyright owner chooses not to license for "noneconomic reasons," such as out of a desire to avoid criticism or parody, Gordon suggests that fair use should be available, since in those cases it is unlikely that a license will ever be available on the consensual market. See id. at 1633; see also Salinger v. Random House, 811 F.2d 90, 99 (2d Cir. 1987) (finding harm to possible future market for unpublished letters even though author had no present intention to publish them during his lifetime); Meeropol v. Nizer, 560 F.2d 1061, 1070 (2d Cir. 1977) ("The fact that the Rosenberg letters have been out of print for 20 years does not necessarily mean that they have no future market which can be injured."). 
product development and to determine investment timing as well as investment direction. ${ }^{147}$ Only in that manner, they contend, will copyright owners exploit authors' expression in a manner that best maximizes social welfare, as measured by the satisfaction of prevailing consumer tastes. ${ }^{148}$

\section{b. Concentrated Ownership}

While the universality principle requires that all scarce resources be owned by somebody, the neoclassical principle of concentrated ownership favors the concentration of all incidents of ownership in any given scarce resource in a single person. Neoclassicists posit that divided ownership is inherently inefficient because it requires coordination and negotiation to insure that each owner develops his share of the resource without interfering with or detracting from the value of the remaining attributes. ${ }^{149}$ As Richard Epstein puts it:

The usual articulation of common-law rules-that ownership entails with it possession, use, and disposition-is an effort to overcome the problem of subsequent transactions costs by giving a single person the control over all relevant aspects of a single thing. The assignment of these three rights to a single person thus prevents the bargaining breakdown that could arise if one person were entitled to exclusive possession of land or chattels that only another person could sell. ${ }^{\text {1so }}$

Like the other neoclassicist principles, the single owner paradigm is not absolute. Among other things, it is in tension with the notion of specialization, the idea that efficiency is best served when each resource attribute is

147. See. e.g., Landes \& Posner, supra note 144, at 354-55 (claiming that denvatue nght enables owner to control timing of publication).

148. See Gordon, Fair Use, supra note 8, at 1605-06. Trotter Handy adds yet another dimension to the notion that a broad proprietary copyright is justified by the need to reduce negoliatung costs See generally Hardy, supra note 3. Professor Hardy notes that as part of the copynght law revision process. Congress has, over the years, held frequent and prolonged heanngs and has taken the testumony of numerous government officials, experts, and interested persons These hearings have led Congress to enatet various limitations and exceptions to copyright owners' exclusive nghts. See id. manusenpt at 50-55 Hardy views these limitations and exceptions as a form of group ownership. akin to the communal ownership of land that Demsetz cites as inherently inefficient. See id. manuscript at 50; see also Demsetz, supra nole 117 , at 350-58. Taking a cue from the neoclassicist charactenzation of the legislatuve arena as an extension of the market, Professor Hardy then argues that congresstonal efforts to hear different interest groups and viewpoints represent "the massive transaction costs of group ownership of copynght property" Hardy. supra note 3, manuscript at 53. Finally, building on Demsetz's view that private property regimes serve largely to overcome the transaction costs of getting large groups to agree on the disposition of common resources, Hardy recommends that rights in informational works should be "pnvatized "See id manuscript at 60. By "concentrating more of [such rights] in the hands of authors." he asserts. "the number of copyright stakeholders could be greatly reduced and group ownership cosis greatly lessened " Id

149. See. e.g., BARZEL, supra note 127. at 86: POSNER, supra note 32. at 66. 71

150. Richard A. Epstein, Holdouts, Externalities. and the Single Owner One Mare Salute to Ronald Coase, 36 J.L. \& ECON. 553, 562-63 (1993). 
transferred to the person who can best exploit it. ${ }^{151}$ But at least as a starting point, single ownership remains the neoclassicist ideal.

The single owner paradigm has been highly influential in the neoclassicist approach to intellectual property. In an often cited early article, Edmund Kitch argued that patent law serves not so much as an incentive to invention, but as a prospect system, that, like a regime of mineral claims, enables the first comer to manage subsequent investment in developing the resource. ${ }^{152}$ Because a patent holder holds an exclusive right to his claim, anyone who wishes to improve the invention or to invest in increasing its commercial value will have to deal with the patent holder. As a result, the patent holder is in a position "to coordinate the search for technological and market enhancement of the patent's value so that duplicative investments are not made and so that information is exchanged among the searchers."153

Copyright has traditionally been of much narrower scope than patent, in part reflecting the idea that our strong interest in expressive diversity overrides any possible efficiency advantage in giving one person broad control over all transformative uses of an existing work of authorship. ${ }^{154}$ But neoclassicists have argued that all incidents of copyright ownership should be concentrated, at least as an initial matter, in a single owner in order to promote economically rational management of expressive resources. Wendy Gordon argues, for example, that concentrating rights in copyright owners requires prospective users to bargain with them. ${ }^{155}$ A more diversified rights structure would impede the development of a licensing market because, to the extent that

151. See BARZEL, supra note 127, at 86; cf. ARMEN A. ALCHIAN, ECONOMIC FORCES AT WORK 143 (1977) (emphasizing that possibility of specialization is primary advantage of private ownership over public).

152. See Kitch, supra note 107, at 265-66; see also Wendy J. Gordon, Asymmetric Market Failure and Prisoner's Dilemma in Intellectual Property, 17 U. DAYTON L. REv. 853, 855 n.13 (1992) (citing Kitch for proposition that copyright may be necessary, even when authors would create without economic incentive, "to facilitate or organize post-creation dissemination of the work").

153. Kitch, supra note 107 , at 276.

154. Kitch's prospect model, in which control over product development is concentrated in a single owner, is also of doubtful efficacy as applied to patents. As Mark Lemley points out: "Expecting one party-original inventor or not-to perfectly identify the potential uses of a new invention, how it might be improved, and who can best improve it is simply not realistic." Lemley, supra note 42 , manuscript at $68-69$.

155. See Wendy J. Gordon, Of Harms and Benefits: Torts, Restitution, and Intellectual Property, 21 J. LEGAL STUD. 449, 472-73 (1992). Interestingly, in another article, which approaches intellectual property more from the perspective of moral norms than neoclassical economics, Gordon suggests that Kitch's prospect model may be inappropriate to copyright since "central control would unduly inhibit creative adaptations." Gordon, supra note 6, at 247. Paul Goldstein favors giving copyright owners broad derivative rights but has suggested that the Copyright Act should not deprive infringing derivative authors of a separate copyright in their additional creative efforts, as that diminishes their incentives to create new works based upon copyrighted materials. See Goldstein, supra note 70, at 239-52. I would submit that, by making unauthorized derivative works an infringement and subjecting infringing derivative authors to property rulc damages and injunction, the Copyright Act so substantially impairs such derivative authors' incentive to create such new works that depriving them of their own copyright, while probably overkill, has little additional incentive-impairing effect. For a further discussion of the balance of incentives between existing work owners and derivative authors, see infra Section V.D. 
prospective users have rights to use existing works, owners who wish to prevent such uses would be faced with the considerable difficulty of identifying and locating the potential users in order to purchase their rights. ${ }^{156}$ William Landes and Richard Posner similarly justify, as necessary to reduce transaction costs, vesting in each author the exclusive right to make any and all derivative works based on her underlying works. ${ }^{157}$ Concentrating exploitation rights in a single person facilitates market formation, they claim, because in that event potential derivative authors avoid having to deal with multiple holders of different rights. ${ }^{158}$

\section{c. Exclusivity}

Neoclassicists generally favor property rules, defined as the absolute right to exclude nonpurchasers from using a resource, over so-called "liability" rules, which allow nonpurchasers to use the resource by paying the entitlement holder an amount set by an organ of the state rather than the parties themselves. ${ }^{159}$ For neoclassicists, private entitlements can best promote allocative efficiency when would-be users must pay the price agreed upon by the entitlement holder in a voluntary exchange. ${ }^{160}$ Accordingly, they argue, the law should impose liability rules only when transaction costs are so intractable and so great that voluntary exchange is highly impractical. ${ }^{161}$ Moreover, in determining whether a nonpurchaser has infringed the owner's property rights, courts should not generally take into account whether the owner suffered any harm from the unauthorized use or whether the use resulted in socially beneficial effects. Rather, the owner should be entitled to monetary as well as injunctive relief simply upon a showing of unauthorized use. ${ }^{162}$ Otherwise, neoclassicists contend, the cour will be usurping the owner's proprietary entitlement to determine the terms upon which use rights may be purchased. ${ }^{163}$

156. See Gordon, supra note 155 , at $472-73$.

157. See Landes \& Posner, supra note 144, at 355.

158. That idyllic situation persists, of course, only untıl the onginal owner transfers certain denvatuve uses or other exclusive rights to others. But for Landes and Posner. the possibility of subsequent divided ownership is akin to Kitch's patent holder's efficient coordination of product deselopment It enables the original owner to license others who would be more efficient at exploiting particular uses than would the original owner herself. See id. at 355-56.

159. See Calabresi \& Melamed, supra note 123, at 1106-10

160. See id.

161. See, e.g., Krier \& Schwab, supra note 123, at 464 (mantauning that judicial refusal to internene by way of damages when market negotiations fail would encourage partses to leam hou to reduce transaction costs).

162. See POSNER, supra note 32, at 70 (stating that absent high transaction costs. strict liability trespass rule is preferred over nuisance rule because "[ $t$ ]he former, by refusing to consider the value of the invader's activity, channels the transaction into the market, where it belongs").

163. See Calabresi \& Melamed, supra note 123, at 1118-24; Gordon. Fatr Use, supra note 8. at 1609-10; see also POSNER, supra note 32, at 64 (noting congenital "nsk of ertor" whenever "count undertakes to determine market values"). 
Neoclassicists apply these same principles to copyright. They favor a proprietary copyright regime in which, absent incurable market failure, owners have the absolute right, backed by the ready availability of injunctive relief and punitive damages, to prevent unauthorized uses and to set licensing prices through ex ante negotiations. ${ }^{164}$ In corollary, they generally oppose compulsory licenses and would sharply restrict the availability of fair use. ${ }^{165}$ Neoclassicists argue further that a copyright owner should not have to show that it has been harmed in order to obtain injunctive or monetary relief for infringement. ${ }^{166}$

Significantly, neoclassicists favor this marketplace norm even where high transaction costs would block market transactions, so long as it appears that a property rule might lead to the development of institutions for overcoming such barriers. ${ }^{167}$ They maintain that strong property rules in copyright are a necessary predicate to the establishment of mechanisms, such as collective licensing and computerized tracking systems, that reduce transaction costs. ${ }^{168}$ In this view, then, even the presence of transaction costs leading to market failure is not sufficient to justify limitations on copyright owners' exclusive

164. See, e.g., Robert P. Merges, Of Property Rules, Coase, and Intellectual Property, 94 ColuM. L. REV. 2655 (1994) (arguing, generally, that proponents of liability rules in intellectual property carry heavy burden).

165. See, e.g., GOLDSTEIN, supra note 18, § 1.14.2.3(a), at 1:51-54 (suggesting that circumscribed compulsory licenses are appropriate only in face of insurmountable transaction cost barriers to market transactions); Merges, supra note 164, at 2668-73 (discussing cost of compulsory licenses). Similarly, Wendy Gordon asserts that compulsory licensing schemes are justifiable only when necessary to correct market distortions and that "the broad brush of this regulatory solution is too sweeping for most cases." Gordon, Fair Use, supra note 8, at 1613. The Copyright Act currently provides for various forms of compulsory licenses (including negotiated licenses subject to binding arbitration) in a number of areas, including certain secondary transmissions by cable systems, see 17 U.S.C. $\S 111$ (c) (1994), the public performance of sound recordings in certain digital audio transmissions, see id. $\$ 114$ (d)(2), cover recordings of nondramatic musical works, see id. $\S 115$, public performances of nondramatic musical works in jukeboxes, see id. $\S 116$, the use of published nondramatic musical works and published pictorial, graphic, and sculptural works in noncommercial broadcasting, see id. $\S 118$, and secondary transmissions by satellite carriers for private home viewing, see id. \$ 119. In addition, the fair use doctrine (codified at $i d . \S 107$ ), can be seen, in essence, as a compulsory license at a license fee of zero.

166. Gordon justifies copyright's strict liability nule with the argument that judges should not be involved in balancing interests, but rather should assume, in the ordinary copyright case, "that the defendant could have, and therefore should have, proceeded through the market." Gordon, Fair Use, supra note 8, at 1613; see also GOLDSTEIN, supra note $18, \S 1.14 .2(\mathrm{c})$, at 1:55 \& n.39 (maintaining that harm has no place in determining copyright infringement just as it is irrelevant to real property trespass).

167. See Paul Goldstein, Preempted State Doctrine, Involuntary Transfers and Compulsory Licensing: Testing the Limits of Copyright, 24 UCLA L. REV. 1107, 1118-34 (1977); Merges, supra note 164, at $2662-64$.

168. See, e.g., Landes \& Posner, supra note 144, at 358 (arguing that "fair use, if too broadly interpreted, might sap the incentive to develop market mechanisms that reduce transaction costs and make economic exchanges between copyright holders and users feasible"); Robert P. Merges, Contracting Into Liability Rules: Institutions Supporting Transactions in Intellectual Property Rights, 84 CAL. L. REV. (forthcoming Oct. 1996); Merges, supra note 164, at 2662-64. Merges has also argued that clearly defined property nules in copyright lessen negotiating costs by obviating the need of would-be licensees and licensors to recreate through contract their mutual rights and obligations, and determine the enforceability of their contract, each time they deal with one another. See Merges, supra note 22, at 1574. 
rights. ${ }^{169}$ Rather, copyright is to serve as an instrument for overcoming market failure. Only if market failure is seen to be endemic and insuperable might fair use or compulsory license be justified. ${ }^{170}$

\section{d. Transferability}

Although this attribute has little independent impact on the copyright expansion issues that are the focus of this Article, it bears mentioning that, for neoclassicists, property rights must be fully transferable so that they can be readily moved to the most highly valued uses. Accordingly, any restriction on entitlement alienability is generally viewed as an undesirable anomaly. ${ }^{173}$ Neoclassicists tend to view restrictions on the alienability of copyright with similar disfavor. For them, provisions that favor authors at the expense of subsequent transferees, such as provisions allowing authors to terminate copyright grants after a certain period or according authors so-called "moral rights" to prevent publishers and others from distorting their work, are an unwelcome barrier to free marketability. ${ }^{172}$

\section{The Marginality of Law}

Although it may appear at first glance to be contradictory, legal marginalism is a close adjunct to the neoclassicist belief in broad property rights and a broad copyright alike. In the Coasean universe of zero transaction costs, "the choice of legal rules... becomes a matter of supreme indifference." 173 Whatever entitlements or distributions the law creates are destined to be swept away in a whirlwind of bargaining as private parties engaged in an infinite array of frictionless transactions move resources to their highest valued use. ${ }^{174}$ Legal institutions are necessary in our fallen, positive

169. See GOLDSTEIN, supra note 2!, at 218 (maintaining that "the very dectston to extend copyngh into comers where transaction costs appear to be insuperably high may galvanize market forces necded to reduce transaction costs"); Gordon, Fair Use, supra note 8, at 1620-21 (argung that faur use should not general apply in situations of high transaction cost market failure when property rule might induce development of mechanisms for lessening transaction costs sufficiently to enable markets to function). Merges, supra note 164, at 2662.

170. See Gordon, Fair Use, supra note 8, at 1614-16, 1618-22, 1624-26 (discussing faur use)

171. For a cogent critique of this view, see RADIN, supra note 23.

172. For a discussion of restrictions on copyright alienability in United States and Conunental doctnne. see Neil Netanel, Alienability Restrictions and the Enhancement of Author Aufonomy in Unuted Stutes and Continental Copyright Law, 12 CARDOZO ARTS \& ENT. L.J. I (1994); Nell Netanel. Copynght Aluenubultry Restrictions and the Enhancement of Author Autonomy: A Normalne Evaluanon. 24 RLTGERS LJ 347 (1993) [hereinafter Netanel, Copyright Alienabiliry Restrictions].

173. Epstein, supra note 150, at 555. But see Roben C. Ellickson. A Crnique of Economic and Sociological Theories of Social Control, 16 J. LEGAL STUD. 67, 81-83 (1987) (crilicizung Coase and some law and economics scholars for giving insufficient attention to possibility of pnvate party. as opposed to state, delimitation of rights).

174. See BARZEL, supra note 127, at $55 \mathrm{n} .13$ (stating that under conditions of costless transactung. parties will clearly define property rights). 
transaction cost world, but for neoclassicists, even here they are subservient to the market. ${ }^{175}$ Their primary purpose is not to implement collective goals or social commitments. Law instead provides a mechanism for overcoming transaction cost barriers to ideal Coasean exchange and, where this is impractical, to stimulate or mimic the market by producing the perceived outcome of such exchange. ${ }^{176}$

The principle of legal marginalism colors the neoclassicist approach to copyright in four basic ways. First, to the extent that legal intervention is required to facilitate a market in original expression, legal marginalism is another reason why neoclassicists favor a property regime, rather than one that involves the state in subsequent allocation decisions. ${ }^{177}$ In addition to enabling copyright owners to set their own licensing price through ex ante negotiations, a property regime would avoid regulatory or judicial involvement in the valuation or allocation of rights to use expressive works. ${ }^{178}$ Once a broad, proprietary copyright has been created, such a regime would leave resource allocation to private ordering, rather than prospective government policy making or ex ante judicial fiat.

175. For a salient, in-depth analysis of how the drive to economize transaction costs has shaped legal and economic institutions, see WILLIAMSON, supra note 119. Williamson offers an internal critique of the neoclassical faith in pricing to bring about optimal resource allocation, arguing that far more attention necds to be paid to institutional dynamics, bounded rationality and other factors that hinder utility maximization.

176. See, e.g., POSNER, supra note 32, at 14-15 (arguing that where transaction costs prevent markets from securing efficient results, entitlements should be assigned to stimulate or mimic market by producing outcomes market would have produced); Epstein, supra note 150, at 555 (stating that "the central theme of all legal institutions [is] the effort to control transactions costs that impede voluntary exchange"). See generally GUIDO CALABRESI, THE COSTS OF ACCIDENTS 135-97 (1970) (analyzing determination of entitlements in accident law, given transaction costs).

For neoclassicists, the market not only provides the justification for law, it also shapes legal nules by directing judicial and legislative decisionmaking. According to neoclassicists, judge-made law, including common law and much of statutory interpretation, is the accumulated product of litigants' tendencies to challenge inefficient rules and judges' intuitive predisposition to find efficient solutions to legal disputes. See, e.g., POSNER, supra note 41, at 251-66; George L. Priest, The Common Law Process and the Selection of Efficient Rules, 6 J. Legal STUD. 65 (1977); Paul H. Rubin, Why is the Common Law Efficient?, $6 \mathrm{~J}$. LEGAL STUD. 51 (1977). For a biting critique of this position, see Bruce A. Ackerman, Law, Economics, and the Problem of Legal Culture, 1986 DUKE L.J. 929, 934-36. Legislation, neoclassicists claim, is the outcome of interest group bargaining and legislators' rational pursuit of their own self-interest. This is, of course, a central tenet of public choice theory. See generally DANIEL A. FARBER \& PHILIP P. FRICKEY, LAW AND PUBLIC CHOICE (1991). Lawmaking, in sum, is simply one more arena where market forces promote allocative efficiency. While market actors may choose to avail themselves of public institutions in certain instances, there is no normative reason why public institutions should be preferred over privatc contract for the definition and distribution of entitlements. In fact, given the costs involved in government regulation, it is often more efficient (and thus better) for private actors to arrange their affairs in the same manner as Coase's proverbial rancher and farmer, through market exchange.

177. See Merges, supra note 164 , at 2664-65 (favoring property over liability rule in intellectual property cases).

178. Gordon, for example, asserts that compulsory licensing schemes are justifiable only when necessary to correct market distortions and that "the broad brush of this regulatory solution is too sweeping for most cases." Gordon, Fair Use, supra note 8, at 1613. Similarly, she notes, regarding copyright's strict liability rule, that judges do not balance interests, but rather assume, in the ordinary copyright case, "that the defendant could have, and therefore should have, proceeded through the market." Id.; see also Goldstein, supra note 167, at 1128 (asserting that "[i]ike other systems of private property, copyright law is founded on the notion that privately bargained prices are preferable to publicly administered rates"). 
Second, legal marginalism supports the subordination of copyright to contract. ${ }^{179}$ It favors contractual arrangements, such as those that might be put into effect by online content providers, that systematically abrogate the limitations that copyright law imposes on owners' exclusive rights. ${ }^{\text {ISI }}$ For neoclassicists, such arrangements simply reflect the establishment of property rights through private ordering. ${ }^{181}$ As such, they are inherently more efficient than state efforts to define and delimit property rights since, by definition, the parties would not have agreed to such arrangements if they were inefficient.

Third, legal marginalism sharply limits the use of the copyright statute to achieve goals that neoclassicists describe as distributional. ${ }^{182}$ If one starts from the neoclassicist assumption that copyright owners are entitled to capture the economic value of existing works, then, absent insurmountable market failure, any copyright rule that enables selected groups or the public at large to use existing works without paying the full market price effects a distribution of wealth from owner to user. ${ }^{183}$ Seen this way, the support of public education and the free exchange of ideas through fair use news reporting, criticism, scholarship, and parody become an unwartanted extension of law into the realm of private ordering. ${ }^{184}$ Since broad property rights in original expression are deemed necessary to enable copyright owners to capture the economic value of existing works, a legal regime that establishes those rights comports with the neoclassicist preference for private ordering. But the use of

179. For an argument that a broad copyright-like prolection would have ansen esen without federa! intervention through a combination of contract and state ton lat protection aganst interference with prospective contractual relations, see Edmund W. Kitch. Commentan Intellectual Properth and the Common Law, 78 VA. L. REV. 293 (1992).

180. See supra text accompanying note 87; see also Roben L Dunne. Deterring L'numithorized Access to Computers: Controlling Behavior in Ciberspace Through a Coniruci Lm Paradigm. $35 \mathrm{~J}$ kivetrics J. 1 (1994) (favoring regime of privale contract for detemining scope and nature of content providet control); I. Tronter Hardy, The Proper Legal Regime for "C,berspace". 55 U PrT L REᄂ 993, 1029-31 (1994) (citing Coase for proposition that decentralized contract should generally be favored over entralized statute to address various cyberspace problems, including those colermınous with cop) nght). Merges. stupra note 168 (lauding examples of quasi-copyright through contract)

181. See, e.g., ProCD. Inc. v. Zeidenberg. 86 F.3d 1447. 1455 (7th Cir 1996) (tendenng opinion. authored by noted neoclassicist. Judge Frank Easterbrook, upholding enforceability of shnnk urap licenses as "private ordering" that is "essential to the efficient functioning of maskets")

182. See, e.g.. NII WHITE PAPER, supra note 6, at 84 (asserting that copy nght ouners" nghts should not be limited to redress inequalities between information haves and have-nots). Gordon. Fair Uste. stupra note 8, at 1615, 1632 (maintaining that fair use doctrine should nether be used for purpose of "deprining copyright owners of their . . propeny precisely when they encounter those users who could afford to pay for it," nor to "tax copyright owners to subsidize impecuntous but mentonous users")

183. See, e.g., GoLDSTEIN, supra note 21, at 224-25 (referning to statulong exemptuons to copynght liability for uses such as classroom performances of copynghted worhs in nonprofit educational institutions as "distributional aspects of [Congress's] copynght agenda"): Gordon, supra nole 105, at 14t9 (arguing that, except in isolated instances of "extremely strong public need," copynght holder"s entitlement to prohibit nonconsensual uses is correet baseline for evaluaung distnbutional effects of copy nghi doctrne) But see Merges, supra note 164, at 2661 (describing tendency of intellectual propeny lau to favor creators rather than infringers as "built-in distributional bıas").

184. Cf. Goldstein, supra note 167, at 1136-37 (contending that “[b]ecsuse copynght is founded on the primacy of private decisions, any proposal to introduce compulsony licensing bears the heavy burden of showing that the benefits to be derived from compulsory licensing ourweigh the cosis") 
law to support transformative and educative uses of existing works causes market distortions and is akin to state-sponsored theft. Hence Posner argues that, whatever the benefits of social, political, and aesthetic criticism to our system of free expression, fair use should never be available for satiric uses of existing works because such uses present no problem of congenital market failure: "But, as we do not suppose that writers should be allowed to steal paper and pencils in order to reduce the cost of satire, neither is there a compelling reason to subsidize social criticism by allowing writers to use copyrighted materials without compensating the copyright holder."

Finally and most generally, legal marginalism reinforces the principle that the purpose of copyright, like that of all law, is simply to facilitate an efficient allocation of resources through private ordering. As such it undermines, if not radically opposes, the traditional idea that copyright serves to further the public interest in expressive diversity and public education. Neoclassicists may well believe that an untrammeled market in broad, proprietary rights to use authors' works will in fact promote public education and expressive diversity, perhaps even at a more optimal level than would a copyright statute designed to balance incentive and access. ${ }^{186}$ But even if such a belief were wellfounded-and I shall argue that it is not-this would ultimately be no more than a fortunate byproduct of a regime that treats expression like any other vendible commodity. If nothing else, the notion that the social value of expression may be measured in terms of market price encourages the subversion of copyright's constitutive goals and its conversion into a general misappropriation statute. ${ }^{187}$

\section{The Neoclassical Market Paradigm Versus Copyright's Democracy- Enhancing Goals}

To their credit, leading intellectual property scholars who have advanced the neoclassicist approach generally seek to place the market paradigm within

185. Richard A. Posner, When is Parody Fair Use?, 21 J. LEGAL STud. 67, 73 (1992). In contrast, according to Posner, parodic uses, which target the parodied work itself, may be subject to market failure since "it may be in the private interest of the copyright owner, but not in the social interest, to suppress criticism of the [copyright owner's] work." Id. Posner also argues that according fair use treatment to certain uses might promote an "excessive allocation of resources" to those uses and a resultant underutilization of works that are not subject to fair use, "as potential buyers of this intellectual property switch to its free competitor." Id. at 72.

186. Posner has argued, for example, that a reading of the fair use doctrine that effectively puts some forms of intellectual property into the public domain, "where [they] can be used without being paid for, may cause the priced forms to be even more underutilized from a social standpoint." Id;; see also GOLDSTEIN, supra note 21, at 236 (maintaining that extending copyright "into every corner where consumers derive value from literary and artistic works" would promote "political as well as cultural diversity").

187. Cf. RADIN, supra note 23, at 166-72 (describing manner in which conceptualization of expression as market rhetoric context may undermine our cultural commitments to active citizenship. collective sclfgovernment, and individual human flourishing). 
a framework that affirms copyright's fundamental democracy-enhancing goals. They recognize that copyright serves to promote important public interests, including the First Amendment values of robust debate, citizen education, and expressive diversity, that are not reflected in many consensual licensing transactions. Neoclassicists address this inconsistency between public interest and an untrammeled market in a number of different ways. At times they attempt to incorporate public interests within the market paradigm by defining as a "transaction cost" the parties' congenital failure to account for them. In other instances, they fall back on the dichotomy between unprotected idea and protectible expression, contending that even if copyright assumes proprietary proportions, the dichotomy continues to set a tenable limit on private censorship. ${ }^{189}$ In still other instances, neoclassicists simply concede that the market paradigm perhaps should not apply in certain discrete cases involving paramount nonmonetizable interests. ${ }^{100}$ Finally, neoclassicists sometimes assert that even if a broad proprietary copyright might appear in some cases to trammel expressive diversity, it ultimately promotes diversity by enabling publishers better to tailor their investments to meet consumer choice. ${ }^{191}$

In this Section, I will contend that such efforts to account for First Amendment values and other democracy-enhancing goals within or alongside the neoclassicist approach are only minimally successful at best. I will first consider two examples, an essay by Robert Merges on parody. ${ }^{192}$ and Wendy Gordon's seminal article on fair use. ${ }^{193}$ I will maintain in each case that the neoclassical market paradigm leads the writer to favor an exceedingly broad scope of copyright protection, despite the writer's purported attempt to place limits on the paradigm's effect. I will then critically examine Paul Goldstein's argument that a broad copyright is compatible with democratic values because extending "rights into every corner where consumers derive value" will promote expressive diversity. ${ }^{194}$

Professor Merges's essay applies what he terms the '.market-centered' view of copyright" to the parody fair use defense, focusing on the case of Acuff-Rose Music, Inc. v. Campbell. ${ }^{195}$ In Campbell, the popular music group "2 Live Crew" had released a rap version of Roy Orbison's soft rock ballad

188. See, e.g., Merges, supra note 105, at 309-10.

189. See infra note 252 .

190. See, e.g., Gordon, Fair Use, supra note 8, at 1632 (descnbing "not illegitumale" judictal coneen that in some cases "criterion of economic "value" is itself flawed")

191. See. e.g., GoLDSTEIN, supra note 21. at 236.

192. See Merges, supra note 105.

193. See Gordon. Fair Use, supro note 8.

194. GOLDSTEIN, supra note 21, at 236. None of these eminent commentators. 1 wish to emphasize again, has adhered consistently to a neoclassicist approach. Stnkingly, however, to the exient that they have followed that approach, the expansionist neoclassicist model has appeared to tnump whatever concerns they have elsewhere expressed about treating copyright as a broad property nght.

195. 972 F.2d 1429 (6th Cir. 1992). 
"Oh, Pretty Woman." Orbison's music publisher, Acuff-Rose, sued the group for copyright infringement, and the defendants asserted that their version of the song constituted a parody of the Orbison original, which, the defendants contended in line with longstanding precedent, counted strongly in favor of a finding of fair use under the Copyright Act. The Sixth Circuit reversed the district court's finding of fair use, questioning whether 2 Live Crew's version was really a parody of the Orbison song as opposed to a more general social satire and holding that the commercial nature of the rap group's copying raised a presumption against fair use that the defendants had failed to overcome. ${ }^{196}$

When Professor Merges wrote his essay, the Supreme Court had just granted certiorari to hear the case. ${ }^{197}$ Subsequently, in a potentially farreaching decision, the Court reversed the Sixth Circuit and remanded the matter for further findings. ${ }^{198}$ The Court emphasized that because all authors necessarily borrow from the work of their predecessors, fair use for transformative uses is an integral part of copyright, serving the same constitutive purpose of promoting individual creativity and public education as does the grant of exclusive rights to authors and their assigns. ${ }^{199}$ The Court then rejected the notion that the commercial nature of the petitioner's use creates a presumption against fair use, holding that "the more transformative the new work, the less will be the significance of other factors, like commercialism, that may weigh against a finding of fair use." ${ }^{200}$ It also rejected the Sixth Circuit's rigid distinction between parody and broader social commentary, holding that a work will be treated as a parody so long as its parodic character may "reasonably be perceived,"201 and that, in any event, fair use may be readily applicable to nonparodic transformative uses, no less than to parodies, whenever "there is little or no risk of market substitution."202 Finally, the Court suggested that given copyright's paramount goal of stimulating "'the creation and publication of edifying matter," 203 in cases of colorable but failed claims of fair use for transformative secondary works, courts should award damages rather than grant

196. See id. The Sixth Circuit grudgingly assumed for purposes of its argument that the 2 Live Crew version was parodic in character, see id. at 1435, but its doubts on that score seem to have affected its analysis nonetheless.

197. See Campbell v. Acuff-Rose Music, Inc., 113 S. Ct. 1642 (1993) (granting certiorari).

198. See Campbell v. Acuff-Rose Music, Inc., 114 S. Ct. 1164 (1994). The Court remanded the case for a determination of whether 2 Live Crew's repeated use of the original song's opening bass riff was excessive for the group's parodic purpose and whether the rap parody would usurp the market for nonparody rap versions of the original. See id. at 1176-77, 1179.

199. See id. at 1171. Stating that copyright's goal of promoting science and the arts is "generally furthered by the creation of transformative works," the Court emphasized that such works "lie at the heart of the fair use doctrine's guarantee of breathing space within the confines of copyright." Id. At the same time, the Court rejected the petitioner's suggestion that parodies should be presumptively fair use. See id. at $1172-73$.

200. Id. at 1171 .

201. Id. at 1173 .

202. Id. at 1172 n. 14 .

203. Id. (quoting Leval, supra note 19, at 1134). 
injunctive relief, in effect issuing a compulsory license to further the "'strong public interest in the publication of the secondary work." 20 . In sum, the Court affirmed in Campbell that uses incorporating significant defendant contributions may well qualify for fair use or judicial compulsory license even if the defendant could have paid the ex ante market price for the use..$^{\text {.05 }}$

Professor Merges purports to set forth a market-based, value-neutral analysis of fair use that would make considerable room for parodic works. ${ }^{200}$ His essay not only criticizes the Sixth Circuit's ruling, but also contends that a fair use defense might be available to 2 Live Crew "only if one takes the economic view of copyright quite seriously."207 At closer examination, however, Merges's neoclassicist approach leads him to a position that is quite at odds with the conclusions he purports to draw. His adherence to the market paradigm supports an exceedingly limited parodic fair use exception to the copyright holder's proprietary right, and one that is far more circumscribed than that which the Supreme Court later enunciated in Campbell.

Professor Merges begins his analysis of parody fair use with the basic proposition that copyright is based on a norm of "consensual market transfers" 208 and that "[d] eviations from this norm must be pleaded with special facts, and convincingly." 209 He allow's that "social welfare considerations have a place in intellectual property law."210 But he defines social welfare in market terms, maintaining that social welfare is best furthered by market transactions and that legal intervention is justified only when the private parties' failure to contract arises from the absence of a viable market in a particular context. ${ }^{211}$ Merges then suggests that parody may often represent an instance of such market failure since the copyright owner of the parodied work may refuse to grant a license for the parody because of a "noneconomic" motive, the desire to squelch the parody rather than an absence of agreement on a licensing price. ${ }^{212}$ For Merges, such insurmountable market failure, resulting in this case from the congenitally high "transaction costs" of overcoming the owner's "noneconomic" resistance to granting a license, may justify the "coerced exchanges" inherent in findings of fair use. $^{213}$

Merges, however, is not content to follow the traditional presumption, subsequently reaffirmed by the Supreme Court in Campbell, that copyright

204. Id. at 1171 n.10 (quoting Leval. supra note 19. 3 1132)

205. See id. at 1171 n.10, 1172 n.14. 1177-78.

206. See Merges, supra note 105 , at 312 .

207. Id. at 307 .

208. Id. at 306 .

209. Id. at 307

210. Id.

211. See id.

212. See id.

213. See id. at 309-10. 
owners will generally refuse to license parodies of their works. ${ }^{214} \mathrm{He}$ insists that the parodist must prove a clear failure in the market in each case. ${ }^{215}$ The parodist could establish either "(1) that a consensus of licensing experts agrees that the parody will not appreciably injure the market for the original work; or (2) that, prior to the release of the parody, the parodist made an offer to pay a royalty that would generously compensate the copyright holder." ${ }^{\text {216 }}$ With regard to the first possibility, Merges neither defines "appreciable injury" nor states whether the relevant market includes the market for licensing parodies. Given Merges's assumption that a parody licensing market is possible, it would appear that any unlicensed parody would cause some appreciable injury to that market. In any event, Merges's focus is on the second alternative, the requirement that the parodist actually offer to compensate generously the copyright holder. That requirement, he asserts, would determine whether or not the copyright holder's refusal to deal was based on economically rational motives.

The generous compensation alternative contains a number of crucial concepts that Merges fails to clarify. Aside from the obvious indefiniteness of the term "generously," he does not set forth what is to be the basis for compensating the copyright holder, that is, whether the copyright holder is entitled to be paid for any degree or type of injury to any possible market or just for some injuries to some markets. This ambiguity is exacerbated by his failure to distinguish convincingly between impermissible noneconomic motives and permissible economic ones. On the one hand, Merges states that the holder's refusal to license a parody that the holder simply finds distasteful is not economically rational and thus would support judicial intervention. ${ }^{217}$ On the other hand, he suggests that, even if the prospective parodist is willing to pay the standard license fee, the holder's desire to prevent a parody from harming the holder's reputation may be a legitimate economic concern and that the techniques used in defamation cases for valuing such harm can similarly be employed in calculating the compensation that a prospective licensee must offer the holder. ${ }^{218}$

214. See Campbell v. Acuff-Rose Music, Inc., 114 S. Ct. 1164, 1178 (1994); see also Fisher v. Decs, 794 F.2d 432, 437 (9th Cir. 1986) ("The parody defense to copyright infringement exists precisely to make possible a use that generally cannot be bought.").

215. See Merges, supra note 105, at 307. Paul Goldstein also suggests that this should be the case. While granting that copyright owners will generally refuse to license parodists, he insists that the parodic nature of the defendant's use should not necessarily count in favor of fair use, in part because "the copyright owner may be sufficiently thick-skinned to be willing to license defendant's use for a fec or, indeed, to enter the market for the "parody' himself." GoLDSTEIN, supra note 18, $\$ 10.2 .1$, at 10:24.

216. Merges, supra note 105, at 307 (emphasis added).

217. See id. at 308-10. As Merges concedes in a footnote, many economists would argue that any subjective preference regarding the relative private utility of alternative possibilities is an "economic" valuc. See id. at 310 n.24.

218. See id. at 310 n.26. 
Significantly, Merges fails to discuss what most courts and commentators assume is the most common reason that copyright holders refuse to license parodies. As seems to have been the case in Campbell, the holder's refusal generally stems from a real and understandable concern that a biting lampoon will suppress or even destroy demand for the holder's work. ${ }^{219}$ Given this concern, a holder's refusal to license for any price less than what would compensate it for such loss reflects perfect economic rationality -and Merges's generous compensation standard would have to reflect that calculation. Nevertheless, as the Supreme Court reaffirmed in Campbell, the commercially harmful effects of criticism cannot be taken into account in determining fair use, no matter how severe their impact or how economically rational the holder's desire to avoid them. ${ }^{220}$ The reason is that the nonmonetary social benefit of such criticism outweighs any constraint on the holder's market prerogatives, except potentially when the secondary work acts as a market substitute for the original or its derivatives. ${ }^{221}$

Towards the end of his essay, Merges notes that his transactional account of the parody defense is very different from a "First Amendment view," in which "the parody is either privileged free expression or it is not" and "[t]he ability or willingness of the parodist to pay is irrelevant." $22 \mathrm{He}$ then concedes momentarily that perhaps his theory shortchanges First Amendment values. ${ }^{223}$ But in closing, Merges returns to what appears to be the root of much of the allure of the neoclassicist approach, its seeming value-neutral precision in contrast to the policy-laden openness of balancing private and public interests. He contends that by looking at the existence of and reasons for a real bargaining breakdown, rather than the nature of the defendant's transformative use, courts will attain a more manageable "market neutrality.,224

As is evident, however, from Merges's vague standards for determining whether a cognizable bargaining breakdown has occurred, the neoclassicist approach is itself far from determinate. ${ }^{225}$ At the same time, his neoclassicist insistence that "consensual transfers are so much the norm in copyright law that coerced exchanges must be convincingly justified" inevitably tilts the scale in the direction of broad, absolutist protection, upending copyright's traditional,

219. See Campbell, 114 S. Ct. at 1178.

220. See id.; see also 3 NIMMER ON COPYRIGHT, supra note S6, $\$$ 13.05[A], at 13-187 to I3-188 ("“[A] cour need not take into account an adverse impact on the polential market for planuff's work by reason of a disparaging or otherwise unfavorable reference in defendant's work to plantiff's work.").

221. See Campbell, $114 \mathrm{~S}$. Ct. at 1178 (distinguishing between "potentially remediable displacement" and "unremediable disparagement").

222. Merges, supra note 105 , at 312 .

223. See id.

224. See id.

225. For a critique of the indeterminacies and inaccuracies in neoclassical economic theory generally. see supra note 113 and infro text accompanying notes $241-48$. 
delicate balance between robust incentive and public access. ${ }^{226}$ Perhaps most tellingly, Merges concedes in a footnote that the facts as presented in Campbell would not meet his standard for fair use because 2 Live Crew offered to pay Acuff-Rose merely the statutory compulsory license fee for a "cover" recording and not the full (i.e., generous) market price. 227

In her early and influential article on fair use, Professor Gordon similarly sought to employ a "market approach" at least in part to counter judicial restriction of fair use, in this instance the Ninth Circuit's holding that fair use is unavailable for nontransformative uses. ${ }^{228}$ But like Professor Merges, Professor Gordon's adherence to neoclassicist economics in that article leads her to treat fair use as an anomalous deviation from copyright's marketplace norm, available only in occasional cases of incurable market failure. ${ }^{229}$ Gordon purports to emphasize that certain uses may yield "external" social benefits that will not be reflected in the price the prospective user would be willing to pay or may significantly further "nonmonetizable values," such as "public knowledge, political debate, or human health."230 But given her neoclassicist orientation, she carefully cabins these cases, asserting that fair use should apply "[o]nly when the public interest to be served is great, and the damage to the owner small."23i To that end, Gordon would impose on the defendant the burden of proving insurmountable market failure and demonstrating that his use serves an identifiable public interest that would outweigh any harm caused to the copyright holder by granting fair use. ${ }^{232}$ In

226. Merges, supra note 105 , at 310 .

227. See id. at 310 n.26.

228. In the so-called "Betamax" case, the Ninth Circuit held that home videotaping of television programs did not constitute a fair use. See Universal City Studios, Inc. v. Sony Corp., 659 F.2d 963 (9th Cir. 1981). The Supreme Court subsequently reversed, holding that noncommercial home videotaping for the purpose of viewing a program at a later time, as opposed to keeping a copy for repeated viewing, posed no market harm to plaintiffs and thus constitutes a fair use. See Sony Corp. v. Universal City Studios, Inc., 464 U.S. 417 (1984). Professor Gordon's article was cited in Justice Blackmun's dissent in Sony, see id. at 478 (Blackmun, J., dissenting), and, the following year, in the majority opinion in Harper \& Row, Publishers, Inc. v. Nation Enters., 471 U.S. 539, 559, 566 n.9 (1985). The Sony dissent and Harper \& Row majority each supported a highly restrictive interpretation of the applicability and scope of fair use.

229. Professor Gordon's article on fair use was her first published foray into the field of intellectual property. Since then she has come to place far greater emphasis on nonmonetary values relating to the creation and use of creative expression and has come unequivocally to oppose the idea that all social value should be propertized. See, e.g., Gordon, Self-Expression, supra note 8.

230. Gordon, Fair Use, supra note 8, at 1631.

231. Id. at 1632 .

232. See id. at 1624-25. When Gordon wrote her article, the question of how the burden of proof was to be allocated in fair use litigation was a matter of substantial disagreement among courts and commentators. See id. at $1624 \mathrm{n} .135$. The rule that has emerged since then, while still uncertain, appears to be that the burden of proof is generally on the party asserting fair use, except when the use is of a lype that generally counts in favor of fair use, including noncommercial and educational uses. Compare Campbell v. Acuff-Rose Music, Inc., 114 S. Ct. 1164, 1177 (1994) (citing Harper \& Row. 471 U.S. at 561) (holding, in case involving commercial parody, that fair use is affirmative defense, elements of which must thus be proven by defendant), with Sony Corp., 464 U.S. at 45 ! (holding that burden of proving market harm falls on defendant when commercial use and on plaintiff when noncommercial). See also Princeton Univ. Press v. Michigan Document Serv., Inc., 74 F.3d 1512 (6th Cir.), vacated pending reh'g en banc, 74 F.3d 1528 (6th Cir. 1996) (distinguishing Campbell from Sony on basis of nature of defendant's use and 
addition, in order to correct for possible errors in judicial valuation and to make certain that "the market can be safely bypassed," Gordon would deny fair use, even when market failure and importan social benefit have been demonstrated, whenever it would "leave the plaintiff copyright owner facing substantial injury to his incentives." ${ }^{.233}$ Therefore, despite her expression of concern for nonmonetizable social benefits, Professor Gordon's adherence to neoclassicist precepts leads her to a sharply circumscribed view of fair use.

In his recent account of copyright's digital future, ${ }^{23}$ Professor Goldstein expresses even greater reluctance than Professors Merges and Gordon to countenance exceptions to the neoclassical marketplace norm. He asserts that fair use should be invoked only in cases of bilateral market failure, which, he contends, in the coming age of nearly costless collective and digital licensing, would rarely, if ever, occur. ${ }^{235} \mathrm{He}$ would limit copyright's breathing space for socially valuable ends to narrow statutory exemptions for specifically identified uses (like classroom performances in nonprofit educational institutions) or, possibly, cash subsidies that specified users could apply towards paying the full market price for a license. ${ }^{236}$ At the same time-and this appears to be central to his strident adherence to the market paradigm-Professor Goldstein contends that the neoclassicist approach is fully compatible with copyright's democracy-enhancing objectives. He gives special emphasis to the neoclassicist faith in the capacity of the pricing system to signal consumer preferences, and he equates consumer purchasing decisions with expressive diversity. ${ }^{237}$ Professor Goldstein asserts that copyright serves essentially as a mechanism for authors and publishers to identify and meet consumer preferences, and that the more consumer uses are included within the ambit of copyright holders' exclusive rights, the more holders will tailor their investment in the creation and development of creative works to reflect the full array of consumer market segments. ${ }^{238}$ Professor Goldstein thus maintains that "to extend rights into every corner where consumers derive value from literary and artistic works," a broad proprietary copyright would in fact "promote political as well as cultural diversity."

imposing on plaintiffs burden of proving meaningful likelihood of future harm to potential market for copyrighted works)

233. Gordon, Fair Use, supra note 8. at 1619.

234. See GolDSTEIN, supra note 21, at 197-236.

235. See id. at 224.

236. See id. at 224-25.

237. Professor Goldstein is not alone among neoclassicist copyright scholars in toutung pnce signaling as a supposed benefit of copyright. See supra notes 8. 228-33 (discussing Professor Gordon's position)

238. See GOLDSTEIN, supra note 21, at 35, 179. 228-29. Professor Goldstern views a copynght holder's ability to engage in price discrimination among vanous consumer groups as an integral part of copyright's consumer signaling system. See id. at 8 . Along these lines. he looks favorably on the possible development of licensing technologies that will enable copynght holders to engage in ever more precise price discrimination. See id. at 224.

239. Id. at 236. Although he does not expressly say so, it would appear that Professor Goldstein intends to apply this reasoning to transformative, as well as consumptuve, uses given his vew that the 
I am in substantial agreement with Professor Goldstein, particularly vis-àvis some of the sharpest critics of copyright expansion, that at least a relatively strong copyright is a prerequisite of expressive diversity. But the democratic paradigm that I advance diverges from Professor Goldstein's approach in two important respects. First, it supports a relatively strong copyright only as a blunt instrument for insuring a vital, independent sector for the creation and dissemination of original expression. The democratic paradigm eschews the neoclassicist pricing model and questions whether market pricing can serve with any reasonable degree of precision as a mechanism for producer direction of investment toward diverse audiences. ${ }^{240}$ Second, the paradigm places a greater emphasis on the costs of an overly broad copyright monopoly.

Although a full discussion of the inadequacies of the pricing model, both generally and with respect to copyright, is beyond the scope of this Article, I will briefly mention a few problems. To begin with, the substantial literature on the bounded rationality of both consumers and producers belies any mechanical application of the neoclassicist pricing equation. On the consumer side, studies show that consumer tastes and purchasing decisions are highly malleable and heavily influenced by taste addiction, status quo biases, herd

exclusive right to make derivative works serves, like the remaining panoply of copyright owner prerogatives, to direct owner investment in accordance with consumer preferences. See GOLDSTEIN, supra note $18, \S 5.3$, at 5:79. Elsewhere, he has insisted that copyright law "must not impose too severe a prohibition against authors' borrowing from others." Goldstein, supra note 22, at 80 . But his willingness to curtail copyright owner control over transformative uses to accomplish this purpose seems limitco, at best, to (1) cases of intractable market failure (including some, but not all, parodies), see GoLDSTEIN, supra note $18, \S 10.2 .1 .2$, at 10:23; (2) his (to my mind, meager) suggestion that infringing derivative works should themselves be entitled to copyright protection, see supra note 155; and (3) the traditional, but illdefined, notion that whatever constraints copyright may impose on transformative uses of "expression," "ideas" should be free for all to use, see infra note 252. Professor Goldstein has also questioned whether infringing derivative works that require a large-scale investment of time and money (such as motion pictures, television series, and advertising campaigns) and derive only to a minor extent from an underlying work, should be subject to injunctive relief. See Goldstein, supra note 70, at 238. He cautions, however, that, "like compulsory licenses generally," withholding injunctive relief "may improperly reduce investment incentives by proportioning the copyright proprietor's returns to terms that an official tribunal belicves are just rather than to terms privately struck in the marketplace." Id. at 239 n.94.

240. The paradigm also lends far greater emphasis than does Professor Goldstein's market model to an important aspect of expressive diversity in a democratic society: that of the reformulation of prevailing cultural icons in order to challenge mainstream values and assumptions. See infra text accompanying notes 361-62. This subversive reformulation aspect of expressive diversity demands limits on copyright owner control over transformative uses. Professor Goldstein's primary focus, in contrast, seems to be on expressive diversity in the sense of product differentiation. See Goldstein, supra note 167, at 1135 (opposing compulsory licenses in part because they would impose artificial ceiling on market revenues and thus "will reduce the range of differentiation among works produced"). According to his market model, that aspect of diversity would be best served by broad, proprietary rights, so that copyright proprietors would have incentives to meet varied consumer demand. See id. at 1135, 1140. It might also be argued that broad proprietary rights would encourage subsequent authors to come up with novel, nonderivative expressive works. Cf. id. at 1135-36 (noting that copyright law might encourage greater product differentiation if it required higher threshold of originality as condition of protection and proscribed subsequent author borrowing of ideas as well as expression). The equation of expressive diversity with product differentiation overlooks the extent to which highly derivative transformative uses, such as parody, may be valuable or necessary to challenging the ideas and sensitivities embodied in preexisting expression. 
behavior, and other preference shaping distortions. ${ }^{2+1}$ As a result, consumer purchases do not reflect the full array of potential audience receptivity. On the producer side, especially given the dynamics of bureaucratic organization, managers are unlikely to respond to consumer pricing signals in accordance with the neoclassical model of economic rationality. ${ }^{242}$ In particular, according to several theoretic models, book publishers, film studios, and other media organizations show an inherent bias against minority tastes and in favor of expression that is likely to appeal to large audiences. ${ }^{233}$ This is especially the case in those sectors characterized by firm concentration, which, given the unabated growth of multimedia conglomerates in recent years, are now absorbing a greater and greater share of the copyright marketplace. ${ }^{2+1}$

Moreover, there is little evidence to support the traditional neoclassical notion, which is also a linchpin of the pricing model, that an unhindered market inexorably leads to the evolution of efficient institutions. As Mark Roe has recently asserted, economic institutions are shaped largely by arbitrary conditions, local evolution, and path dependence, not simply or even predominantly by producer capacity to respond to consumer demand. 2ss To

241. See, e.g., Daniel Kahneman et al., Anomalies: The Endowment Effect. Loss Averstont, and Siutus Quo Bias, J. ECON. PERSP., Winter 199!, at 193 (presentıng evidence supporting endowment effects and status quo biases and discussing their relation to loss aversion); George Loewenstean \& Samuel lssacharoff. Source Dependence in the Valuation of Objects, 7 J. BEHAV. DeCision Miskisg 157 (1994) (finding that means by which people obtain objects impacts their valuation of them): James $G$ March. Bounded Rationality, Ambiguity, and the Engineering of Choice, in RATIONAL CHOICE 142 (Jon Elster cd. 1986) (discussing studies on role of taste in rational choice); Robert J. Shtller, Conversation. Informunton, and Herd Behavior, 85 AM. ECON. REV. PAPERS \& PROC. 181. 181 (1995) (discussing systematic ".herd externality, of imitating others and thereby concealing one's own information"). Cass R Sunstein. Legal Interference with Private Preferences, 53 U. CHI. L. REV. 1129. 1145-66 (1986) (canvassing consumer preference scholarship); David Throsby. The Praduction and Consumption of the Arts A View of Cultural Economics, 32 J. ECON. LTT. 1, 3 (1994) (discussing role of acquired taste and taste addiction in individuals' consumption of ars).

242. See, e.g., Williamson, supra nole 119. al 45; see also Herbert A Simon. Rutiontan in Psychology and Economics, in RATIONAL CHOICE: THE CONTRAST BETWEEV ECOvONICS AND PSYCHOLOGY 25, 33-40 (Robin M. Hogarth \& Melvin W. Reder eds. 1987) (suneying evidence that neoclassical economic theories of substantive rationalıty and utılsty maximization fasl to explan fims' decisions).

243. See BRUCE M. OWEN \& STEVEN S. WILDMAN. Video ECONOMics 101-50 (1992) (surveying their own models and those of others).

244. See Diana Crane. The Production of Culture: Media and the Urba arts 55-75 (1992) (canvassing studies that link production of mainstream, prosatc expression with increased concentration of media ownership); Paul DiMaggio, Marker Stricture, the Creatuve Process, and Popular Culiure Tovard an Organizational Reinterpretation of Mass-Culture Theon: 11 J. POPULAR CLLTLRE 436.40 (1977) (noting that larger, established media organizations have poorer record than do smaller, independent hirms in providing innovative products). For a general. and somewhat polemic. discussion of concentration in the media, see BEN BAGDIKIAN, THE MEDIA MONOPOLY 3-26 (1992). For a chart showing significant entertainment company interrelationships as of 1990 in the areas of film. broadcasting and cable. sec HAROLD L. VOGEL, ENTERTAINMENT INDUSTRY ECONOMICS: A GUIDE FOR FINANCIAL ANALYSIS SS (1990). For discussions of the concentration of ownershtp among book publishers in the hands of multimedia conglomerates, see Michael J. Robinson \& Ray Olszewski. Books in the Marketpluce of Ideas. 30 J. COMM. 81, 84-85 (1980); Jason Epstein. The Decline and Rise of Publishing. $N Y$ REV Books. Mar 1,1990 , at $8,9-11$.

245. See Mark J. Roe, Choos and Evolution in Law and Economscs. 109 HARV L REV 6+1 (1996) For an insightful and more detailed discussion of path dependence in the development of institutions. see 
take a pertinent example, the film industry is notorious for its relentless overinvestment in big event and big star pictures, driven far more by its peculiar corporate culture and capital structure than by any economically rational response to market pricing signals. ${ }^{246}$

Finally, in addition to these consumer and producer rationality distortions, recent game theoretic studies of strategic bargaining seek to demonstrate that limited entitlement regimes, including liability rule and divided ownership systems, may, in some circumstances, actually provide greater inducements for efficient consensual transfers than full, neoclassical property rules. ${ }^{247}$ To the extent that these studies are applicable to copyright-and it appears that they would apply to many transactions, particularly those concerning transformative uses of existing works-they suggest that an expansive proprietary copyright might not be the best vehicle for channeling producer investment to meet audience tastes, even assuming that market pricing affords a fairly accurate indication of those tastes. ${ }^{248}$ In short, while the copyright system as a whole

NORTH, supra note 119, at 95-104.

246. For a detailed discussion of this phenomenon, see JOHN IZOD, HOLLYwOOD AND THE BOX OFFICE 1895-1986, at 141-87 (1988). Cf. John Pick, The Compulsion Towards Inefficiency, in ECONOMICS OF Cultural DECISIONS 110 (William S. Hendon \& James L. Shanahan eds., 1983) (maintaining that cultural and artistic expectations, ritualized techniques, group mythologies, and embedded commercial practices have driven London West End theaters regularly to put on lavish, unprofitable productions).

247. See Ian Ayres \& Eric Talley, Solomonic Bargaining: Dividing a Legal Entitlement To Facilitate Coasean Trade, 104 YALE L.J. 1027 (1995) [hereinafter Ayres \& Talley, Solomonic Bargaining]. Ayres and Talley maintain, in essence, that when two parties have private information about how much they valuc an entitlement, giving each party a partial claim to the entitlement (either by imposing a liability rule or by dividing ownership) in a manner that creates ambiguity or uncertainty about who is the buyer and who is the seller can reduce the parties' incentive to withhold valuation information during bargaining, thus facilitating efficient trade. See id. at 1029-30. Louis Kaplow and Steven Shavell have challenged this thesis in part, arguing that although bargaining occurs under liability rules when transaction costs are low, liability rules are not especially conducive to bargaining (although they may induce efficient nonconsensual takings and need not be less conducive to bargaining than are property rules). See Louis Kaplow \& Steven Shavell, Do Liability Rules Facilitate Bargaining? A Reply to Ayres and Talley, 105 YALE L.J. 221, 224-32 (1995) [hereinafter Kaplow \& Shavell, Reply]; Louis Kaplow \& Steven Shavell, Property Rules Versus Liability Rules, 109 HaRv. L. Rev. 713 (1996) [hereinafter Kaplow \& Shavell, Property Rules]. Kaplow and Shavell do, however, agree with Ayres and Talley that divided ownership may better facilitate efficient trade than would full, neoclassical property rights. See Kaplow \& Shavell, Reply, supra, at 222 n.5; see also Ian Ayrcs \& Eric Talley, Distinguishing Between Consensual and Nonconsensual Advantages of Liability Rules, 105 YALE L.J. 235 (1995) (responding to Kaplow \& Shavell critique); Jason S. Johnston, Bargaining Under Rules Versus Standards, 11 J.L. ECON. \& ORG. 256 (1995) (maintaining that bargaining under standards may be more efficient than bargaining under rules).

248. See Ayres \& Talley, Solomonic Bargaining, supra note 247 , at $1039-42$ \& n.48 (labelling copyright compulsory licenses for musical recordings, songs played on jukeboxes, certain cable television transmissions, and certain uses of copyrighted works by public television as classic untailored liability rules that favor information disclosure, thus encouraging consensual transfers). Robert Merges argues that Ayres's and Talley's model is applicable only in cases of bilateral monopoly and not, as in the case of copyright, where an entitlement holder would have to buy out multiple potential takers, some of whom might even threaten infringement entirely to extort a payment. See Merges, supra note 168, manuscript at 18. For a further discussion of this multiple taker problem, see infra notes 425-26 and accompanying text. Merges is only partly correct, and even here he misses the point. The multiple taker problem would arise only where the liability rule takes the form of a compulsory license in which a license fee is specified in advance and is set at an amount that prospective licensees would generally be prepared to pay. In that event, as Merges notes, the copyright holder will be unable to buy out unwanted uses and may have to accept less than the prescribed fee for prospective uses that she does want to transpire. But this multiple 
undergirds author self-reliance and expressive diversity, especially as compared with the alternative of no copyright. ${ }^{249}$ There is little evidence, if any, that a finely tuned pricing system, built upon a broad proprietary copyright, would direct investment to diverse audiences any more effectively than a more balanced copyright regime.

As noted above, the second respect in which the democratic paradigm diverges from Professor Goldstein's approach is that the democratic paradigm takes far more seriously the costs of a broad copyright monopoly. As a result, it supports a copyright that, while still relatively strong, is considerably less monolithic than his model. Put in economic terms, the democratic paradigm entails the transfer to copyright holders of sufficient consumer surplus to accord authors and publishers, not only a bare incentive for the production of creative expression, but also substantial room for risk taking and independence

taker problem would not generally be present where the liability nule takes the form of an ex post determination of the required license fee. whether on an individualized basis. as in a court's or arbitrator's damage award, or an industry-wide basis, as where government rate selting inbunals are authonzed to prescribe across-the-board compulsory license fees after copynght holder and user groups cannot agree among themselves. In those cases, uncertainty reganding the fee amount and the prospect of considerable negotiation and adjudication costs would discourage frivolous claumants and encourage efficient bargainung See Ayres \& Talley, Solomonic Bargaining, supra note 247, at 1074-75 (contending that. like liabılity rules and split entitlements, uncertainty as to judicial outcome may induce private informatson disclosure and thus lead to efficient bargaining). This would especially be the case with respect to indusiry-wide compulsory license fees, where the possibilities for tailored liability based on the privale information of any individual party are minimal. Accordingly. contrary to Merges's clam that property rules are most conducive to the establishment of collective licensing institutions that make barganing possible in the face of high transaction costs, it would appear that the most fruitful regimes in that regard are those. such as that long in effect in Germany, that require industry-wide bargauning under the threat of admınistratıve determınation of binding "reasonable" license fees if no voluntary agreement is reached. See Adolf Dietz. Germanv, in I INTERnational COPYRight LAw AND PRACTICE, GER-66 to GER-67 (Paul Edward Geller ed , 1995) (describing provisions of German law regarding formation of such "general" agreements) This basic model of providing for voluntary negotiations under the shadow' of binding arbitration has now been adopted in the United States with regard to the public performance of sound recordings in certan digital audio transmissions, the public performance of nondramatic musical works in jukeboxes, the use of published nondramatic musical works and published pictorial. graphic, and sculptural works in noncommercial broadcasting, and secondary transmissions by satellite camers for pnvate home viewing See 17 U'S C $\$$ $114(f), 116,118,119(c)(2)-(3)(1994)$.

Merges misses the point by failing to see that the primary purpose of certan compulsory licenses might not be to overcome transaction costs, but rather to depnve the copynght owner of the possibility of preventing transformative uses. Armed with a right to exclude. copynght owners may refuse to license unwanted transformative uses or demand supracompetitive license fees that have the same effect See supra notes 33-42 and accompanying text. Such a proprietary regime frustrates copynght's fundamental goal of promoting expressive diversity (in the sense of subversive reformulation as well as product differentiation) Copyright's democratic purposes will often be better served by a system. such as the cover recording compulsory license, in which copyright owners are allocated more than adequate user surplus (as evidenced in part by their consistent willingness to license for less than the statutory ceiling), but are unable to prevent the transformative uses that are subject 10 the compulsory license. See infra notes $427-31$ and accompanying text. (Of course, such a system will have democracy-enhancing advantages over a formal property rule only if. as in the case of the cover recordings. the compulsory license fee is not set so high as effectively to preclude nonconsensual transformative uses.) Seen in that light. and contran to .Merges's claim, it is hardly evidence of the failure of compulsory licenses that negotiated cover recording license fees will typically be less than the statutory rate. See Merges, supra note 168. manuscnpt at 33-35 (describing cover recording compulsory license as undesirable, "subopumal liability nule" because copynght holders bargaining under its shadow typically receive less than statutory rate).

249. See infra Subsections IV.C.1-2. 
from government and private patronage. But the democratic paradigm stops far short of Professor Goldstein's position that copyright holders should be able to appropriate as much consumer surplus as possible, especially as applied to prospective users who wish to draw upon existing expression to create new cultural works. ${ }^{250}$ It posits that, given the deadweight loss and dangers of private censorship that are intrinsic to the copyright monopoly, the social costs of enacting that sweeping protection would be simply too high to permit such a step, especially when Professor Goldstein's proffered justification for such additional protection is a pricing system of questionable efficacy.

Professor Goldstein is not unmindful of the social costs of a broad copyright monopoly, particularly as far as the burden on transformative uses is concerned. ${ }^{251}$ But he relies too heavily on the idea/expression dichotomy as a mechanism for ensuring that, no matter how broad copyright's protection of expression, at the end of the day, subsequent authors will be able to borrow sufficiently from existing works to create their own. ${ }^{252}$ Copyright's dramatic expansion into areas that were once thought to be unprotectable ideas, a phenomenon supported by neoclassicism, greatly undercuts the force of this constraint. ${ }^{253}$ Professor Goldstein's attempt to characterize neoclassicism as democracy-enhancing thus ultimately depends on an attempt to place limits on the neoclassical market paradigm that turns out to be untenable. Copyright's democracy-enhancing objectives would be better served by an approach that unequivocally places them in the foreground, relying on marketplace economics as a means of important, but of limited utility, in achieving that end.

\section{ThE MINIMALIST CRITICS OF COPYRIGHT EXPANSION}

In the face of the failure to obtain judicial recognition of a First Amendment defense to copyright infringement, critics of copyright's expansion have sought to constrain copyright from within. While this attempt has its

250. See GOLDSTEIN, supra note $18, \S 1.13 .2$, at 1:39 (maintaining that U.S. copyright law reflects implicit principle that "a copyright owner is entitled to capture the full value that consumers attach to its works, and not just the minimum sum that it would require to support its investment"). Professor Goldstein appears to apply this principle to transformative as well as nontransformative uses. See supra note 239.

251. See, e.g., id. $\$ 1.14$, at 1:40 (noting that "[i]f copyright law is to promote the national culture and learning, it must allow subsequent creators to draw on copyrighted works for their inspiration and education").

252. Compare id. $\$ 1.14 .2 .2$, at $1: 47$ (asserting that "[c]opyright law withholds protection from ideas on the principle that the national culture would languish if creators had to pay tribute each time they employed on these basic building blocks"), with id. § 5.3, at 5:79 (contending that copyright owners' exclusive right to make derivative works, which "sometimes contain only the faintest trace of the underlying work," serves to direct owner investment in accordance with consumer preferences). See also GOLDSTEIN, supra note 21, at 19-21 (contending that while copyright "optimists," such as himself, recognize need for idea/expression dichotomy, it is copyright "pessimists." who have succeeded in installing compulsory licenses and fair use "safety valves" into copyright law). For further discussion of Professor Goldstein's treatment of derivative uses, see supra note 239.

253. See supra text accompanying notes 68-76. 
merits, in the absence of a robust theory of why and how copyright itself reflects First Amendment values, critics have generally failed to account for the ways in which a properly tailored copyright would suppor expressive autonomy and diversity. As a result, opposition to expansion has had little force. In addition, many critics have fallen back on approaches to copyright that are overly minimalist. ${ }^{254}$

The minimalist critique has taken several forms. Perhaps most intriguingly, some critics have, in effect, set neoclassicist expansionism on its head by considering copyright economics in the context of the marketplace for all social resources. Like the neoclassicist expansionists, they view copyright as a mechanism for using the market pricing system to move resources to the uses for which consumers are most willing to pay. But in contrast to the expansionists, neoclassical minimalists insist that the market for copyrightable works is only a small part of the allocative efficiency matrix. In this view, while a broad proprietary copyright may lead to the mix of expression desired by those consumers who wish to buy expression, it will draw resources away from nonexpressive productive activity, resulting in an inefficient allocation of social resources overall. ${ }^{255}$ Indeed, for neoclassical minimalists, even a far more limited copyright, designed to achieve expressive diversity through a balance of incentive and access, may fail the test of allocative efficiency. As Glynn Lunney has recently stated:

More variety in works of authorship must mean less of something else. Because the production of additional works of authorship is not inherently more valuable than any other potential use of society's resources, justifying copyright requires some determination that society will benefit more from devoting additional resources to creating works of authorship than from the alternative investments to which the resources would otherwise have been devoted. ${ }^{236}$

As a result, argues Professor Lunney, copyright should provide only that degree of protection that would lead individuals to expect roughly the same price for their talent and resources whether invested in expressive or nonexpressive products that are equally sought by consumers. ${ }^{257}$

Other critics adopt a minimalist interpretation of the traditional copyright incentive rationale in order to question the necessity for copyright. They would

254. Some critics have also misdirected thesr attack on copynght expansion by laying the blame for expansion on natural rights theory and Romantucism. See supro nole 97

255. See ARNOLD PLANT, Economic Aspecls of Copyright in Books. in SElECTED ECONONIC ESSAYS AND ADDRESSES 57, 72 (1974); Roben M. Hun \& Roben M. Schuchman. The Economic Rationale of Copyright, 56 AM. ECON. REv. 421, 425, 430 (1966); Lunney. supro note 30; see also KAPLAX, supra note 68 , at 75 (asserting that overprotection "may concelvably run the nsh of attracting too much of the nation"s energy into the copyright-protected sectors of the cconomy")

256. Lunney, supra note 30 , at 655 .

257. See id. at 600,656 . 
scrutinize separately each type of original expression and would withhold copyright protection for that expression absent convincing proof that protection is required to induce its production and dissemination. ${ }^{258}$ Moreover, even if protection is to be accorded, these minimalist critics favor a copyright that provides just enough incentive for production and, possibly, dissemination, but no more. ${ }^{259}$ As Stewart Sterk puts it: "[F]rom an efficiency standpoint, copyright is justifiable only to the extent that copyright protection is necessary to induce additional creative activity."260 Accordingly, unless authors of a specific category "need copyright protection to induce them to create," no protection should be accorded. ${ }^{261}$ On this theory, Sterk argues that copyright should be unavailable for persons, such as commercial photographers, who are commissioned to produce their work, or even for anyone who would create a work without consulting with an attorney regarding formal requisites to obtain protection. ${ }^{262}$

As applied to the controversy over the proper scope of copyright in the digital network environment, the minimalist position has led some critics to a utopian vision of a world without copyright, where we all would be free to engage in collaborative, creative play. These critics believe that little or no copyright incentive is required to encourage creative activity and interaction on the Internet and, therefore, that copyright as we know it is not needed in the digital world. ${ }^{263}$ David Lange presents that view in a recent essay that hails digital technology as our Messiah, liberating us not only from copyright, but also from the constraining figures of societal authority, linear thought, and verbal language. ${ }^{264}$ In the digital world, muses Lange, our notion of intellectual "property" and our bourgeois "obsession" with "[p]lagiarism, attribution, distortion, truncation, mutilation, and the like,"265 will give way to an ethic of mutual gift-giving. ${ }^{266}$ "Perhaps," Lange concedes, "there will be room for encouragement of productivity and for appropriation of investment ...."267 Such a scheme would have to operate, however, under

258. See, e.g., Stephen Breyer, The Uneasy Case for Copyright: A Study of Copyright in Books, Photocopies, and Computer Programs, 84 HARV. L. REV. 28!, 322-23 (1970) (concluding that "the basic case for copjright protection for books is weak" and arguing that this "suggests that a heavy burden of persuasion should be placed upon those who would extend such protection," including extending protection against photocopying and to computer programs); Sterk, supra note 30, at 1205, 1209, 1213-15 (arguing that copyright incentive should be limited to inducing creative activity).

259. See, e.g.. Sterk, supra note 30, at 1205, 1209, 1213-15 (suggesting that copyright incentive should be limited to inducing creative activity).

260. Id. at 1213 .

261. Id.

262. See id. at 1214 (opposing protection for commercial photographers); id. at 1224-25 (opposing elimination of copyright notice requirement).

263. See supra note 12 and accompanying text.

264. See Lange, supra note 9, at 148, 150.

265. Id. at 144.

266. See id. at 148,151 .

267. Id. at 151 . 
the overriding principle "that anyone who wishes will be free to play in the fields of the word." 268

Somewhat more moderately, other critics would make room for some form of copyright in cyberspace, but would insist on maintaining in the digital network environment the same "free use zones" that have arisen in the hard copy world. ${ }^{269}$ These critics would insist that copyright not extend to personal and various noncommercial uses. They argue that remote digital reading, listening, viewing, and even electronic transmission of coptes for personal use, should not infringe copyright. ${ }^{20}$

The critics' various minimum positions suffer from a number of fundamental flaws that would lead to an overly truncated copyright. To the extent that minimalists view copyright entirely through the lens of allocative efficiency, they ignore copyright's constitutive role in underwriting the conditions for a democratic society, a social benefit that can neither be measured nor reflected in terms of consumer purchasing decisions." Copyright serves to suppon a system of self-reliant authorship. expressive diversity, and the dissemination of information that. given its vital importance for democratic governance. is and should be subsidized, at least to some extent, at the expense of nonexpressive production.

In this regard, many of the minimalist critics, it seems, have overlooked copyright's structural function. As I will discuss in the next Part, copyright does not serve merely to induce a greater quantity of creative production. It also is designed to secure the qualitative conditions for creative autonomy and expressive diversity. Copyright supports a sector of creative and communicative activity that is relatively free from reliance on state subsidy, elite patronage, and cultural hierarchy. As such. copyright must aim to enable authors and publishers to appropriate a somewhat larger share of consumer surplus than that which would merely support a minimally adequate quantity of creative production. To fulfill its structural function, copyright must accord authors and publishers some additional wiggle room. in effect creating a public

268. Id.

269. See, e.g., Elkın-Koren, supra note 40, at 277 (asserting that users of expression disseminuted over digital networks must be allowed "to do the same things the are able to jo in a non-digitized environment"); Hamilton, supra note 12, at 631 (favonng construction of "free use zone in the on-line era" that will make "explicit what is already accepted practuce in a hard copy unwerse-that copynght ow ners do not have rights to prohibit individuals from browsing and borrowing their worh, "*. Litman, stupra note 3, at 41-43 (opposing copyright protection for digital brow'sing): Zimmerman. supra note 3. at s0S (notıng public interest "in maintaining some approximation of our current cheap and simple acecss to topy righted works for research, scholarship and pleasure").

270. See infra text accompanying notes 399-401

271. My point that the metric of consumer purchasing decisions is inadequate to measure copynght, social benefit may be supported either by: (I) an economes-based argument that. given marhet falure arising from the public good characteristics of copynght's social benefit. individual purchising decisions do not reflect its true value; or (2) the idea that copyright's social benefit is an "incducibly soctal good" whose value derives from fundamental collectuve interests, rather than an aggregation of individual preferences. See supra note 44. 
subsidy to ensure author independence from patronage and to make possible a greater degree of risk taking, while still encouraging productive uses of existing works. Put in economic terms, the condition of self-reliant authorship is itself a public good that must be factored into the copyright equation.

Some critics also exhibit an impoverished view of copyright's production function. Those who call for a copyright-free cyberspace rely heavily on the indisputable fact that Internet discussion groups, featuring a wide open exchange of ideas on a broad spectrum of topics, have proliferated with little apparent reliance on copyright protection or financial incentive. But there is no reason to assume that the creators of "sustained works of authorship"-books, articles, films, songs, and paintings, as opposed to simply conversations and bits of information-will generally make their work available over the Internet, or will create new cyberspace variations of such works, without some reasonable possibility of remuneration. ${ }^{272}$

Still other critics give insufficient weight to copyright's role in encouraging the dissemination of creative works, as opposed simply to creative production. ${ }^{273}$ Some authors may in fact create works without a monetary incentive. For example, university professors and others who look to writing scholarly articles as a means to communicate their ideas and enhance their prestige, more than as a direct source of financial remuneration, are generally pleased to have as wide a readership for such articles as possible. At first glance, such authors might even welcome a regime in which their work was freely copyable. But authors must generally depend on publishers to disseminate their work, and publishers generally require, at the very least, the possibility of recovering their costs in selecting, editing, marketing, and distributing creative works. ${ }^{274}$ Publishers need copyright protection to publish scholarly works, even if scholars might not need such protection to write them. ${ }^{275}$

Finally, many critics take insufficient account of the changes in copyright economics that will be brought about by digital technology. As I discuss in

272. See Ginsburg, supra note 3, at 1498-99.

273. See supra text accompanying notes $258-62$.

274. Digital network technology will enable authors to bypass publishers to some extent. A novelist, for example, might reach her prospective audience directly by making her work available on her own Web site. But for the most part, authors and audiences will still likely be dependent on intermediaries to select which works are most likely to appeal to certain audiences and to make those works known to those audiences. Without such digital publishers to fulfill these gatekeeping and marketing functions, audiences will be lost in the ever-expanding sea of material available over the World Wide Web and other digital networks.

275. The Second Circuit recently recognized this principle:

Ultimately, the monopoly privileges conferred by copyright protection and the potential financial rewards therefrom are not directly serving to motivate authors to write individual articles; rather. they serve to motivate publishers to produce journals, which provide the conventional and often exclusive means for disseminating these individual articles. It is the prospect of such dissemination that contributes to the motivation of these authors.

American Geophysical Union v. Texaco Inc., 37 F.3d 881, 895 (2d Cir. 1994). 
Part V, hard copy world "free use zones" cannot be applied to the digital world without radically undermining copyright incentives.

\section{THE DEMOCRATIC PARADIGM}

Copyright plays a central role in promoting public education and expressive diversity. But both the neoclassicist approach, with its treatment of creative expression as a "vendible commodity," and the minimalist critics" approach, with its vitiation of the copyright incentive, threaten to diminish that role. This Part lays the foundations for an alternative approach, one that better comports with copyright's appellation as an "engine of free expression."276 It offers a theoretical framework that seeks to articulate more precisely and more directly than have other commentators the ways in which copyright supports a democratic civil society. ${ }^{277}$ The democratic paradigm is hostile neither to economic analysis nor to neoclassicist insights regarding the operation of copyright markets. But the democratic paradigm makes clear that while copyright may operate in the market, copyright's fundamental goals are not of the market. In providing a theoretical framework for a strong, but limited copyright, the democratic paradigm aims to reinvigorate copyright's role in the "preservation of a free Constitution."

$I$ begin this Part with an examination of democratic theory underlying the paradigm. I then explain how copyright helps to foster a vibrant and participatory civil society, thus underwriting opportunities for collective selfrule in a representative democracy. Part V will describe and contrast the paradigm's possible doctrinal outcomes with those of neoclassicism and the minimalist critics.

\section{A. Democratic Governance and Civil Society}

The emergence of democratic institutions in Eastern Europe, coupled with our acute uncertainty regarding the continued vitality and viability of our own,

276. Harper \& Row, Publishers, Inc. v. Nation Enters., 471 U S. 539.558 (1985)

277. For another recent, and welcome, attempt, see Elkın-Koren. supra noic 40 See also David Ladd. The Harm of the Concept of Harm in Copyright. J. CopYright Soc' Y 421. 427-28 (1983) (refernng briefly to importance for democratic governance of author and publisher independence from state largess) Paul Goldstein has also underscored the relation between copynght and democratuc governance See GOLDSTEIs. supra note 18 , § 2.2.1, at $2: 10$. His blueprint for copynght. however. reflects less an effort to determine how the particular needs of democratic governance might shape copynght doctnne than his steu of copyright as a vehicle for directing investment and his underlyung premise that a broad. neoclassicist copyright fosters expressive diversity, a premise I dispute. See supra notes $237-49$ and accompany ing texl At the opposite end of the spectrum. Lyman Patterson and Stanley Lindberg have argued that copynght should be namowly tailored to the needs of a democratic citizenry for access to information See LYwAS

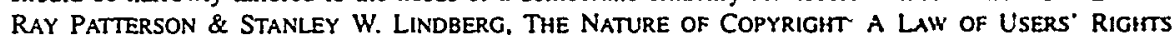
123-33 (1991). In so doing, they neglect copyright's role in underwrnung an independent sector of authors and publishers, a function that is critical to a democrauc civil society See infra Subsection IVC 2 a

278. See supra note 17. 
has brought renewed attention to the centuries old concept of "civil society."279 Civil society is the sphere of voluntary, nongovernmental association in which individuals determine their shared purposes and norms. It may include unions, churches, political and social movements, civic and neighborhood associations, schools of thought, educational institutions, and certain forms of economic organization. ${ }^{280}$ It incorporates formal and informal organizations, group identities and the shared purposes, histories, and discursive norms that hold groups together. ${ }^{281}$ As such, civil society also comprises the realm of public communication and discourse. ${ }^{282}$ This realm, which encompasses numerous forms of cultural expression, the mass media, and, increasingly, the proliferating welter of Internet user groups, bulletin boards, and Web sites, serves both as a fount of organizational life and as an independent manifestation of civic association, the space in which political, social, and aesthetic norms are debated and determined.

Contemporary theorists see a robust, pluralist civil society as a necessary, proactive foundation for democratic governance in a complex modern state. ${ }^{283}$ Civil society bolsters representative democracy in a number of ways.

279. See, e.g., BENJAMIN R. BARBER, JiHAD vs. MCWORLD 276-88 (1995); JEAN L. COHEN \& ANDREW ARATO, CIVIL SOCIETY AND POLITICAL THEORY (1994); ERNEST GELLNER, CONDITIONS OF LIBERTY: CIVIL SOCIETY AND ITS RIVALS (1992); DAVID HELD, MODELS OF DEMOCRACY 281-87 (1987); JoHN KEANE, DEMOCRACY AND CIVIL SOCIETY (1988); ADAM B. SEligman, THE IDEA OF Civil. SOCIETY (1992); Daniel Bell, "American Exceptionalism" Revisited: The Role of Civil Society, PUB. INTEREST, Spring 1989, at 38; Charles Taylor, Modes of Civil Society, 3 PUB. CulTuRE 95 (1990); Alain Tourainc, Triumph or Downfall of Civil Society, in I HUMAN. IN REV. 218 (David Rieff et al. eds., 1982); Michacl Walzer, A Better Vision: The Idea of Civil Society: A Path to Social Reconstruction, DisSENT, Spring 1996. at 293; Guyora Binder, Post-Totalitarian Politics, 91 MiCH. L. Rev. 1491 (1993) (reviewing COHEN \& ARATO, supra, and Francis FuKUYAMA, THE END OF HISTORY AND THE LAST MAN (1992)).

280. The precise definition and contours of civil society have long been a matter of some uncertainty and dispute. See John B. ThOMPSON, The MEDIA AND MODERnity: A SOCIAL THEory of the MEDIA 121 (1995). Hegel and other early theorists saw civil society as the realm of all social relations outside the state, including commercial and personal relations. See id. Many contemporary theorists, on the other hand, define civil society, to one degree or another, in opposition to the state, the market, and the family. See, e.g., BARBER, supra note 279, at 285 (labelling civil society as "mediating domain between private markets and big government"); COHEN \& ARATO, supra note 279 , at ix-x (describing civil society as sphere of democratic association and unconstrained discussion that lies separate from, but intertwined with, institutions of state power and economic production); HELD, supra note 279, at 282-87 (maintaining that democratic civil society is incompatible with unrestricted private ownership and private firm determination of political agenda); Walzer, supra note 279, at 300 (arguing that civil society may encompass institutions, like consumer cooperatives and worker communes, that function in market, but, as distinguished from capitalist firms, have their origins outside market).

281. See Binder, supra note 279 , at 1521.

282. For an extensive study of the role of the communications sector in civil society, see generally JOHN KEANE, THE MEDIA AND DEMOCRACY (1991).

283. See, e.g., BARBER, supra note 279 , at 276-88 (calling for reinvigoration of civil society as prerequisite for building global democracy); GELLNER, supra note 279, at 188-89 (arguing that pluralist civil society is necessary precondition to democratic government); HELD, supra note 279, at 281-89 (asserting that democratic, participatory civil society is necessary for viable democratic governance): KEANE, supra note 279, at 1-30 (seeing democratic civil society working in tandem with democratic state institutions as preferable altemative to state-administered socialism and neoconservative laissez faire economics); see also JURgen Habermas, THE STRUCtURAL TRANSFORMation OF THE PUblic SPHERE: AN INQUIRY INTO A CATEGORY OF BOURGEOIS SOCIETY 248 (Thomas Burger trans., 1989) (1962) (positing that public participation in process of formal communication conducted through civic associations may lead 
First, a robust, participatory, and pluralist civil society is the wellspring of what Robert Dahl, building on Alexis de Tocqueville's observations of antebellum America, has called a "democratic culture," a belief in and understanding of the democratic process that becomes embedded in the minds, habits, and character of a people. ${ }^{264}$ A democratic order depends upon a domain in which citizens develop the independent spirit, self-direction, social responsibility, discursive skill, political awareness, and mutual recognition. A state whose citizenry has not internalized these skills and values will rule through fiat and obedience, without any sense, so vital to our understanding of democracy, that its laws and social norms originate in the commitments of a self-governing polity. ${ }^{285}$

More concretely, a democratic civil society also fosters the citizenship skills and opportunities required for the explicit assertion of popular sovereignty over the apparatus of the representative democratic state. Popular sovereignty depends upon a citizenry imbued not only with the right, but also with the sufficient capacity and political competency, to pass judgment on decisionmakers, petition government officials, and influence political agendas. ${ }^{286}$ By participating in intermediate associational and communicative

to more deliberative and broad-based generation of publıc opınıon and to greater public control orer state institutions).

284. See Robert A. Dahl. A Preface to Economic Denocracy 30. 48-49 (1985)

285. Indeed, freed from any real constraint of popular accountability. such a state will inevilably trample even whatever abstract political rights it purports to accord its cilizens. According to Mlichael Walzer, even a totalitarian state cannot survive without some measure of willing cooperation on behalf of its citizens:

No state can survive for long if it is wholly alienated from civil sociely. It cannot outlast its own coercive machinery; it is lost. literally, without its firepouer The production and reproduction of loyalty, civility, political competence. and trust in authonty are neser the work of the state alone, and the effor to go it alone-one meaning of totalitananism-is doomed to failure.

Walzer, supra note 279 , at 301 .

286. Our system of representative democracy requires al once that state offictals be entrusted with near exclusive authority to make formal law and that popular sovereignty be the ultumate source of that authority. See Marci A. Hamilton, Power. Responsibilin; and Republican Democrats. 93 MiCn L REV 1539, 1539-40 (1995); Frank I. Michelman, Law's Republic. 97 YALE L.J 1493. 1500-03 (1988) The civil society model insists that in order for popular sovereignty to serve as a source of authoniy for formal law: citizens must possess a certain capacity and will to influence politics. It emphasizes as well that much democratic self-rule takes place outside the ambit of state insitutions and formal law. The civil soctety model vision of an active, politically competent culuzenry within the frameuork of a representauve democracy stands in contrast to the models of competitive elitusm. direct democracy. and anarchosyndicalism. The model of competitive elitism, associated with Max Weber and Joseph Schumpeter. posits a highly truncated view of popular sovereignty, in which, for all intents and purposes. the function of citizens in a modem representative democracy is limited to endorsing as their rulers one subset of the political elite rather than another. See HELD, supra note 279. at 143-85: JOSEPH A SCHI MPETER. CAPITALISM, SOCIALISM, AND DEMOCRACY 235-83 (1942). The direct democracy model. which has its roots in the theory and practice of the ancient Greek polis. requires acuve cilizen participation in formal governmental decisionmaking. See HeLD, supra note 279. al 13-28: PAUL A RAHE REPL'BLICS ANCIEST AND MODERN: CLASSICAL REPUBLICANISM AND THE AMERICAN REVOLUTION 28-54 (1992) It also tends to place a far greater emphasis on achieving consensus and on the subordınation of pnvate interest to the common good than does the civil society model. See Walzer. supra note 279. at 299. 303 (masntainıng that democratic civil society requires men and women who are actuvely engaged, but only "intermittently 
networks, citizens discover, refine, and articulate their interests, enabling them to vote with deliberative judgment and petition government officials with greater effectiveness. ${ }^{287}$ They also acquire organizational skill and see the possibility of accomplishing through common undertaking what they could not on their own, encouraging their participation in political association. ${ }^{288}$

Finally, civil society provides opportunities for collective self-rule outside formal institutions of government. It encompasses sites for associational activity in which citizens may determine their preferences and commitments and assert control over resources, without state direction. It is also the forum where policy and social norms are debated and determined, where preferences are aggregated, and where much of the political agenda is set. The norms and understandings that are contested and shaped in the associational and communicative contexts of civil society have a profound influence on the tenor of our individual and collective lives, often exceeding that of government action or policy. They not only percolate to public officials, but also pervade the myriad of nongovernmental settings in which we live our daily lives. As such, they govern us no less than formal law. ${ }^{289}$ Citizen deliberation regarding these norms and understandings, whether it takes places on shop floors, in Internet user groups, or through the mass media, is thus an intrinsic element of self-governance. ${ }^{290}$

\section{B. Civil Society, the State, and the Market}

Despite its largely self-constituted character, civil society is only partly autonomous from the legal and political institutions of government. Civil society requires from government massive material and institutional

virtuous," and who learn to articulate their own interests, rather than setting them aside in interest of consensus); see also JUDITH N. SHKLAR, AMERICAN CITIZENSHIP: THE QUEST FOR INCLUSION 5-6, 10-11 (1991) (distinguishing between "active" or "good" citizenship and fully devoted "ideal" citizen of classical antiquity). The anarcho-syndicalist model contemplates delegating formal lawmaking power to voluntary associations. See, e.g., PAUL HiRst, Associative Democracy: New FormS of ECONOMIC AND SOCIAL GOVERNANCE (1994) (calling for substantial devolution of power from state and market institutions to voluntary, self-governing associations which would then "become the primary means of democratic governance of economic and social affairs").

287. See DenNis F. Thompson. THE DEMOCRATIC CitIzen 60-62 (1970); see also Guyora Binder, What's Left, 69 TEX. L. REV. 1985, 2019-21 (1991) (discussing possibility for radical redefinition of personal identity and commitments and for enhanced political confidence and competence through participation in collective enterprise).

288. See 2 AleXIS DE TocQueville, Democracy IN AMEriCa 115-16 (Phillips Bradley, ed., Henry Reeve, trans., 1945) (1840).

289. See Michelman, supra note 286 , at 1531.

290. That is not to imply, moreover, that the civil society model requires rational deliberation or orderly progression towards consensus. In many ways, the opposite is the case. The civil society model allows, and indeed celebrates, a plurality of outlooks, identities, and lifestyles. The discursive element of civil society reflects this fundamental pluralism. It is more raucous cacophony than reasoned syllogism. It operates as much through the emotion, symbolism, and subliminal influences of art and mass culture as through a methodical presentation of issues. See infra Section IV.B. 
support. ${ }^{291}$ State intervention is required not only to sustain civil institutions, but also to ensure that they provide, rather than diminish, opportunities for democratic governance. While civil society generally nourishes democratic culture, it may also generate radically unequal power relationships. ${ }^{292}$ Intermediate associations and communicative structures need not be entirely egalitarian and democratic to fulfill civil society's constitutive potential. ${ }^{293}$ But an abundance of authoritarian social relations, whether in the employment, familial, interracial, religious, or educational contexts, may foster deference and servility rather than the culture of assertive autonomy upon which democracy rests. Workers with no job security or say in management, students and congregants who are trained to follow teachings without question, and persons who lack the means or opportunity to discern and articulate their interests can neither fully participate in democratic self-rule nor gain the political competency required for effective democratic citizenship.

Accordingly, an important role of law in a democratic state is to underwrite a robust, democracy-enhancing civil society through a combination of state involvement and private initiative. The state must provide educational and material resources for an active and politically competent citizenry. ${ }^{204}$ It must facilitate the democratization of associational and communicative frameworks to provide greater opportunities for citizen engagement and selfgovernment. Concomitantly, it must work to modify or eliminate social arrangements that undermine democratic citizenship while still leaving considerable room for "bottom-up" community organizing, education, and direction.

291. Michael Walzer provides several examples:

Families with working parents need state help in the form of publicly funded day care and effective public schools. National minonties need help in organizing and suslaining their own educational programs. Worker-owned companies and consumer cooperatives need state loans or loan guarantees; so do (even more often) capitalıst entrepreneurs and firms Philanthropy and mutual aid, churches and private universities, depend upon tax exemplions. Lubor untons need legal recognition and guarantees against "unfair labor practuces." Professional associations need state support for their licensing procedures.

Walzer, supra note 279, at 302.

292. See id.; see also COHEN \& ARATO. supra nole 279. al 255-98 (concluding thal although "Foucault is right in arguing that modem civil soctety is not equisalent to tts principles of freedom. equality, democracy, justice, rights, autonomy, and solıdanty." netther is it "equivalent to its strategies of domination and control").

293. See Walzer, supra note 279 , at 302-03

294. As Louis Brandeis said:

Under universal suffrage ... every voter is a pan ruler of the state Unless the rulers have. in the main, education and character, and are free men, our greal expenment in democracy must fail. It devolves upon the state, therefore. to fit its rulers for their task. It must provide not only facilities for development but the opportunity of using them lt must not only provide opportunity, it must stimulate the desire to avall of $\mathrm{dt}$.

Louis D. BRandeis, True Americanism, in Brandels on Democracy 25. 27 (Philippa Strum ed . 1995). see also JOHN STUART MILL, CONSIDERATIONS ON REPRESENTATIVE GOVERNMENT 25 (Cumn V Shiclds ed., Liberal Arts Press, Inc. 1958) (1861) ("[T]he most important point of excellence uhich any form of government can possess is to promote the vinue and inteligence of the people themseives.") 
The market presents both a threat and a promise to the democratic character of civil society. An unfettered market can give rise to gross disparities of power, resources, and associational capability, according the wealthy disproportionate opportunities to participate in civil life and to set political and social agendas. ${ }^{295}$ Significant state involvement may be required to prevent such market-based hierarchy. At the same time, however, the market underwrites opportunities for democratic citizenship that would not be available even in a benignly statist regime. In addition to promoting material well-being, market institutions support a degree of individual choice and possibilities for political autonomy and associational diversity that could not subsist within an all-encompassing bureaucratic state. ${ }^{296}$ Far from dispensing with market institutions, therefore, a democratic state should use them to enhance the independent, democratic character of civil society. The state may accordingly lend support to commercial activity and private accumulations of wealth in part to foster nonstate centers of power and associational activity. At the same time, it may define and allocate proprietary entitlements in a manner that diversifies private power structures, lessens dependency on state largess, and augments citizens' capacity for independent-minded participation in public discourse. ${ }^{297}$

295. See JOHN RAWLS, A THEORY OF JUSTICE 225-27 (1971) (noting that political liberties and democratic institutions "lose much of their value whenever those who have greater private means are permitted to use their advantages to control the course of public debate"). In the public communications sector, for example, those who have the capital to acquire or own a television station, newspaper, or movic studio, those who control advertising budgets, and those who have the wherewithal and propensity to respond to advertising have a far greater voice in determining the nature and content of disseminated expression than those who do not. See generally C. EDWIN BAKER, ADVERTISING AND A DEMOCRATIC PRESS (1994) (arguing that "advertising seriously distorts and diminishes the mass media's contribution to a free and democratic society"); Owen M. Fiss, Why the State?, 100 HaRV. L. REv. 781, 787-88 (1987) (describing constraints of public communications market). In the view of many commentators, unregulated capitalism may also threaten the democratic character of civil society by depriving workers of the matcrial security, autonomy, and practice in governance required for effective democratic citizenship. See, e.g., 4 JOHN STUART MILL, PRINCIPLES OF POLITICAL ECONOMY 775-941 (J.M. Robson ed., 1965) (1848) (decrying capitalism's stultifying impact on wage earner dignity and independence of thought and advocating syndicalist system of worker ownership and election of management); CAROLE PATEMAN, PARTICIPATION AND DEMOCRATIC THEORY (1970) (advocating participatory democracy within industry in order to enhance civic concern and political competence); William H. Simon, Social-Republican Property, 38 UCLA L. REv. 1335, 1339-40 (1991) (noting that republican and market socialist doctrine hold that market structure subverts democracy, in part, by forcing workers into "experiences of dependency (to use the republican term) and alienation (to use the socialist term) that preclude personal and political autonomy," and by reducing social actors to mere mass of consumers, undercutting the possibilities of association and democratic action). See also BARBER, supra note 279, at 242-45; Robin West, Taking Freedom Seriously, 104 HARV. L. REv. 43, 63-79 (1990) (discussing Václav Havel's critique of impersonal authority and subversion of individual responsibility in both capitalist consumer culture and totalitarian state).

296. See COHEN \& ARATO, supra note 279 , at 547 (maintaining that traditional welfare entitlements tend to create isolated clients of intrusive state bureaucracy, thus undermining personal autonomy and communicative and associational infrastructure of civil society); KEANE, supra note 279, at 4 (noting tendency of state-administered socialism "to encourage the passive consumption of state provision and seriously to undermine citizens' confidence in their ability to direct their own lives"); see also Rawls, supra note 295, at 272-73 (noting that market system provides citizens with "free choice of careers and occupation," but emphasizing that market system is not necessarily synonymous with capitalism).

297. Control over certain material resources may enhance citizens' political autonomy by frecing them from the corrosive influence of "pressing material need or beholdenness to patrons." Frank Michclman. 


\section{Copyright and a Democratic Civil Society}

Copyright is a limited proprietary entitlement through which the state deliberately and selectively employs market institutions to support a democratic civil society. Copyright law provides this support in two fundamental ways. First, through its production function, copyright encourages creative expression on a wide array of political, social, and aesthetic issues. The activity of creating and communicating such expression and the expression itself constitute vital components of a democratic civil society. Second, through its structural function, copyright serves to further the democratic character of public discourse. By according authors and their assigns a proprietary entitlement, copyright fosters the development of an independent sector for the creation and dissemination of original expression, a sector composed of creators and publishers who earn financial support for their activities by reaching paying audiences rather than by depending on state or elite largess. No less importantly, by limiting the scope of that proprietary entitlement, copyright constrains owner control over expression, seeking to preserve rich possibilities for critical exchange and diverse reformulation of existing works.

\section{Copyright's Production Function}

Copyright law is designed to foster the creation and public communication of original expression. Copyright protects "original works of authorship" that are "fixed in any tangible medium of expression ... from which they can be perceived, reproduced, or otherwise communicated." ${ }^{298}$ Although such works

Turelary Jurisprudence and Constiutional Propern, in LIBERTY. PROPERTY. AND THE FITL RE OF Constitutional Development 127, 158 n.16 (Ellen Frankel Paul \& Howard Dickman eds. 1990) (describing civic republican view of property but noting that it also has libertanan analogue), sec also HERBERT HOVENKAMP, FEDERAL ANTITRUST POLICY $49-52$ (1994) (discussing democralic balues inherent in antitrust enforcement); Akhil Reed Amar, Forty Acres and a Alule A Republican Theon of Whinimal Entitlements, 13 HARv. J.L. \& PUB. POL'Y 37 (1990) (anguing that "a munimal entulement to property is so important, so constitutive, and so essential for both individual and collective self-govemance" that state is entitled and, indeed, constitutionally obligated to provide each citizen with that entullement. if necessary by redistributing property held by other citizens). Entullements that assure decent housing. a secure job that offers a modicum of discretionary income, and access to informational and communicative networks support citizen ability and willingness to resist hegemonic extensions of stalc and prusic pouct See Rober $\mathrm{H}$ Anderson et al., Universal Access to E-mail: Feasibiling and Sociefal Implications (1995) (last vistted Oct 19. 1996) <http:/www.rand.org/publications/MR/MR650> (maintaining that universal access to e-mat is prerequisite to full participation in democratıc socıely): Míchelman. supro. al 130; see also Rıchard Krouse \& Michael McPherson, Capiralism. "Property-Owning Democracy:" and the W'elfare State. in DEsocracy AND THE WELFARE STATE 79 (Amy Gutmann ed.. 1988) (lising possible disinbulive measures)

298. 17 U.S.C. \& 102(a) (1994). The requirement of onginality means litle more than that the work cannot be a copy. Expression that exhibits a modicum of creatuvity and more than a trivial vanation from existing public domain works from which expression is borrowed will qualify. See Feist Publications $v$ Rural Tel. Serv. Co., 499 U.S. 340 (1991); Alfred Bell \& Co. v. Catalda Fine Arts Inc . 191 F 2d 99.102 (2d Cir. 1951). The fixation requirement rules out unrecorded conversation and extemporaneous speech. even if they are broadcast throughout the nation, unless they are fixed simulinncously with thesr broadcast See 17 U.S.C. \$101 (defining "fixed"). Conversely, copynght may subsist. from the moment of fixation. 
need no longer be made available to the public as a condition of federal copyright protection, the Copyright Act continues to maintain a system of incentives designed to encourage public communication. ${ }^{299}$ The stuff of copyright-fixed original expression and its public communication-lies at the heart of a democratic civil society. ${ }^{300}$

In fostering the production and dissemination of fixed original expression concerning a broad range of political, social, cultural, and aesthetic matters, copyright may promote the democratic character of civil society in two fundamental ways. First, the dissemination of such expression, no less than face-to-face dialogue, plays an auxiliary role: It is a fundamental building block of democratic association. Associations depend, for both their formation and operation, upon the exchange of information and ideas. Participants need to learn of and express their common interests, gain information about the association's founding principles and activities, and exchange their ideas about the strategies and issues that confront them. In all but the smallest, most geographically concentrated associations, this communication must generally take place among people who, because of distance, time constraints, and the number and anonymity of potential participants, cannot converse face-to-face. For that reason, Toqueville's observation that "hardly any democratic association can do without newspapers" ${ }^{\text {301 }}$ is equally applicable to modernday mass media, both electronic and print, and increasingly to digital network communication. The millions of fixed works of authorship that are regularly broadcast, distributed, and transmitted every day across such communicative systems are the lifeblood of civic association. The extent to which copyright promotes or inhibits their creation, dissemination, and reformulation is of fundamental importance to the democratic, participatory character of civil society.

A related aspect of copyright's auxiliary role is education. Democratic civil society and citizenship rely heavily on the widespread distribution of knowledge. For citizens to articulate their interests, participate in civic

in letters, books, sound recordings, recorded broadcasts, visual art, and works that are embodied, digital media.

299. See Robert A. Kreiss, Accessibility and Commencialization in Copyright Theory, 43 UCLA L. REV. 1, 2 (1995).

300. To be certain, the sphere of copyrightable subject matter is not coextensive with our system of free expression. Much public debate consists of speech that does not qualify for copyright protection, cither because it is not original or not fixed in a tangible means of expression or because the Copyright Act withholds protection from works created by federal employees within the scope of their employment. See 17 U.S.C. § 101 ("work of the United States Government"); id. \$§ 102(a), 105 (1994). But copyright does extend to a myriad of commentary that may have a direct or indirect impact on matters of democratic governance.

301. 2 DE TOCQUEVILLE, supra note 288, at 112. For an account of the central role of newspapers in the proliferation of grassroots political organizations soon after the founding of the Republic, sec JoYCE APPLEBy, CAPITALISM AND A NEW SOCIAL ORDER; THE REPUBLICAN VISION OF THE 1790S, at 55-56, 77-78 (1984); see also THOMPSON, supra note 280 , at $82-85,114-18$ (detailing ways in which communications media greatly enhances dispersed individuals' ability to act in concert). 
association, and engage in reasoned deliberation on public issues, they must "have access to the rich store of the accumulated wealth of mankind in knowledge, ideas and purposes." 302 Since effective, democratic education encourages independent thinking through active learning, the access to existing knowledge must involve an opportunity to reformulate ideas and transform expressive works, as well as simply to contemplate them. Copyright supplies a vital incentive for authors and publishers to contribute to the store of knowledge. But if drawn too broadly, it can also inhibit access and unduly burden transformative uses of existing works, thereby impeding public education.

In addition to its auxiliary role, public communication, much of which is underwritten by copyright, serves as an independent, critical component of civil society. Deliberation and robust debate are the essence of democratic culture. Indeed, democracy might be defined as a moral system in which those who are best able to convince their contemporaries through rhetorical skill, rather than win them over by bribes or brute force, are entitled to the greatest share of political power. ${ }^{303}$ In our age of mass media and electronic communication, much democratic citizenship consists not in face-1o-face dialogue or community organization, but rather in exchanging ideas about political, social, and cultural issues through television, radio, films, newspapers, books, music, art, and now multi-media CD-ROMs and the Internet. ${ }^{304}$ While such fora lack the intersubjective intimacy of face-to-face interaction, they are no less a locus of deliberative discourse. ${ }^{305}$ Indeed, they make up the primary space in our society where public opinion is forged and social norms are contested and elaborated.

302. JOHN DEWEY, LIBERALISM AND SOCIAL ACTION 52 (1963) Without saying so explicilly. Dewey was sharply critical of intellectual propeny regimes that reallocate exclussve nghts to ideas and expression He advocated the diffusion of leaming based on the model of the scienufie community. in which setenutic inquirers share their knowledge with their colleagues. See also JOHX DENEY. ISDIVIDT ALISS OLD ASD NEW 154-55 (1930). In one biting passage. Dewey appears to lay upon intellectual property much of the blame for the failings of democracy:

Back of the appropriation by the few of the matenal resources of sociely lies the appropnation by the few in behalf of their own ends of the cultural. the spintual. resources that are the product not of the individuals who have taken possession but of the cooperaluse work of humanity. It is useless to talk about the failure of democracy untul the source of its fallure has been grasped and steps are taken to bnng about that lype of social organization that will encourage the socialized extension of intelligence

DEWEY, LIBERALISM AND SOCIAL ACTION, supro. at 53.

303. As Michael Walzer notes: "Citizens come into the forum with nothing but their arguments All nonpolitical goods have to be deposited outside: weapons and wallets. Hilles and degrees " MIICHAEL. WALZER, SPHERES OF JUSTICE: A DEFENSE OF PLLRALISM AND EQT ALITY 304 (1983)

304. For an insightful discussion of the role of the mass media in public deliberation. see BEVA I. PAGE, Who Deliberates?: MASS MEdia IN MODERN DEMOCRACY (1996)

305. In fact, the act of fixing one's thoughts in a tangible medium of expression and the ate of reading. viewing, or listening to fixed expression may often involve greater thought and contetnplation than off-thecuff conversation. As John Thompson has noted, such "mediated quast-interaction can stimulate deliberation just as much as, if not more than, face-to-face interaction in a shared locale " Trovipsov, supra note 280. at 256. 
It bears emphasizing that the constitutive role of copyrightable creative expression in a democratic civil society is limited neither to works of authorship that explicitly address matters of political or social importance nor to those that present ideas in a rationally apprehensible manner. Many creative works have broad political and social implications even if they do not appear or even seek to convey an explicit ideological message. Literature and art may be subtle, but powerful, vehicles for attitude change or reinforcement. Even what may seem to be abstract, "pure" artistic expression may challenge accepted modes of thought and belie the efforts of governments or cultural majorities to standardize individual sensitivities and perceptions. ${ }^{306}$ For that reason totalitarian regimes have prohibited styles of art and music that might be seen as politically innocuous in other contexts-and for that reason a democratic polity committed to the dialogic interchange of independent-minded individuals must protect them from official or private censorship. ${ }^{307}$

The same is true with regard to works of popular culture. Our public discourse comprises a rambunctious, effervescent brew of spectacle, prurient appeal, social commentary, and political punditry. It is part entertainment, but as it entertains, it often reveals contested issues and deep fissures within our society, just as it may reinforce widely held beliefs and values. ${ }^{308}$ To be understood by their audiences, films, songs, and television programs must deal in the currency of prevailing practices, ideologies, and stereotypes, and in so doing must either reinforce or challenge them. ${ }^{309}$ Even seemingly innocuous cartoon characters, like Bart Simpson and Mickey Mouse, may be used to subvert (or reinforce) prevailing cultural values and assumptions-and with

306. See Marci A. Hamilton, Art Speech, 49 VAND. L. Rev. 73, 86-95 (1996) (maintaining that art is crucial to representative democracy because it challenges existing social relations, requiring fresh interpretation or reoriented reaffimation of status quo). For an intriguing account of the sociopolitical influences, statements, and ramifications of successive schools of architecture, see Jurgen Habermas, Modern and Postmodern Architecture, in CRITICAL THEORY AND PUBLIC LIFE 317 (John Forester ed., 1985). Even instruction in basic science may venture into politically contested territory. Consider Galilco's trial for heresy, the ongoing debate between evolutionists and creationists, and the claim by some that Western mechanical science and mathematics is implicated in cultural imperialism and environmental destruction. See 7 Will DuRANT \& ARIEl DuRANT, THE StORY of Civilization: THE AgE of Reason BEGINS 606-11 (1961) (describing Galileo's trial and conviction for espousing "heretical" idea that Earth revolves around Sun); Boyle, supra note 9, at 1531 (critiquing Western science); Williamson B.C. Chang, The "Wasteland" in the Western Exploitation of "Race" and the Environment, 63 U. Colo. L. REV. 849 (1992) (arguing that "eurocentric" patterns of thought, involving separation and conquest, are at root of environmental degradation and racial oppression); Peter Applebome, 70 Years After Scopes Trial. Creation Debate Lives, N.Y. TIMES, Mar. 10, 1996, at A1 (chronicling current efforts in several states to prevent teaching of evolution as fact rather than controversial theory).

307. See Alan Bullock, Hitler and Stalin: Parallel Lives 426-27 (1991) (describing totalitarian repression of certain forms of artistic expression); Hamilton, supra note 306, at 96-101 (presenting historical examples where art that was not overtly political threatened entrenched power structures).

308. The media treatment of the O.J. Simpson trial is a prime example of this mix of entertainment and elucidation.

309. See generally CHANNELS of DISCOURSE, REASSEMBLED (Robert C. Allen ed, 1992) (discussing. from various theoretical perspectives, manner in which audiences understand and interpret television). 
greater social impact than the most carefully considered Habermasian dialogue. ${ }^{310}$ The words, images, and sounds of commercial entertainment have a profound influence on our social mores and collective sense of reality. ${ }^{311}$ As such, the realm of popular culture serves, to a considerable extent, as both a resource and a playing field for the exercise of democratic culture and civic association.

In addition, the autonomous creation, critical interpretation, and transformation even of works of pure aesthetics or entertainment helps to support a participatory culture. Citizens who engage in these activities gain a measure of expressive vitality and independence of thought that may carry over into matters of more unequivocal public import as well. So long as the sources for pure aesthetics and entertainment are varied, such works may also foster an appreciation for diversity and a sense that elite cultural and social values may be confronted and contested. When taken as a whole, therefore, expressive works created for symbolic impact or broad audience appeal must, no less than copyright-supported political analysis, be seen as a vital par of democratic self-governance. ${ }^{312}$

310. As Jack Balkin has described The Simpsons, "Nothıng like good, cy nical humor that undermines everything honorable about American life." J.M. Balkın. Popultsm and Progressivism as Constituttonal Categories, 104 YALE L.J. 1935. 1937 (1995) (reviewing CASS R SLNSTEN. DevockaCY Avd THE PROBLEM OF FREE SPEECH (1993)). In that article Professor Balkin crituques (or, more aecuralely, ndicules) the notion that Habermasian rational deliberation on matters of unequivocal polutucal import can serve as the guiding ideal for democratic culture. See id. at 1936-42. 1958-63. Although I share in the substance of that critique, I disagree with his assessment that popular culture is itself the epttome of democrahc culture and thus should be valued for its own sake, see id. at 19.48 (arguing that popular culture "is not a sideshow or distraction from democratic culture, but the man eicni") My point is that popular culture is worthy of legal support because, on the whole, it has instrumental value to desnocratuc culture

311. See generally StUART EwEN \& Elizabeth EwEN. Channels of Desire Mass lMages and THE SHAPING OF AMERICAN CONSCIOUSNESS (1982). This is not to say that audiences are mere passise receptors of mass media entertainment. Communications and cultural studies theonsts have forcefully argued that audiences are active interpreters and rearrangen of mass culture See John Fiske, Brinsh Cultural Studies and Television, in CHANNELS OF DISCOURSE. REASSEMBLED. supra nole 309, al 28-. 292-321 (surveying British cultural studies examinations of "negotisted" and "opposituonal" readings of television programs and mass culture icons). Nevertheless. the mass media certainly play a major role in agenda setting. in presenting the material to which audiences react.

312. As the Fifth Circuit has cogently pointed out in rejecting the elaum that obscene expression should be ineligible for copyright protection. Congress fulfills its Copynght Clause mandate "[t]o promote the Progress of Science and the useful Ars" so long as "generally promotes (that) constitutional goal" Congress has not, need not, and should not require that "each copynghied work be shown to promote the useful arts." Mitchell Bros. Film Group v. Cinema Adult Theater. 604 F.2d 852. 860 (5th Cir 1979)

First Amendment scholars have engaged in considerable debate over whether "politucal speech." meaning speech that deals (preferably in a rationally apprehensible manner) with issues touching upon matters of government should be given greater weight than "arusuc speech." meanung speech thal deals with social, personal, or aesthetic issues, often in a symbolic manner. Compare ALEXANDER MEIKLEJOHN, FREE SPEECH AND ITS RELATION TO SELF-GOVERNMENT (1948) (arguing that since purpose of free speech is to educate voters, only political speech falls within ambil of First Amendment). and CASS R SL STEIN. DEMOCRACY AND THE PROBLEM OF FREE SPEECH 121-65 (1993) (favonng two-tuer First Amendment that recognizes primacy of political speech), with C. EDWIN BAKER. HUMAN LIBERTY AND FREEDOY OF SPEECH 31 (1989) (contending that "nonpolitical" speech should receive same level of protection as "poltical" speech). Scholars have also argued about whether giving political speech greater weight in the First Amendment context should mean that government should be more or less involved in seeking to promote a wealth and diversity of such expression. Compare SUNSTEs. supra. at 48-51 (favoring government 


\section{Copyright's Structural Function}

In addition to encouraging the production and dissemination of much of the expressive underpinning of civil society, copyright promotes the democratic character of public discourse. Copyright serves this end in two basic ways: It undergirds a sector of expressive activity that is independent from state and elite patronage and it sets limits on private control of creative expression. ${ }^{313}$

\section{a. An Independent Expressive Sector}

The public communication of fixed original expression will support a democratic civil society only if such expression is autonomous and diverse. A regime in which government administrators exert broad control over the content and dissemination of tangible expression will be unlikely to maintain viable civil institutions. A civil society in which private elites exert such control will be characterized by hierarchical domination, not democratic participation.

Copyright is vital to maintaining the democratic character of public discourse in civil society. By supporting a market-based sector of authors and publishers, copyright achieves considerable independence from government

involvement to "produce attention to public issues, and exposure to diverse views"), with Balkin, supra note 310, at 1964 (maintaining that Sunstein's two-tier system should require greater judicial scrutiny of government involvement in political speech). Often scholars who view the First Amendment as a protection against government incursion into individuals' possibilities for self-realization disfavor the distinction between political and artistic speech. See, e.g., BAKER, supra, at 31. In contrast, those who see the First Amendment as an instrument for promoting democratic governance generally favor lending greater weight to political speech, but seek, with considerable difficuity, to incorporate within the parameters of political speech at least that "artistic speech" that concerns social issues of fundamental importance. See. e.g., SUNSTEIN, supra, at I52 (including within the ambit of political speech, "all art and literature that have the characteristics of social commentary").

My argument might suggest that even those who see the First Amendment primarily as a vehicle for enhancing citizen capacity for democratic self-rule need not distinguish between political and artistic speech. Cf. Hamilton, supra note 306, at 86-95 (maintaining that art's challenge of status quo understandings is crucial to representative democracy and thus that art deserves same level of First Amendment protection as overtly political speech). Nevertheless, my thesis that copyright law serves primarily to promote democratic governance, and that it does so by encouraging the dissemination of artistic as well as political expression, does not necessarily support the equal treatment of political and artistic speech in the First Amendment context. While artistic speech does make a certain contribution to democratic govemance, it may be that political speech (whether broadly or narrowly defined) has a greater and more direct importance for democratic governance and thus should be treated differently in the First Amendment context.

313. Copyright may also promote the democratic character of public discourse by highlighting the value of individual creativity. Modern copyright arose from and continues to give legal expression to an Enlightenment understanding of individual agency, rationality, and transformative potency. See Netancl, supra note 97, manuscript at 40-42. By according protection to creators of original works of authorship, rather than simply to publishers who reprint long-existing works, copyright underscores the value of fresh ideas and of individual contributions to our cultural heritage. As such, it tends to undermine cultural as well as political hierarchies, thus contributing to the democratization of civil society. See Hamilton, supra note 12, at 617-18 (arguing that pressure, backed by threat of trade sanctions, on nondemocratic regimes to enforce copyright protection for U.S. works is, in effect, aimed at forcing greater democratization in such countries). 
administrators and private patrons who would otherwise meddle in expressive content. Though not dispositive, it will be helpful, first, to anchor this claim in the early historical development of modern copyright. In so doing, I hope to underscore both the print market's instrumental role in the development of a sphere of democratic public discourse and the Framers' understanding of that role in providing for federal copyright protection. I then discuss copyright's continuing part in promoting expressive plurality in the dawn of digitization. including the problem of market-generated hierarchical domination of public discourse.

Prior to the first modern copyright statutes in the eighteenth century, writers and artists were heavily dependent on royal, feudal, and church patronage for their livelihoods. ${ }^{314}$ This dependency undermined expressive autonomy and thwarted the development of a vital, frecthinking intelligentsia. ${ }^{315}$ As Voltaire described it: "'[E]very philosopher at court becomes as much a slave as the first official of the crown." 316

The patronage system also served to embed public discourse firmly within the hierarchical order of medieval and early modern Europe. During the Middle Ages, literature and art were commonly commissioned and controlled for purposes of public mystification. ${ }^{317}$ They were designed to impress upon their audience the dominant status of the patron, whether it be king, noble, or church. Later, within the framework of late Renaissance neoclassicism, the patronage system fostered a view of the arts as a "gentleman's calling," tailored to aristocratic tastes and far removed from common social experience and creative sensibility. ${ }^{318}$

It was not until the eighteenth century that there emerged a comprehensive sphere of public communication that was both independent of monarchy, aristocracy, and church, and capable of challenging their political and social

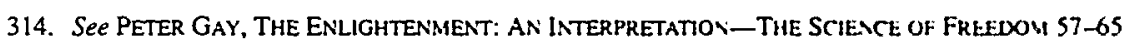
(1969); Herman Finkelstein, The Copyright Law-A Reappratsal. 104 U PA L RR: 1025. 1033-35 (1956).

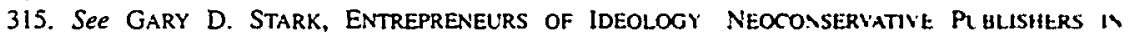
GERMANY, 1890-1933, at 3 (1981) (asserting that delayed iransition from patronage to propractary copynght system in Germany helps account for relatively late emergence of German intelligentsia)

316. GaY, supra note 314, at 63 (quoting Voltaire).

317. See James Curran, Communicalions. Power and Social Onder, in ClLT RE. SOCIETY s SO niE MEDIA 201, 203-10 (Michael Gurevitch et al. eds., 1982) (describing medteval Catholut Church's use of architecture, sculpture, paintings, stained glass windows, and books to uphold its power)

318. See HAROLD J. LASKI. THE AMERICAN DEMOCRACY 394 (1948) Lash mauntauns that thus Renaissance view of the arts persisted, to some degree, among the founding elite of the linted States. even though it did not actually reflect the creative temper of nascent Amencan culture See id at 395-100. see

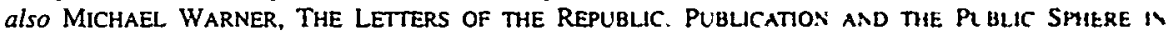
EIGHTEENTH-CENTURY AMERICA 132-38 (1990) (describing tension between republican view of pnnt and aristocratic concept of "polite" or "fine" art). Prior to the neoclassical pernod, popular and elite culture here intermingled to a greater extent. See PETER BURKE, POPULAR CLLTURE IN EARLY MODER EL ROPE 277 (1978) (noting that Shakespeare had played to noblemen and apprentices alike) It was not untul the spread of print and the "rediscovery" of popular culture among late eighteenth- and carly nincteenth-century Romantics, that the neoclassical disjunction between elite and popular culture was, to some degree. attenuated. See id. at 3-22. 
dominance. ${ }^{319}$ That sphere was largely made up of printed materialsnewspapers, pamphlets, and books-that received their primary financial support not from official patronage, but from readers and audiences. ${ }^{320}$ Freed from capricious and overbearing patrons, writers enjoyed a new, broad latitude to choose their own subject matter and find their own voice. ${ }^{321}$ The rapidly expanding reading public gradually shook off the influence of those who had used their control of art and literature to reinforce their positions of power. ${ }^{322}$ As it moved from patronage to market support, this sphere of communicative exchange generated, for the first time, a sense of "public opinion," the set of beliefs and norms elaborated in debate and discussion that citizens recognize as something they hold in common. ${ }^{323}$

The notion of public opinion, mediated by printed materials and emerging from autonomous citizen interaction outside of official, hierarchical organs, was central to early understandings of democratic civil society. ${ }^{324}$ It emerged with particular force in early eighteenth-century America, where this printmediated public space, outside any established political structure, defined the goals of the people and called government officials to account for deviating from them. In so doing, it centered the ultimate power of democratic rule in the autonomous institutions of civil society, which would direct and maintain a vigilant watch on elected representatives. Within democratic theory, it shifted the locus of citizen deliberation from the sovereign assembly of classical republicanism to the rough and tumble of the pen and the press.

Modern copyright arose with and contributed to the emergence of this democratic, print-mediated public square. ${ }^{325}$ Prior to the enactment of the

319. This is not to say that prior to the eighteenth-century elite control of literature and art was absolute and universal. Indeed, a largely oral popular culture coexisted alongside that of the political elitc. But this oral popular culture lacked the widespread political potency of print. See BURKE, stipra note 318, at 259-67 (describing print's emerging political influence in seventeenth- and eightecnth-century Europe).

320. For discussion of the economic conditions of authorship in England prior to and during the eighteenth century, see VICTOR BONHOM-CARTER. AUTHORS BY PROFESSION 5-32 (1978); see also John Feather, From Rights in Copies to Copyright: The Recognition of Authors' Rights in English Law and Practice in the Sixteenth and Seventeenth Centuries, 10 CARDOZO ARTS \& ENT. L.J. 455 (1992).

321. See GAY, supra note 314 , at 58-65.

322. See DAVIDSON, supra note 55, at $42-45$ (describing how growth, in late eighteenth- and early nineteenth-century America, of proto-mass audience for books, especially those, such as novels, that did not require official exegesis, eroded pulpit model of authority and led to "democratization of mind"); see also THOMPSON, supra note 280 , at 56-62 (discussing role of early print capitalism and nascent reading public in eroding power of Catholic Church and contributing to emergence of modern state in sixtcenthand seventeenth-century Europe).

323. My discussion of this sphere of print-mediated public opinion draws heavily upon Taylor, supra note 279, at 108-11; see also APPLEBY, supra note 301, at 76-78 (noting centrality of print in grassroots politics in early United States); HABERMAS, supra note 283, at $29-43$ (chronicling emergence of literary public sphere in England, France, and Germany); LARZER ZIFF, WRITING IN THE NEW NATION: PROSE, PRINT, AND POLITICS IN THE EARLY UNITED STATES 91 (1991) (discussing generally how "the democratization of print both promoted and was promoted by the democratization of society").

324. See Taylor, supra note 279, at 108-09; see also WARNER, supra note 318 (discussing preeminent role of contemporary understandings of print in republican ideology of eighteenth-century America).

325. This is not imply that this print-mediated public sphere was wholly dependent on copyright. For one, the first copyright statutes in Great Britain and the United States contained registration and deposit 
Statute of Anne of $1710,{ }^{326}$ the printing privileges that the Crown granted to members of the London Stationers Company had served as an instrument of centralized control and censorship. ${ }^{327}$ With the expiration of the notorious Licensing Act and the advent of modern copyright, however, authors gained a limited exclusive right to print copies of their works, with the express purpose of encouraging learning through the widespread dissemination of original expression. ${ }^{328}$ For the first time, authors could hope to earn their bread from the sale of their work to the public, and to do so through independent publishers who stood apart from the censorial arm of the state and the intermeddling of aristocratic and ecclesiastic patrons. ${ }^{329}$ As Oliver Goldsmith declared in 1760: "[Writers] have now no other patrons but the public, and the public collectively considered, is a good and a generous master." 330

requirements that, for all practical purposes. excluded from prolection the newspapers, magazınes. broadsides, and pamphlets that comprised a significant part of pnnt culture. See Clayton v Stone. 5 F Cas 999, 1003 (C.C.S.D.N.Y. 1829) (No. 2872) (denying copynght protection to newspaper financtal reports in part on grounds that daily newspapers" incompatubility uth copynght deposit and registration requirements indicated that Congress did not intend to include them withun seope of copynghtable "books") In addition, while the first British copynght statute was enacted in 1710. copynght was not secured by statute in colonial America. See Lyman Ray Pattersox. Copyright IN Historical Perspective 183 (1968). It was not until 1783, largely in response to a resolution of the Contunental Congress, that the stales began to enact copyright statutes, and the first federal copynght statute was enacted only in 1790 Set $d$ at 183-84. On the other hand, however, the common law recognized a nght to prevent unauthonzed publication of unpublished manuscripts. See Wheaton v. Peters, 33 U S. (8 Pet) 591.657 (1834) ("That an author, at common law, has a propeny in his manuscript. and may obtan redress agaunst any one who deprives him of it, or by improperly obtaining a copy endeavors to realize a prolit from its publication. cannot be doubted."). Less certainly, the common law may have also been seen to provide protection against unauthorized copying of published works. Compare Millar v Taylor. 98 Eng Rcp 201 (K B 1769) (holding that perpetual copyright existed at common law), whth How ard Abrams, The Histortc Foundation of American Copyright: Exploding the Myth of Common Low Copvright. 29 W AV VE L REV 1119.1156-71 (1983) (interpreting House of Lord's 1774 deciston in Donaldson v Beckes to stand for proposition that no copyright existed at common law). A measure of protecuon agansi ninous copying uas also provided by custom and agreement among colonial printers. See JOHN TEBBEL. I A HISTORY OF: BOOK PL BLISHISG IN THE UNITED STATES: THE CREATION OF AN INDUSTRY 1630-1865. at to (1972) In addition. technological and economic conditions gave the first to publısh a work a far greater advantage over latecomer copiers than would be the case following the development of the telegraph and mechanzed printing in the mid-nineteenth century and, even more dramatically. the possibility of instanianeous digital reproduction and distribution today. See, e.g.. Richard B. Kuelbowicz. The Press. Post Office, and Flow of News in the Early Republic, 3 J. EARLY REPUBLIC 255. 259 (1983) (noung that, because of significant ume involved in distribution and printing, people living on frontuer of early Republic could get newspaper from Philadelphia or New York as quickly as their local paper could obtan and pnit same information) Despite these protections, however, early Amencan authors. pnnters, and poliucal leaders recognized that without a federal copyright statute, the print market would not realize its potential for the diffuston of literature and information. See TEBBEL, supra, at 138-4! (noting lobbyıng efforts of Noah Webster. Thomas Paine, and others).

326. 8 Anne 19 (1710) (Eng.).

327. See PATTERSON, supra note 325 , at $28-41$ : Feather, supra note 320 , at $\$ 72-73$

328. The Statute of Anne, enacted by Parliament in 1710. w'as entiled "An Act for the Encouragernent of Leaming, by vesting the Copies of printed Books in the Authors or Purchasers of such Coptes. dunng the Times herein mentioned." 8 Anne 19 (1710) (Eng.): see also Patrersov, supra note 325. at 134-so (chronicling expiration of Licensing Act and enactment of Statute of Anne)

329. See Feather, supra note 320, at 472-73.

330. Letter LXXXIV, The Citizen of the World, in 2 COLLETtED WORNS OF OLIVER GOLOS IITH 3 il. 344 (1966). 
The emergence of a broad market in printed expression encouraged authors to challenge civic and religious authority, in part because rebelliousness and irreverence attracted paying readers. ${ }^{331}$ It also greatly enhanced print's democratic character and democratizing influence. The noncommercial literature of letters and political pamphlets in colonial America was ordinarily addressed to a small, educated elite and was composed in a florid style punctuated with classical references that had meaning only for a few. ${ }^{332}$ But the establishment of markets for literary works encouraged authors to write for a broader audience. ${ }^{333}$ Thus, the unprecedented best-seller success of Thomas Paine's pamphlet Common Sense in 1776 was due, in Paine's own estimation, in large part to his calculated effort to reach the common republican reader by using "language as plain as the alphabet" and by replacing classical references with Biblical references. ${ }^{334}$ This " "descent" of literature "'from the closets of philosophers, and the shelves of polite scholars" to the community at large, while a source of despair for some, was generally viewed as a necessary predicate for representative democracy, the health of which was seen to depend on an educated and informed citizenry. ${ }^{335}$

When the Framers drafted the Copyright Clause and the Copyright Act of 1790 , they took as self-evident that the diffusion of knowledge and exchange of view through a market for printed matter was a pillar of public liberty. ${ }^{336}$

331. See LANCE Bertelsen, The Nonsense Club: LITERATURE AND POPULAR CULTURE 1749-1764, at 260-61 (1986); Curran, supra note 317, at 222.

332. See Michael Schudson, Was There Ever a Public Sphere? If So, When? Reflections on the American Case, in HABERMAS AND THE PUBLIC SPHERE 143, 151 (Craig Calhoun ed., 1992).

333. By the end of the eighteenth century, the audience for print appears to have comprised the majority of U.S. citizens. See WARNER, supra note 318, at 14. The question of the size of the carly print public has preoccupied numerous historians and remains a matter of some controversy. See DAviDSON, supra note 55, at 55-61; THOMPSON, supra note 280, at 59; WARNER, supra note 318, at 14. Although some such studies are based on evidence of book ownership or writing skills, other historians point out that many persons in the eighteenth century could read, but not write, and that many who could not read, regularly listened as printed materials were read out loud in family, church, and social gatherings. See THOMPSON, supra note 280, at 60; see also KEANE, supra note 282, at $28 \mathrm{n} .23$ (depicting collective reading groups as "seedbed of revolutionary ideas and democratic forms of life" in eighteenth-century Germany and France). While most persons could not afford to purchase more than a book or two until well into the nineteenth century, libraries were a common and heavily used means of book circulation in the early years of the American republic. See DAvIDSON, supra note 55, at 27-28. Moreover, most eightecnth-century white Americans had ready access to newspapers, broadsides, and other print material. Not surprisingly, the reading public in late eighteenth-century America generally excluded black slaves (for whom it was illegal to read or write) and Native Americans. See id. at 56; WARNER, supra note 318, at 11.

334. Schudson, supra note 332, at 151 (quoting Thomas Paine, quoted in ERIC FONER, TOM PAINE AND REVOLUTIONARY AMERICA 83 (1976)). Not surprisingly, Paine was an outspoken advocate for according statutory copyright protection to authors. See TEBBEL, supra note 325, at 138.

335. ZIFF, supra note 323, at $\$ 2$ (quoting SAMUEL MILLER, A BRIEF RETROSPECT OF THE EIGHTEENTH CENTURY (New York, T. \& J. Swords 1803)); see also JAMES RALPH, THE CASE OF AUTHORS bY PROFESSION OR TRADE (facsimile 1966) (1758) (defending professional authors against charges of venality, but conceding that much commercial literature is of low quality).

336. See WARNER, supra note 318 , at 124-25. Typical of this widely held view was the pacan to the power of print in the inaugural issue of the New-York Magazine, published in 1790, the same year that Congress enacted the first federal copyright statute:

Those institutions are the most effectual guards to public liberty which diffuse the rudiments of literature among a people .... A few incautious expressions in our constitution, or a few 
They were fully immersed in a culture that identified print with republican government and resistance to tyranny. ${ }^{337}$ The Framers believed that a copyright-supported national market for authors' writings was vital to maintaining public vigilance against government encroachment, as well as fostering a democratic culture. ${ }^{338}$ As President Washington declaimed in his address to Congress in support of the first federal copyright statute, the promotion of science and literature would help to secure a

free constitution... [b]y convincing those who are entrusted with public administration that every valuable end of government is best answered by the enlightened confidence of the public; and by teaching the people themselves to know and value their own rights; to discern and provide against invasions of them; to distinguish between oppression and the necessary exercise of lawful authority. ${ }^{\text {iy }}$

Part and parcel of this vision was an understanding that democratic governance requires not simply the diffusion of knowledge per se, but also an autonomous sphere of print-mediated citizen deliberation and public education. The Framers well understood the dangers of patronage. They had seen first hand the transformation of the American print industry as it emerged, in the mid-eighteenth century, from its servile dependency on colonial government and church largess to become, with the support of a broad-based readership, a powerful and highly combative force in public affairs. ${ }^{\text {tan }}$ It was only by

salaries of office too great for the contracted feelings of those who do not haw the worth of merit and integrity, can never injure the United States, while literature is generally diffused. and the plain citizen and planter reads and judges for himself

WARNER, supra note 318, at 125 (quoting On the Means of Presening Public Lubern. New. YORh Mali. Jan. 1790). The view of print, literacy, and the diffusion of knowledge as a pillar of democratic governanic was shared by federalist and antifederalıst, poliucal elite and arisan, aluke See id at 122-32

337. See WARNER, supra note 318 , at 71, 122-32.

338. Copyright was not the only mechanism by which the Framers sought to achiese a nutional market for authors' writings. The new federal government also heivily subsidized new spaper delivertes by imposing preferential postal rates, levying postal charges on subseribers rather than printers, internuttently collecting subscribers' postal charges, providing free newspaper delwery among pnnters, and maintaining postal roads for both post office and prnters' private use. See Kiclbouicz, supra note 325, al 257-54, 266. 275. The importance of transportation networks for the diffusion of knowledge (as well, of course. lor other national political and economic objectives) also recesved expression in the Copynght Ait of 17\%, which accorded protection not only to books, but also to maps and navigatsonal charts See Aet of May 31,1790 . ch. $15, \$ 1,1$ Stat. 124,124 .

339. UNITED STATES COPYRIGHT OFFICE, COPYRIGHT IN CONGRESS 1799-1904. COPIRIGirt OFFIC BULLETIN No. 8, 115-16 (T. Solverg ed., 1905) (quoting U.S. Senate Joumul. Ist Cong 102-04,

340. See DAvidSON, supra note 55, at 16-30 (describing emerging. but uneicn marhel economy ot book publishing in early national period); LUCAS A. PONE. JR. THE FOt RTM ESTATE AVD THE CONSTITUTION: FREEDOM OF THE PRESS IN AMERICA 28-29 (1991) (depicting transformation of eighteenthcentury press); WARNER, supra note 318, at 67-70 (discussing manner in which pnnters. whose ctonomic viability was threatened by Stamp Tax, successfully galvanızed public opınıon against Tax by emphasızıng that it was affront to libeny of press). Government contract did not cease to become a major source of business for early national printers. But it represented only a portion of that business. and the struggiting new government was just as reliant on printers for the pnitung of money. laus, tracts. and otficisl proclamations as were printers on government revenues. See DAvidsos, supra note 55, at 21 . Pon L. supra, at $28-29$. 
maintaining their fiscal independence that authors and publishers could continue to guard public liberty. For the Framers, therefore, copyright's importance lay in its structural, as well as production, function. By underwriting a flourishing national market in authors' writings, copyright would help to secure authors' and printers' freedom from the corruptive influence of state, church, and aristocratic patronage.

The Framers' basic premises remain at the heart of copyright today. Without legal protection against ruinous copying, authors and publishers would be unduly dependent on state or private beneficence, with its attendant vitiation of critical autonomy and expressive diversity. While circumscribed government subsidies for the creation and dissemination of creative expression may be a valuable, democracy-enhancing measure of a modern democratic state, the widespread, systematic reliance of authors and publishers on such subsidies would ultimately bring the sphere of public communication within the web of state bureaucracy, stifling free expression. ${ }^{341}$ Alternatively, in a world with neither copyright nor massive state subsidy, authors would likely rely heavily on private patronage, forcing them to cater to the tastes, interests, and political agenda of the wealthy, rather than seeking a broader, more varied consumer audience. Copyright thus serves to support a robust, pluralist, and independent sector devoted to the creation and dissemination of works of authorship. As such, copyright constitutes an integral part of a system of collective self-rule in which the norms that permeate our social relations and undergird state policy are determined in the space of broad-based citizen debate, rather than by government or private fiat.

This is not to say that the Framers' understandings are directly applicable to late twentieth-century political, cultural, and economic conditions. Our public discourse is far more dissonant and eclectic than that envisioned by the Framers. The political elite of the early Republic abhorred expressions of ideological faction and generally disdained fiction and "light" entertainment. ${ }^{342}$ Such works, however, form a major part of our copyrightsupported discursive universe. From our perspective, the Framers' watchdog view of literature and the press also seems somewhat simplistic. Today's media conglomerates have attained an agenda-setting power that rivals that of state officials and, in the view of some commentators, undermines the democratic character of public discourse by skewing it towards those with the financial wherewithal to obtain access or buy advertised products. ${ }^{343}$

But this certain disjunction between Framers' suppositions and current conditions in no way contradicts my basic premise that copyright, at its core, continues to underwrite an independent expressive sector that is critical to

341. See infra note 346.

342. See DAVIDSON, supra note 55, at 40-42 (describing Framers' censure of fiction); CASS R. Sunstein, The Partial Constitution 20-24 (1993) (discussing Framers' efforts to contain factions).

343. See, e.g., BAKER, supra note 295; Fiss, supra note 295 , at 787-88. 
democratic governance. With regard to the nature and content of public discourse, as the civil society model attests, our conception of democratic governance has come to accept, and indeed celebrate, a diversity of outlook and interest that comports fully with the cacophonous outpouring of expression that makes up our symbolic realm. As discussed above, we have also come to appreciate the sociopolitical valency of much expression that is designed largely for audience enjoyment and appeal. It must be remembered, moreover, that even during what some contemporary commentators regard as the apex of eighteenth-century republican deliberation, editors routinely pledged to make their newspapers "entertaining" as well as "useful." ${ }^{3+4}$ Although we must recognize the vital importance of considered deliberation on issues of public policy, many copyright-protected works of so-called "pure" art, fiction, and entertainment also make a substantial contribution to the "democratic culture" that is central to a viable system of representative democracy. Accordingly, while our copyright market may encompass a wealth and diversity of expression not contemplated by the Framers, the basic principle is the same: To systematically subject authors' expression to the stifling grip of patronage would be inimical to a "free Constitution."

The problems of media concentration and market-based hierarchy are more troublesome, but these, too, do not belie the importance of copyright's structural function for a democratic civil society. My claim is not that copyright, by itself, constitutes a sufficient condition for expressive pluralism and diversity. Indeed, the democratic character of public discourse may well depend upon some measure of state subsidy and regulation to disseminate information and give a voice to persons and views that might othervise receive insufficient attention in an unregulated media market. 3 .s But even to the extent that other forms of state involvement may be necessary and desirable, copyright remains a vital component of our system of free expression. Most basically, whatever the limitations of the market for cultivating expressive diversity, an all-encompassing state-supported regime would ultimately be far worse. Even in a representative democracy, massive state involvement would undoubtedly present a serious impediment to expressive autonomy and freedom

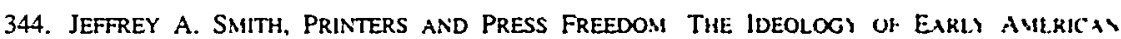
JOURNALISM 50 (1988).

345. Democratic governments regularly provide direct and indirect subsidies for vanous torns of cultural expression, ranging from individual grants to the funding of public broadeasting Ser Throsby. supra note 241, at 20-22. They also commonly impose selective resinctions on cultural industry structure and expressive content, including limtations on ownership concentration and requirements for a mimumum amount of public affairs programming and domestic production See generalls ERIC BARENDT, BroadCASTING Law: A CoMparative Study (1993) (surveying broadeast regulation in Great Britain. France, Germany, Italy, and United States). On the benefits for a democratic sociely of govemment subsidization of speech, see Marin H. Redish \& Daryl 1. Kessler. Goiemmem Substules and Free Expression, 80 MINN. L. REV. 543, 560-62 (1996); see also SUNSTEls, supra note 312, at 17-51 lialling for "New Deal for Speech," involving selective regulation and subsidy. to promote grealer medra coverage of public issues and greater public exposure to diverse view's) 
of information. Indeed, even limited state intervention may be used to further government officials' narrowly conceived political agenda and institutional goals-and given the ubiquity of government in modern life, the dangers of government indoctrination, favoritism, and suppression are certainly no less today than at copyright's birth. ${ }^{346}$ Accordingly, even if some state intervention is a necessary counterweight to market-based hierarchy, a strong, self-reliant expressive sector whose roots are outside the state still constitutes an indispensable ingredient of representative democracy. ${ }^{347}$ It is that expressive sector-both a watchdog and an independent, nongovernmental site for collective self-rule-that copyright serves to support.

A copyright-supported market would also enhance expressive pluralism and diversity to a greater extent than an expressive sector that relied heavily on corporate patronage. Like their aristocratic and ecclesiastic antecedents, corporate patrons are notorious for supporting expression that furthers their own objectives at the expense of artistic autonomy and diversity. As numerous studies have concluded, corporations regularly eschew avant-garde or controversial expression, tending rather to support cultural production that reflects mainstream interests and tastes, as befits a vehicle of public relations. ${ }^{348}$ Indeed, given their inherent conservatism, corporate patrons prefer to support art that has already been evaluated and approved for funding by the federal government, thus augmenting the danger of an official, government-established art that leaves little room for nonconforming views. ${ }^{349}$

To be certain, a copyright market dominated by media conglomerates may also exhibit a certain centripetal force. As noted above, given market dictates and institutional risk-averseness, media conglomerates share, at least to some extent, corporate patrons' proclivities toward prosaic and safe products. ${ }^{350}$ But the copyright market also contains room for highly innovative and provocative expression, as well as that targeted for specialized or minority audiences. ${ }^{351}$ Significantly, copyright's fundamental capacity to support

346. See Redish \& Kessler, supra note 345, at 562-63; see also LUCAS A. POWE, AMERICAN BROADCASTING AND THE FIRST AMENDMENT 108-61 (1987) (detailing repeated political favoritism in FCC regulation of broadcast media).

347. For an intriguing "public service model" of communications, centered in the development of pluralist, nonstate, but not fully market-based communications systems, see KEANE, supra note 282, at 150-62.

348. See, e.g., Crane, supra note 244, at 151-52 (canvassing studies); Rosanne Martorella, CORPORATE ART 67-91, 98-102, 179-83 (1990); Victoria D. Alexander, Pictures at an Exhibition: Conficting Pressures in Museums and the Display of Art, 101 AM. J. SoC. 797, 801-02, 822 (1996) (discussing conflicting pressures placed on museums to display various kinds of art by different social groups).

349. See Hamilton, supra note 306 , at 115.

350. See supra text accompanying notes $243-44$.

351. See CRANE, supra note 244, at 57, 59-60 (discussing continued contribution of independent recording and film companies in face of increased concentration and domination of major studios); DiMaggio, supra note 244 , at 440 (discussing role of independent media firms in producing innovative products). 
expressive diversity will likely grow dramatically in the digital age. The ease and low cost of digital production and dissemination has the potential of enabling authors, for the first time, to communicate directly with audiences throughout the world. As a result, many authors will be able to bypass media conglomerates, creating a copyright market characterized by an even greater multiplicity of view. ${ }^{352}$

This newfound freedom will not be realized without copyright protection, however. As several commentators have noted, in the absence of copyright, authors who seek remuneration for their work will be heavily dependent on vendors who, in effect, distribute creative expression for free in order to sell services, advertising, and ongoing customer relationships. ${ }^{353}$ Such a scenario could have dire consequences for expressive autonomy and diversity. For one, such value-added vendors are likely to be large firms with established delivery networks and the capacity to deliver ongoing services, thus leading back to the problems associated with media concentration. In addition, vendors who provide content simply as an adjunct to advertising and services will select (and alter) content on the basis of what will best sell advertising and services, not on the basis of what they think audiences will want to receive. This may seem to amount to the same thing, as the more people that want to see the content, the better it can be used to sell the related products. But often the content deemed best suited to selling the related products is not what audiences would otherwise pay to receive. As has been convincingly demonstrated with respect to television advertising, broadcast content tends to be weighted toward specific advertiser needs, such as putting audiences in a buying mood and offering attractive lead-ins to commercials, ${ }^{354}$ and targeted towards audience segments that are likely to buy advertiser products. ${ }^{355}$ Expressive content broadcast over the air is consequently less diverse and creator autonomy far more constrained than in sectors where consumers buy creative works directly. ${ }^{356}$ In short, the "patronage" of advertisers and bundled service providers would be no less constraining than that of contemporary corporate

352. See Elkin-Koren, supra note 40, at 256-58: Volokh. supro nole 21. at 1836-38

353. See, e.g., Barlow, supra note 21, at 128-29: Dyson, supra note 21. at 137-38 For what, to my mind, is an overly sanguine view of this possible development, sec Jessica Lutman. Revising Copinght Law for the Information Age, 75 OR. L. REV. 19, 29 (1996) (questuoning necessily of copynght incentuve given content provider ability to find different ways of charging for value. including adventising and complementary services); Tom Palmer, Intellectual Propern. A Non-Posnerian Law and Economics Approach, 12 HAMLINE L. REV. 261, 289-91 (1989) (same)

354. For examples and discussion, see BAKER, supra note 295. al 62-69. MIICHAEL SCIL DSOS. ADVERTISING, THE UNEASY PERSUASION 209-18 (1984); Les Brown. Sponsors and Documentanes, in The COMMERCIAL CONNECTION: ADVERTISING AND THE AMERICAN MASS MEDIA 265 (1979)

355. See TODD GITLIN, INSIDE PRIME TIME 208 (1983) (notung that adverising agencies began focussing on audience composition in early 1970s): OWEN \& WILDMAN, supro note 243. al 3-4 (discussing creation of target audiences by broadcasters).

356. See OWEN \& WILDMAN, supra note 243, at 101-50 (noting that content providess congental bias against minority tastes and in favor of large audiences' tastes is exacerbated in media characterized by firm concentration and in media supported by advertising). 
givers and seventeenth-century aristocrats. ${ }^{357}$ Without some copyright protection, much of the Internet's potential for promoting a democratic civil society will not be realized.

\section{b. Imposition of Limits}

A copyright constructed in accordance with the democratic paradigm would enhance expressive pluralism and diversity, not only by supporting an independent expressive sector, but also by imposing limits on the proprietary control over cultural works. That imposition of limits must be seen as a vital and integral part of copyright's structural function. No less than substituting paying audiences for patrons and service vendors, it is an important means by which the state may diversify communicative power structures without undue involvement in expressive content.

At present, much media conglomerate power derives from the ability to select, market, and distribute newly created expressive works. As a result of copyright expansion, however, such power also constitutes an unprecedented ability to control the deployment of existing expression. ${ }^{358}$ Media entities typically exercise that control to prevent any controversial use that might run contrary to their corporate image or threaten the salability of their expressive products. ${ }^{359}$ In addition, in many instances prospective authors are unable or unwilling to bear licensing fees for creative, transformative uses of mediacontrolled expression. ${ }^{360}$ As such, expansive copyright owner control over existing expression may exacerbate the problem of market-based hierarchy. Given authors' needs to draw on the existing images, sounds, and texts that make up our cultural milieu, conglomerate control over existing expression would continue to subvert the democratization of public discourse even in a digital age in which many authors no longer rely on conglomerates to market and distribute new works.

As I will outline in the next Part, a democratic copyright would limit copyright owner control over transformative uses, thus serving, at least to some extent, to loosen media conglomerates' hold on public discourse. In so doing, it would accord subsequent authors greater latitude to adapt media images,

357. Cf. Margaret Jane Radin, Property Evolving in Cyberspace, 15 J.L. \& CoM. 509, 521-22 (1996) (labelling as "dystopic commodified vision" replacement of copyright with digital fusion of content and advertising).

358. See supra Section I.A.

359. See, e.g., Doreen Carvajal, What Is a Book Publisher to Do When a Parody Hits Home?, N.Y. TIMES, Feb. 12, 1996, at D1 (reporting that Crown Publishers cancelled contract to publish book that spoofed works of another, more popular author, also published by Crown); see also Campbell v. AcuffRose Music, Inc., 114 S. Ct. 1164 (1994) (confronting action by music publisher to enjoin rap parody of song in its repertoire after refusing to license parody); Walt Disney Prods. v. Air Pirates, 581 F.2d 751 (9th Cir. 1978) (confronting action brought by Disney to enjoin parody of Disney characters in counterculture comic book).

360. See supra note 42. 
sounds, and texts in ways that may challenge mainstream assumptions-like the counterculture parody of Mickey Mouse or the bootleg sale in American inner cities of "Black Bart Simpson" T-shirts. ${ }^{361}$ In allowing for such highly derivative but subversive reformulations of existing expression, copyright would further the goal of expressive diversity no less than when it encourages product differentiation among the original underlying works. ${ }^{362}$ It would provide greater opportunities for mass expression to individuals and groups that are marginal to the centers of cultural production, while still supporting a strong expressive sector that is outside the state.

Importantly, under the democratic paradigm this diversification aspect of copyright's structural function implements the view that the public domain is no less vital to a democratic civil society than is copyright's protection of original expression. ${ }^{363}$ The limits that copyright law imposes on copyright owner prerogatives are thus not simply a neutral ending point where copyright protection ends and some other proprietary right may begin. Rather, they are an affirmative manifestation of copyright's democracy-enhancing principles. They are a statement that, where necessary to further those principles, ideas and expression should be free for all to use.

Under the democratic paradigm, therefore, the limits to copyright's duration and scope represent the outer bounds not only of copyright protection, but also of other forms of private control over publicly disseminated expression. Copyright should serve to circumscribe the propertization of publicly disseminated expression, even as it grants a limited monopoly over the use of expression. As I will discuss further, ${ }^{304}$ the democratic paradigm would therefore bar digital content provider efforts to circumvent copyright's limitations through contract and appropriate the public domain.

\section{Summary}

Copyright, in sum, is a state measure that uses market institutions to enhance the democratic character of civil society. Copyright law accords a limited proprietary entitlement that underwrites democratic culture and citizenship in three ways. First, it promotes the creation and distribution of information and educational resources. In supporting a market for creative expression, copyright aims to increase and make widely available the store of knowledge required for effective citizenship and civic association. Second, it enhances civil society's participatory character. Through economic incentives

361. See Walt Disney, 581 F.2d 751; Rosemary J. Coombe, Objects of Properny and Subjects of Politics: Intellectual Property Laws and Democronc Dialogue, 69 TEX. L. REV 1853, 1865 (1991) (discussing Black Bart Simpson phenomenon).

362. See supra note 240 .

363. On the importance of maintaining a vibrant public domain. see generally Luman. supra note 9

364. See infra Section V.D. 
and a careful balance between exclusivity and access, copyright seeks to foster widespread citizen participation in public deliberation. Third, it supports the plurality, independence, and vitality of civil society's communicative sphere. By according authors a carefully tailored proprietary entitlement, copyright frees them from reliance on patronage and cultural hierarchy, while opposing market-based hierarchy and encouraging transformative uses of existing works. In that way copyright law hopes to generate diverse and autonomous contributions to our common discourse.

Significantly, the neoclassicist economic view of creative expression as a commodity and of copyright as a mechanism to further allocative efficiency, fails to account for copyright's role in democratic governance. The activities and transactions that copyright encourages are in, but not of, the market. Copyright's fundamental purpose is to underwrite political competency, with allocative efficiency a secondary consideration. Copyright employs a quasiproprietary regime to achieve its constitutive goals, but the exclusive rights that copyright law accords are meant to be defined and delimited as required to further copyright's democratic purpose. Too thin a copyright would diminish the incentive for autonomous creative contribution, but a copyright of bloated scope, and one that would treat creative expression as simply another commodity, would stifle expressive diversity and undermine copyright's potential for furthering citizen participation in democratic self-rule.

\section{Doctrinal Outcomes in the Digital Public Square}

With the advent of digital communications, copyright's role in a democratic civil society has become at once more prominent and more problematic. All indications are that, within the next couple of years, a vastly increasing percentage and number of expressive works will be created and disseminated via digital communication networks like the Internet. Such networks create possibilities for collaborative authorship, transformative uses of existing works, and easy, inexpensive, and instantaneous access to creative works that exceed exponentially the possibilities that are available with current matrices of hard copy and broadcast distribution. ${ }^{365}$ As noted above, the Internet also promises a far more diverse, decentralized system of distribution. It offers an arena in which authors and audiences can communicate directly and interactively on a global scale, with far less involvement of government and media conglomerates in the provision and control of content than exists today. ${ }^{366}$ Given these possibilities, many commentators see the Internet as a

365. See Ginsburg, supra note 3, at 1466-69 (discussing potential uses of digital networks and need for new understanding of copyright); Volokh, supra note 21 , at 1808-31 (discussing changes in various media resulting from digital technology).

366. See Elkin-Koren, supra note 3, at 401-04 (noting that digital networks may weaken or transform intermediaries who previcusly controlled information). 
new site for a revitalized democratic civil society. ${ }^{367}$ The Internet will increasingly constitute a space where ad hoc coalitions, many of which will transcend national borders, will join forces outside the centralized institutions of state and market that currently control much dissemination of information. ${ }^{368}$ Through the Internet the realm of public communication will become more democratic. It will become less a unidirectional flow of information from agenda-setting elite to common citizen and more a digital public square in which citizens engage in unstructured, untempered discourse, free from the hierarchies imposed by government bureaucracy and capitalist organization. $^{369}$

Some commentators see copyright as an obstacle to this digital democratization of public discourse. They argue that the properization of expression will inhibit the free exchange of ideas over the Internet and enable media conglomerates to maintain their hold over expressive content, access, and cultural and political agendas. ${ }^{370}$ These concerns are understandable. An overly expansive copyright may indeed have a chilling effect on democratic discourse. But copyright remains, by and large, the best means of remunerating authors while still fostering a large measure of creative autonomy. The solution to the critics' concerns, then, is not to do away with copyright. Rather, copyright must be defined and delimited in accordance with its constitutive purpose. It must be designed to underwrite a vital and independent expressive sector without unduly hampering access and the free exchange of ideas.

With these parameters in mind, this Part will briefly compare the neoclassicist, minimalist, and democratic approaches to the most troublesome areas of copyright and copyright-related expansion, with particular emphasis on their implications for the digital network environment. This Article previously surveyed four areas in which the expansion of copyright holder's exclusive rights have been particularly dramatic and controversial. ${ }^{371}$ These

367. See, e.g., id.; Howard Frederick. Computer Neniorks and the Energence of Globul Cival Socten. in GLOBAL NETWORKS: COMPUTERS AND INTERNATIONAL COMMINICATION 283. 283-95 (Linda Harasim ed., 1993) (discussing growth of nongovemmental organizations. peace movements. human nghts groups, and environmental preservation societies resulting from computer networking)

368. See Frederick, supra note 367, at 294 (staung that purpose of new allied computer networks is to circumvent information monopolies).

369. See Elkin-Koren, supra note 40, at 236-67 (discussing ways in which digital networks may decentralize meaning-making process and enhance ability of induiduals to participate effecuvely in soctal dialogue). See generally Volokh, supra note 21 (predicting that digital distribution will usher in era of "cheap speech," which will liberate authors and audiences from mass media content selection and. largely as consequence, will undermine arguments for government regulation of speech)

370. See, e.g., Barlow, supra note 21. at 85-86. 89-90 (arguing that copynght law was developed to convey forms and methods of expression entirely different from diguzed medium and fasonng system that puts fewer constraints on circulation and modification of expression in digual network environments). Lange, supra note 9, at 140-47 (discussing role of premodern ongins of copyright in resinctung dissent and new technological challenges to copyright and ideas of authorship): see also Elkın-Koren. supra note 40. at 268 (arguing that employing copyright in its present form may dimunish Intemet's capacily to decentralize social dialogue).

371. See supra Pan 1. 
include: (1) the lengthening of the duration of copyright protection; (2) the extension of copyright to personal uses; (3) the subjugation of transformative uses; and (4) the displacement of copyright by contract. I will now suggest, for each area of expansion, some likely differences in direction that the three approaches would support.

\section{A. Copyright's Duration}

As previously noted, ${ }^{372}$ Congress has lengthened the duration of copyright protection from its initial bifurcated period of 28 years under the 1790 Act (with a more common 14-year term since relatively few copyrighted works were renewed for a second term), ${ }^{373}$ to a bifurcated period of 56 years under the 1909 Act (with a more common 28-year term, given the relative rarity of renewal), ${ }^{374}$ to the author's life plus 50 years (with works made for hire enjoying a term of the shorter of 75 years from publication or 100 years from creation) under the 1976 Act. $^{375}$ Under the Copyright Term Extension Act, now pending in Congress and likely to be enacted, copyright protection will be once again extended, to the author's life plus 70 years (with 20 years added to the term for works made for hire as well). ${ }^{376}$

The lengthening of the copyright term appears to be less attributable to neoclassicism than are other areas of copyright expansion. Much of the force behind the durational expansion lies in the realpolitik of international copyright relations $^{377}$-and, historically, continental European natural rights approaches

372. See supra Section I.A.

373. See Act of May 31, 1790, ch. 15, § 1, 1 Stat. 124, 124.

374. See Act of Mar. 4, 1909, ch. $320, \S 24,35$ Stat. 1075, 1080-81. A Copyright Office study of the copyright renewal, completed in 1960, found that only about 15\% of subsisting copyrights were being renewed. See Barbara A. Ringer, Renewal of Copyright, in I COPYRIGHT SOCIETY OF THE UNITED STATES, STUDiEs ON COPYRIGHT 503, 617 (Fisher Mem. ed. 1963).

375. Copyright Act of 1976, 17 U.S.C. $\$ 302$ (a) (1994). Different terms apply to works created but not published or copyrighted before January 1, 1978, the effective date of the 1976 Act, and to works in which copyright already subsisted on that date. Id. \$§ 303-04. In addition, in 1992 Congress effectively lengthened the copyright term for many works created before 1978 by making copyright renewal automatic. The Copyright Renewal Act of 1992, Pub. L. No. 102-307, tit. I, \& 102(a), (d), 106 Stat. 264, 266 (codified as amended at 17 U.S.C. $\$ 304(\mathrm{a})$, (c) (1994)).

376. See H.R. 989, 104th Cong. (1995); S. 483, 104th Cong. (1995).

377. The 1976 copyright revision was designed in part to pave the way for accession to the Berne Convention, which provides for a general term of protection of the life of the author plus 50 years. See Berne Convention for the Protection of Literary and Artistic Works (Paris Act, 1971), Art. 7(1) [hereinafter Berne Convention]. The Berne term was nonmandatory until the Brussels Revision of the Berne Convention in 1948. See Sam Ricketson, The Copyright Term, 23 INT'L REV. INDUS. PROP. \& COPYRIGHT L. 753, 778, 783 (1992). More recently, the Agreement on Trade Related Aspects of Intellectual Property Rights, TRIPs, supra note 63, finalized in 1994 as part of the agreement amending the General Agreement on Tariffs and Trade (GATT), requires all members of the World Trade Organization (WTO) to comply with the minimum terms of protection set out in the Berne Convention, whether or not such countries are signatories of Berne. See id. art. 9, at 415 . In addition, under the so-called "Rule of the Shorter Term," in effect in many countries and encouraged by Article $7(8)$ of the Berne Convention, copyright protection is extended to foreign works only for the shorter of the term accorded in the country of origin or the term accorded to domestic works in the country applying the Rule. Under the Rule, American works enjoyed protection in most European countries for only 56 years, while domestic works were protected for the life of the author. 
to authors' rights have motivated the long terms, based on the author's life, that have increasingly become the international standard. ${ }^{37}$ On the other hand, Congress has used the concern for maintaining the United States's copyright industry trade advantage to lengthen the duration of our copyright protection even beyond that which would be required for the United States simply to comply with international standards and requirements. In particular, the United States provides longer terms than required by the Berne Convention, the Agreement on Trade Related Aspects of Intellectual Property Rights (TRIPs), or the European Union for photographers, creators of applied art, broadcasters, sound recording and film producers, and corporate authors. ${ }^{379}$ Even more strikingly, a recent amendment to the Copyright Act, ostensibly enacted to comply with TRIPs, provides for a seemingly perpetual right for performers and their assigns to prevent the distribution of bootleg recordings of live music performances, even though TRIPs requires only a term of fifty years from the performance. ${ }^{380}$

Neoclassicism lends unreserved support to the lengthened copyright term. Under traditional economic incentive theory, copyright's optimal term would be no longer (and no shorter) than that required to provide a sufficient

plus 50 years, or, in the case of Germany, beginning in 1965. for the life of the author, plus 70 years More recently, in order to achieve greater harmony among the copynght regimes of its inember stales, the European Union has directed its member states to enact copynght terms equivalent to that of Germany. the life of the author plus 70 years, and to apply the Rule of the Shorter Term to non-linion works See Council Directive 93/98, ants. 1. 7. 1993 O.J. (L 290) 9. reprinted in SwEet \& MAXWELL's EC INTEllectual Property Materials 29-34 (Anna Booy \& Audrey Honton eds. 1994) The direcuie has, in tum, sparked moves in Congress to increase the length of protection in the Untted States as well Sce Copyright Term Extension Act of 1995: Hearings on H.R. 989 Before the Subcomm on Courts and Intellectual Property, 104th Cong. (1995) (statement of Rep. Moorhead)

378. See SAM Ricketson, The Berne Convention for the Protection or LTterari avo ARTISTIC WORKS: 1886-1986, at 323 (1987).

379. The European authors' rights tradituon disunguishes between those worhs that cmanale from individual creativity and those that are seen as less creauve or more corporate endeavors. With the latter often being protected under noncopyright "neighboring nght" regimes. Reflecting this distinction, the Berne Convention and the Rome Convention (which governs certun netghbonng nghis) set the mumum temis of protection for photographers, film producers, creators of applied art. television broadcasters, sound recording producers, and performers at periods ranging from 20 to 50 years from publication. creation or fixation, as the case may be. See Berne Convention, supra note 377. art. 7: Intemational Convention for the Protection of Performers, Producers of Phonograms, and Broadcasung Organtzations at Rome, Italy. Oct. 26, 1961, 496 U.N.T.S. 43, art. 14 [hereinafter Rome Convention]. The EU Directuve stmularly provides for a 50 -year term for performers, sound recording producers, film producers, and brozdeasters and confers a 70-year term upon collective and corporate works These periods are all shonter than the life. plus-50 and 75-from-publication or 100-from-creation terms conferred under the U S Copynght Act, as are the periods of protection for such works required under the Agreement on Trade Related Aspects of Intellectual Property Rights (TRIPs), which came into foree in 1994 See TRIPs, supra note 63. an 99 (incorporating minimum terms of Berne Convention with respect to most works of individual authors). id an. 12, at 415-16 (providing for minimum 50-year term for works of authorship. other than photographs or applied art, term of which is calculated other than by reference to life of natural person). id. ant $14(5)$. at 415 (providing for 50-year minimum term of protection for performers and sound recording producers and 20-year minimum term of protection for broadcasters) Moreover. the proposed Copynghi Term Extension Act, with its 95-year term for works made for hire. would heighten this dispanty

380. Section 1101 was added to the Copyright Act on December 8. 1994. pursuant to the requirement set forth in Article 14(1) of TRIPs that performers be accorded exclusive nghis of tixation. reproduction and transmission of their performances. See TRIPs, supra note 63, ar. 14(1) 
possibility of return to induce the creation and dissemination of new works. Neoclassicism, in contrast, focuses more on the market for existing works than on the creation of new works. It holds that broad, fully transferable property rights are the best mechanism for putting existing works of authorship to their most socially valued uses. Neoclassicism, therefore, has no reason to extinguish the owner's copyright after a term of years. ${ }^{381}$ So long as a work is socially valued, that value will be reflected in the price for using the work and the work will be licensed and developed accordingly, thus achieving an efficient allocation of resources. To withdraw protection from a work that is still socially valued would defeat this objective. Continuing protection for works that have no remaining social value causes no harm since, by definition, no one wants to use such works anyway. ${ }^{382}$ Similarly, if anyone does want to use the work, the work still has a social value measured by the price the user would be willing to pay, and thus protection should continue to facilitate the system of pricing and allocation.

The only plausible neoclassicist limitation on copyright's term might come at the point of anticipated market failure. Copyright protection, the neoclassicist might say, should end at the approximate time when most works still have some social value, but when that social value has decreased to such an extent that transaction costs would likely exceed the price that would be paid for using most works. ${ }^{383}$ But with collective licensing and computerized tracking mechanisms that sharply decrease transaction costs, that time would be far off, if it would ever come at all. ${ }^{384}$

The democratic approach, in contrast, would build on traditional incentive theory to support a richer vision of the public domain. It would hold that

381. See, e.g., Landes \& Posner, supra note 144, at 361-62 (suggesting that, aside from positive tracing costs, which need not pose any serious problem, there is no reason in principle to limit copyright term); $c f$. Easterbrook, supra note 8, at $111 \mathrm{n.7}$ (justifying copyright's long term on principle that intellectual property should be treated just like physical property absent strategic bargaining and trucing problems that might arise from exclusive right to ideas); Meiners \& Staaf, supra note 117, at 924 (suggesting, on basis of neoclassicist property theory, that duration of patent rights should be perpetual like duration of title to land).

382. Accordingly, a neoclassicist would see no more reason to withdraw protection from such works than to require that the property right in a dime store pen be automatically extinguished when the pen has run out of ink.

383. See Landes \& Posner, supra note 144, at 361-62 (citing positive tracing costs as possible justification for limiting copyright term).

384. Computerized systems are already in place in some contexts. For example, the Copyright Office has initiated a project to enhance its online database of copyright registrations to include information about obtaining licenses and to provide for an online clearance procedure that would make it possible for users to ascertain the status and ownership of a work, to obtain permission to use the work, and to pay for the use. See U.S. Copyright Office, Copyright Office Electronic Registration, Recordation \& Deposit System (visited Aug. 31, 1996) <gopher://marvel.loc.gov/11/copyright>. Likewise, the Copyright Clearance Center and a number of technology companies, digital content providers, and computer network service providers have formed the "Electronic Rights Management Group" with the intent to promote widescale clectronic clearance, per-use billing, encryption, and tracking for content that is available over digital networks. See Copyright Clearance Ctr., Inc., Press Release, Information Industry Leaders Form Electronic Rights Management Group to Foster Commerce on the Internet, Oct. 31, 1995 (on file with author). 
works should at some point become a par of our common cultural heritage because they have considerable social value, not simply because of market failure. It would emphasize that copyright is a limited grant designed to foster the expressive diversity and citizen autonomy required for democratic governance, and that copyright's term of protection should be determined with that objective in mind. Copyright must be sufficiently robust to support a vibrant, diverse, and innovative sector for the creation and distribution of original expression. At same time, once copyright has given sufficient support to creative autonomy, copyright's constitutive objectives are better served by placing works in the public domain than by continuing to transfer consumer surplus to copyright owners. At that point, so long as public domain works are adequately available to the public, continued protection would place an undue burden on authors, all of whom borrow from existing works in creating new ones, and an undue cost on those who simply wish to read, see, or hear such works. Or, put in economic terms, once copyright's democratic goals have been substantially funded, consumer surplus is better allocated to subsidizing both transformative and nontransformative uses of existing works for a broad array of educational and cultural purposes.

To state the principle, of course, is not to say that it is susceptible to exact application. Especially given the variegation and fluidity of copyright markets, it is difficult, if not impossible, to determine with any degree of precision the term of copyright that would lead to optimum suppor for creative autonomy. while still allowing for sufficient user access. By all accounts, however, it seems clear that the current term provides more than sufficient support for an independent and diverse sector of authors and publishers, ${ }^{3 x s}$ and that, from the perspective of democratic governance, any further lengthening of the duration of protection would be undesirable and unwarranted. ${ }^{350}$ At the very least, the democratic approach would require that policymakers put copyright's constitutive goals at the forefront in seeking to determine an optimal copyright term. And it would seem, in this regard, that the relatively negligible and, possibly, fleeting trade benefits of lengthening the term would be outweighed by the resulting impairment of public access and expressive diversity.

That said, however, even once the initial democratic benefits of copyright have been obtained, a longer term, or at least some form of protection, may be warranted as an incentive to publishers to keep public domain works in circulation. ${ }^{387}$ To fulfill the democratizing potential of the Internet, large

385. See Nimmer, supra note 47, at 1416; Rucketson. supra note 377. at 783-84

386. While it might be desirable, in theory. to amend the Copynght Act to shorten the basic copynght term, such a step would be exceedingly difficult to achieve in practice. since. in addition to having to overcome domestic copyright industry opposition. It would run afoul of the current term of protection requirements of TRIPs and the Beme Convention. See supra note 379

387. The United Kingdom accords publishers of new edittons a 25-year nght to prevent unauthonzed facsimile copies of the typographical arrangement of said ediuons. See Copynght. Designs and Patents Aet 1988, §§ 1(c), 15, 17(5) (Eng.). 
numbers of public domain texts, music, art, and films should be translated into digital format and made available to online users. As we move from a system based on the dissemination of hard copies to one of online access to virtual libraries, book and record stores, video rental outlets, and jukeboxes, it will be in one sense more difficult, but in another much easier, to meet this objective of public domain availability. At present it requires a material amount of time, effort, and money to produce and store a digital version of a hard copy work. ${ }^{388}$ But once the digital version has been produced and stored on a computer server, it costs much less to make it available for ready online access to anyone with an Internet connection anywhere in the world than it would cost to publish and distribute a hard copy edition. ${ }^{389}$

Our challenge, then, must be to encourage the initial production and storage of digital versions of public domain works. Given the costs of such tasks and the ease with which digitized works may be further copied and transmitted by others, we can expect relatively few such digital "editions" without some protection against unauthorized copying, transmission, and display. Absent such protection, our efforts to make public domain works widely available in digital format will likely be stymied by the same public good and free rider problems that, if not for copyright, would plague creators and publishers of new works. Accordingly, despite likely objections from some minimalist critics, ${ }^{390}$ the democratic approach might well support the extension of limited copyright-like protection for those who "publish" public domain works in digital format.

As with democratic copyright, such protection would be circumscribed, both in scope and duration, as necessary to meet its objectives. It might accord, for a limited time, a person who makes a digital version of a public domain work the exclusive right to copy that digital version and to transmit and display the underlying public domain work over a public computer network. The right would extend only to literal or near-literal appropriations of at least a substantial portion of the work. In order to promote (and, in effect, cross-

388. Given the considerable expense of converting hard copy works to digital format, it is unlikely, at least in the near term, that more than a small percentage of hard copy collections will be so converted. See CRAwFord \& GORMAN, supra note 21 , at $90-96$ (discussing high cost of digital conversion and dispelling notion that all or substantial portion of hard copy collections will be converted to "virtual library"). Nevertheless, the Library of Congress recently initiated a five-year program to digitize five million items from its collection, at a projected cost of $\$ 60$ million, or an average of $\$ 12$ per item. See Terry Pristin, Selling History, Reel to Reel, to Today's Media, N.Y. TIMES, Oct. 9, 1995, at DI.

389. See CRAWFORD \& GORMAN, supra note 21 , at 29-30 (noting cost savings from electronic distribution of up to $30 \%$ for a hardbound book, but questioning whether that represents sufficient portion of hard copy publishing and distribution costs to represent "major savings").

390. To the extent they recognize the need for copyright at all, minimalists tend to favor a short term of protection. James Boyle, for example, proposes that copyright should last for only 20 years. See BOYLE, supra note 97, at 172. On the other hand, Professor Boyle expresses support for sui generis intellectual property regimes for information products. See id. at 170-72. This might lead him to consider favorably my proposal for a short-term digital publisher's right. 
subsidize) creative exchange, it would not prevent sampling or transformative reformulations. Nor would it prevent hard copy editions of the public domain work, so long as such editions were created independently and not by downloading the protected digital version. The right's duration would roughly approximate the period that is necessary to provide a reasonable incentive for such digital "publication," probably ten years at most. Thereafter, any online provider would be free to include the work in its catalogue, and the Library of Congress, which would receive a digital deposit of the protected work, would make the work available online to the public at large.

\section{B. Personal Uses}

Copyright has traditionally been designed to protect copyright owners against competitors who illicitly appropriate a share of the owner's mass market, either by distributing infringing copies to the public or by conducting infringing public performances of the copyrighted work, whether live or over the air. Copyright has not generally required owner authorization for an individual's personal uses of protected works, whether such uses entail reading, listening, private performances, or even home copying. Such personal uses have either fallen outside the scope of copyright's exclusive rights or have generally been deemed to be a noninfringing de minimis or fair use. ${ }^{391}$ But with the advent of online dissemination of authors' works, the distinction between mass market infringement and personal use appears to be breaking down. The NII White Paper maintains, with some case law suppon, ${ }^{392}$ that even the temporary fixation of a protected work on a computer's random access memory, such as is required to view a work resident on another computer, constitutes an actionable reproduction of the work, absent authorization or fair use. ${ }^{393}$ It also contends that fair use for otherwise infringing personal uses should no longer be available, given the development of collective licensing and computerized tracking systems that greatly reduce negotiating costs. ${ }^{394}$ As a result, under the legal regime anticipated and favored by the White Paper, individuals would require a copyright license to view or listen to protected works or to give or lend a "book" to a friend via

391. The Copyright Act, 17 U.S.C. § 106 (1994), accords copyright owners with a specified bundle of exclusive rights, including the rights to reproduce the work, to prepare derivatuve works, 10 distnbute copies or phonorecords to the public, to perform the work publicly, and to display the work publicly Uses like reading a book, listening to the radio, or singing a song in the shower. that do not fall within the scope of any of these rights, are not infringements. Other uses, like hand copying portsons of a copynghted article or loudly playing a portable cassette player in the park. do run afoul of the owner's nghts but are generally deemed to constitute de minimis or fair use. See 2 NIMMER ON COPYRIGHT, supra note S6. $\$ 8.01$ (G), at 8-25.

392. See MAI Sys. Corp. v. Peak Computer. Inc. 99I F.2d 511. 519 (9th Cir. 1993) (holding that loading of computer software into RAM creates "a copy").

393. See NII WhITE PAPER, supra note 6, at 64-66.

394. See supra note 65. 
the Internet. A library that made its collection of texts available for online perusal would also likely infringe upon the owners' copyrights by virtue of Congress's extension of the exclusive right of public display to remote serial access. ${ }^{395}$

The neoclassicist approach embraces the propertization of personal uses and appears to have significantly influenced the authors of the White Paper. Neoclassicists assert that, as new collective licensing institutions and computerized tracking systems sharply reduce negotiating costs and as digital technology makes possible ever more exact price discrimination, a regime of property rules and market transactions should be the cyberspace norm. ${ }^{396}$ They argue that copyright holders should capture the social value of reading or borrowing a book online, just as broad property rights should encompass the value of physical resources. ${ }^{397}$ For neoclassicists, the extension of copyright to such private uses would enable the market pricing system to achieve efficient resource allocation more fully. It would give copyright holders the capacity "to channel their investments more precisely to meet ... newly articulated patterns of demand." 398

Minimalist critics, on the other hand, insist that the "free use zone" of the hard copy world, including such uses as reading, viewing, or listening to an authorized copy of a work, browsing in a bookstore or newsstand, lending a book or sound recording to a friend, and borrowing from a public library, must be maintained in cyberspace. ${ }^{399}$ They argue that the extension of copyright

395. See supra note 64 . Similarly, making a copyrighted film or song available for serial online viewing or listening would likely fall within the copyright owner's exclusive right of public performance. See Columbia Pictures Indus. v. Redd Home, Inc., 749 F.2d 154 (3d Cir. 1984) (holding that video store operator infringed public performance right when he rented motion picture tapes to customers and provided semi-private rooms where tapes could be viewed); On Command Video Corp. v. Columbia Pictures Indus., 777 F. Supp. 787 (N.D. Cal. 1991) (holding that hotel movie viewing system that allowed guests to view movies in their rooms by selecting tapes to be played on remote-controlled console in hotel basement infringed public performance right).

396. See, e.g., Hardy, supra note 3, manuscript at 27-35. Hardy would allow fair use only for uses that are "either trivial, or undertaken for unusually worthy purposes." Id. manuscript at 33.

397. Appiying this approach, the NII White Paper suggests that universities and libraries should have to pay full market price for expressive material, just as they must pay for tangible supplies. See NII WHITE PAPER, supra note 6, at $84 \mathrm{n} .266,88$; see also GOLDSTEIN, supra note 21, at 202 (asserting that "as new technological uses of copyrighted works emerge, lawmakers should be quick to extend copyright to encompass them, even if the uses are construed as private"); Easterbrook, supra note 8, at 110-11 (favoring like treatment of intellectual property to physical property and arguing that "quasi-rents . . . are common in every industry with specialized assets").

398. GOLDSTEIN, supra note 21 , at 200.

399. See, e.g., Elkin-Koren, supra note 40, at 273, 277 (opposing extension of copyright to digital "borrowing" and asserting that users of expression disseminated over digital networks must be allowed "10 do the same things they are able to do in a non-digitized cnvironment"); Hamilton. supra note 12, at 623 (coining the term "free use zone"); id. at 632 (summarizing application of free use zone on Global Information Infrastructure); Litman, supra note 3, at 40 (advocating user's "right to read" and suggesting that Copyright Act should be amended to clarify that "an individual's ordinary reading, viewing, or listening to an authorized copy of a work does not invade the copyright owner's rights"); see also Samuelson, supra note 3, at 137-38, 189, 191 (arguing against extension of copyright to such uses, or their digital equivalents, at least until such time, if any, that it becomes apparent that some such protection is required in digital markets). 
to the digital equivalents of such uses would disturb copyright's traditional balance and would amount to an unwarranted and unprecedented incursion into individual liberties. ${ }^{400}$ They contend that the Copyright Act should be amended, if need be, to make clear that individuals should be permitted to make and transmit copies of works online to friends or family for personal use, that public libraries should be able to afford patrons remote access to digital works in library collections so long as the patron does not keep a permanent copy of the work, and even that commercial publishers should be prohibited from charging prospective customers for electronic browsing through the publishers' digital products. ${ }^{401}$

The democratic paradigm eschews the neoclassicist principle that copyright owners should be entitled to appropriate the entire consumer surplus whenever and wherever market transactions and comprehensive price discrimination are possible. At the same time, however, the paradigm would see no reason to cling to hard copy distinctions in the digital network environment. Digital network technologies will radically alter copyright markets. ${ }^{: 02}$ Specifically, widespread digital dissemination will substantially diminish author revenues from the sale of hard copies. As this occurs, authors will become increasingly dependent on revenues from digital dissemination-and on legal mechanisms that ensure that they can receive such income. With that in mind, and in order to continue to provide a robust public subsidy for authors' autonomous creative expression, copyright will have to be extended to many digital uses. That extension would constitute a substitute for copyright owner rights that will have a far diminished utility in the digital market and not an onerous expansion of copyright's scope.

Consider, for example, library patrons' remote access to digital collections. In the hard copy universe, only one patron at a time can borrow any given book from the library. Persons who want to keep a book permanently or who need to see the book before another patron returns it must buy their own copy. With remote digital access, however, hundreds or thousands of patrons will be able to access the book at the same time. In addition, many people who might otherwise have wanted to buy their own permanent copy will now settle for being able to access the book online whenever they wish. Given technological and cultural constraints, in the near term this would likely occur much more

400. See NII Copyright Protection Act of 1995: Hearmgs on HR 24+1 Before the Subcomm on Courts and Intellectual Property of the House Comm. on the Judictan. 104th Cong (1996) (statement of Consumer Product on Technology) (maintaining that legislation implemienting White Paper recommendations would have far-reaching negatuve consequences regarding personal ponva)). Barlow. supra note 21 , at 86 (asserting that broader and more ngorous enforement of intellectusl property in cyberspace will "inevitably threaten freedom of speech").

401. See, e.g., Hamilton, supra note 12, at 631-32: see also AMERICAl ASS' OF RESEARCH LIBRARIES, STATEMENT ON LAWFUL USES OF COPYRIGHTED WORNS (1995) (assertung thal " [w]ithout infringing copyright, the public has a right to expeet . . to read. to lisien. or view publicly marketed copyrighted material privately, on site or remotely").

402. See Ginsburg, supra note 3. at 1477-78; supra note 21. 
with libraries' sound recording collections than with books, but as online access offers more of the comforts of having one's own hard copy and, possibly, as new generations of readers become less desirous of the "feel" of a hard copy, it will happen with increasing frequency with books and other written material as well. ${ }^{403}$

Authors and their publishers will have two basic possibilities for making up the resulting loss in hard copy sales. They could exact from libraries a large up-front payment in an amount calculated to cover the expected loss in revenue or they could charge a much smaller amount for each remote access use. ${ }^{404}$ While minimalist critics seem to assume that such per use charges would be levied against library patrons, thus undermining libraries' traditional role in providing patrons with free access to their collections, there is no reason that libraries (or other public institutions) could not assume all or part of such charges for needy patrons. Moreover, per use charges have a certain advantage over up-front fees in that they could provide at least a rough indication of the kind of works that library patrons wish to access, enabling libraries to tailor their purchasing decisions and authors to tailor their creating decisions accordingly. ${ }^{405}$ Either way, libraries or remote access patrons will have to make up the loss in author revenue resulting from digital remote access. Otherwise, as authors cut back on production or rely more heavily on state or private patronage, libraries will have far fewer and far less diverse "sustained works of authorship. ${ }^{406}$

A similar analysis would apply to online "browsing," the calling up of all or a portion of a work on the network user's computer screen without

403. See Volokh, supra note 21 , at 1823-25. But see CRAWFORD \& GoRMAN, supra note 21, at 17-22 (doubting whether computer and display technology will ever equal advantages of reading books and lengthy texts on printed page).

404. The up-front payment could take one or more of several types of fees. It might be: (1) a license fee for permitting a library to make digital reproductions of certain hard copy works in its collection; (2) a license fee for downloading and storing in the library's computer permanent copies of new works that are created in digital format; or (3) a blanket license fee for unlimited digital display of the works to the library's remote access patrons. To some extent, publishers already engage in similar price discrimination, charging libraries and other institutional subscribers of certain journals a significantly higher subscription fee than that charged to individual subscribers. See American Geophysical Union v. Texaco, Inc., 60 F.3d 913, 936 (2d Cir. 1994) (Jacobs, J., dissenting) (noting that plaintiff journal publisher charged institutional subscribers double normal subscription rate in expectation that employees would copy articles for personal use). At the same time, newspaper and journal publishers often charge teachers and students a lower rate than other users.

405. Much the same benefit could be achieved by calculating the library's blanket license fee in accordance with a system that yields statistical samples of patron uses, such as that in employed by ASCAP, the Copyright Clearance Center, and other collective licensing organizations. See DAvID SINACORE-GUINN, COLLECTIVE ADMINISTRATION OF COPYRIGHTS AND NEIGHBORING RIGHTS: INTERNATIONAL PRACTICES, PROCEDURES, AND ORGANIZATIONS 383-91 (1993) (discussing various forms of collective blanket licensing). Given bounded rationality distortions, patron per use charges would yicld only imperfect information about audience receptivity to author's works and, partly as a result, should not serve as a basis for expanding copyright's scope. See supra text accompanying note 241 . But everything else being equal, given a choice between a flat fee that takes no account of patron interest and a charge per use system that does, the latter might be preferable.

406. See supra text accompanying note 272. 
downloading a copy to disk. Such activity should not fall within the ambit of copyright owner prerogatives simply because it has social value or because, given current technology, it might be construed to involve the making of a "copy" of the browsed work in the computer's random access memory. ${ }^{+07}$ But neither should it be exempted from copyright merely because it can be analogized to "reading" a book or newspaper. The extension of copyright over online browsing, or for that matter, personal downloading, should instead depend on a measured assessment of the extent to which such activities, if permitted on a mass scale, would erode existing copyright markets. In making such a determination, moreover, it must be kept in mind that audience payments do not merely provide an incentive for the creation and dissemination of original expression. They must also be sufficient to subsidize a vital and independent sector of expressive activity. To be certain, charges for such digital uses would represent an audience "tax," no less than whatever incremental amount copyright adds to the price of books or newspapers. ${ }^{\text {sus }}$ But such a tax, paid in some form and for some use or another, is a necessary source of funding for a central component of our system of free expression.

At the same time, the democratic paradigm would not support author and publisher appropriation of a greater portion of the consumer surplus than is necessary to support self-reliant and diverse authorship. To that end it would view with considerable skepticism the neoclassicist embrace of collective licensing as a panacea for overcoming transaction cost barriers to privale use licenses. ${ }^{409}$ Collective licensing organizations, like ASCAP and the Copyright Clearance Center, typically enforce the copyrights of their members by granting users a blanket license to use the works in the organization's catalogue. ${ }^{410}$ In so doing, they enable authors to receive payment from widely dispersed users, many of whom might otherwise infringe with impunity, and they provide users with the opportunity to deal with a single licensor for a broad panoply of works. Neoclassicists extol such organizations as evidence of the market's ability to generate private solutions to transaction cost barriers.

407. The White Paper would extend copynght over online browsing for bolh reasuns See supra nute 66. For a further, cogent critique of this formalist approach, see Litman, stupra note 353, at 37

408. In assessing the financial burden that such charges might impase on users. however, one must take into account the vastly reduced price for digital, as opposed to hard copy. distribution. and the suvings in time and money in being able to view a work from home rather than hasing to go to a bookstore. library, or newsstand. See Volokh. supra note 21. at 1809. 1825 (discussing incipensise electionic distribution of music and text). Moreover, charges for such digital uses might be considerably less intrusise and onerous than some minimalist critics fear. Charges could take place automatucally and mechanically. much like toll charges on a phone bill or, more likely, as a lump sum heense fec, added to the user's monthly Internet access provider bill, that would cover all instances of browsing or dounloading

409. See, e.g., GoldSTEIN, supra note 21. at 218-23 (discussing ASCAP and Copynghi Clearance Center); Merges, supra note 168; Merges, supra note 164, at 2669-70 (maintainung that "the history of collective rights organizations such as ASCAP supports the main theoretical point that a properny rule for [intellectual property rights] can be transformed into a voluntary lability rule. in the form of an effective institution to carry out [intellectual property nghts] transactions")

410. See SinACORE-GUIN, supra note 405, al 383-90. 
thus obviating the need for statutory compulsory licenses, fair use, and other limitations on proprietary copyright. ${ }^{41}$ However, they forget that collective licensing organizations are plagued by problems of monopoly power and pricing. ${ }^{412}$ For that reason, both in the United States and in other countries, such organizations are typically subject to considerable state-enforced constraints on the license fees they may exact and the extent of the rights they may represent. ${ }^{43}$ To the extent that private use licenses, including those for library remote access, are administered by collective licensing organizations, the democratic paradigm would accordingly prescribe a system of state regulation to ensure that user license fees remain within reasonable limits. ${ }^{4 / 4}$

\section{Transformative Uses}

Digitization makes possible the infinite manipulability of existing works, opening up a myriad of possibilities for transformative uses. These may range

411. Robert Merges's recent paean to collective licensing takes this neoclassicist embrace to new heights. Merges lauds collective licensing organizations as paradigmatic institutions of private ordering. remarkably shunting to the side the extensive government regulation of such organizations in both the United States and abroad. Compare Merges, supra note 168, manuscript at 45 ("antitrust enforcement . . . has appeared to constrain [ASCAP] somewhat"), with Stanley M. Besen et al., An Economic Analysis of Copyright Collectives, 78 VA. L. REV. 383, 387-88, 395 (1992) (stating that "collectives [such as ASCAP] have been subject to detailed regulation" governing types of licenses that collectives may offer and administer, levels and distribution of license fees, collective membership restrictions, collective obligations to nonmembers, and appropriate damages for infringement). In particular, Merges concludes, relying on the relative infrequency of fee-setting litigation, that ASCAP fees continue to be "established by negotiation," just as "in the past," before its 1950 antitrust consent decree. See Merges, supra note 168, manuscript at 46. Here Merges neglects the "New Institutionalism" literature (on which he otherwise heavily relies) showing that economic agents will often transact against the backdrop of state entitlements and institutions without actually resorting to them. See id. at 23-26 (canvassing New Institutionalism literature). It secms highly likely that users' automatic right to an ASCAP license upon application, coupled with their right to petition the court for determination of a "reasonable fee" in the absence of agreement and the underlying threat of private antitrust action, heavily color ASCAP license negotiations, even if few users have actually filed a petition for judicial determination of fees. See infra note 413.

412. Collective licensing organizations pool the copyrights of their members, thus enhancing their power in negotiating with users. ASCAP and BMI operate pursuant to the terms of consent decrees issued in connection with an antitrust action brought by the Department of Justice. See Broadcast Music, Inc. v. CBS, Inc., 441 U.S. 1, 10-12 (1979) (describing ASCAP and BMI consent decrees). They have also bcen the subject of numerous private antitnst actions. See generally Simon H. Rifkind, Music Copyrights and Antitrust: A Turbulent Courtship, 4 CARDOZO ARTS \& ENT. L.J. 1 (1985) (discussing antitrust challenges to ASCAP to illustrate evolving relationship between copyright and antitrust laws).

413. See SINACORE-GUINN, supra note 405, at 604-07. Under its Consent Decree, ASCAP may not institute or commence sujt against motion picture exhibitors and may license synchronization rights and motion picture theater performing rights only in limited circumstances. See United States V. ASCAP, 1950-1 Trade Cas. (CCH) I 62,595, at 63,752-53 (\$\$ IV(F)(1), V(C)(1)-(5)) (S.D.N.Y. 1950) (Amended Final Judgment). In addition, any user automatically acquires an ASCAP license merely by applying to ASCAP for the license. See $i d$. at 63,753 (\$ IV). If the user is unable to negotiate a license fec, it may petition a judge of the Southem District of New York to fix a "reasonable fee." See id. at 63,754 ( $\$$ IX(A)). In any such proceeding ASCAP bears the burden of establishing the reasonableness of its proposed fec. See id. at $63,754(\S \mathrm{IX}(\mathrm{A}))$.

414. State regulation would not be needed if each author or publisher were free to negotiate his or her own user charges since this practice would not pose the problem of monopoly power that is endemic to collective licensing. The Copyright Office has begun a project to allow such individualized licensing online. See supra note 384. 
from modifications and adaptations of a single work to multimedia works that incorporate an array of discrete components from numerous existing works. ${ }^{415}$ They may include transformative works that bear only a scant resemblance to the existing work as well as those in which the existing work or works are easily recognizable.

As discussed in Part I, through most of the nineteenth century authors were free to transform existing works so long as they made a substantial independent contribution. But today, transformative uses that are deemed to appropriate the original work's expression, and not just its idea, fall within the exclusive control of the holder of the copyright in the original work, unless excused as fair use. Copyright now includes an exclusive right to make derivative works. Moreover, the reproduction right has expanded dramatically. In addition to substantial literal or near literal copying, it now encompasses nonliteral "total concept and feel" similarity and literal copying of small fragments of the original work. In effect, copyright's reproduction right now provides an implicit derivative right largely coterminous with the explicit one. ${ }^{416}$

The neoclassicist approach would give the owner of an existing work the exclusive right to authorize any such transformative uses. Neoclassicists recognize that a copyright owner's exclusive right to make derivative works may well go beyond what is necessary to provide an incentive for the creation and dissemination of the original work. ${ }^{47}$ They argue, however, that the derivative right serves to direct investment towards those works that are capable of being developed in ways that consumers want, including, for example, books that are well suited to screen adaptation or motion pictures and television programs with characters that can readily be spun off into product merchandising. ${ }^{418}$

415. So-called "multimedia" works are works that combune text, mustc. stıll inages. graphics, and tull. motion video in digital format. See Jennifer D. Choe. Interacme Mhummedia: A Nen Technologv Tests the Limits of Copyright, 46 RUTGERS L. REv. 929. 931 (1994) As the NII White Paper points out, the term "multimedia" is a misnomer; such creations actually involve the fixation of worhs of sanous categones in a single medium. See NII WHITE PAPER, supra note 6. al 41-42 However, since "mulumedia" is ihe term that is commonly used, I will use it here as well.

416. See supra text accompanying notes 71-76. Even a broad reproduction nght is not enturely coterminous with the derivative right. The reproduction nght ma) only be infonged by an unauthonzed fixation in copies or phonorecords, whereas the denvaluse nght may be infonged by a nontixed performance. See H.R. REP. NO. 94-1476, al 62 (1976), reprinied in 1976 U S C C A N 5659. 5665 Nimmer asserts, however, that the denvatuve nght is "completely superfluous" since any infringement of that right would also infringe the reproduction nght or the performance nght See 2 Niststes ov COPYRIGHT, supra note 56. $\$ 8.09[\mathrm{~A}]$. at $8-123$. Professor Goldsteın has cogently argued that in order to be a derivative work, as opposed to merely a substantally similar reproduction. the word should involve a "contribution of independent expression to an exisung work [that] effecturely creates a new work for a different market." GoLDSTEIN, supra note 18. $\$ 5.3 .1$, at 5.82

417. See supra note 144.

418. See supra note 145. 
Some copyright expansion critics, on the other hand, have suggested that the derivative right should be effectively eliminated. ${ }^{419}$ If this were the case, secondary authors would be free to create adaptations and translations of existing works, as was generally the case until the late nineteenth century. Other critics have proposed that the derivative right should be subject to a compulsory license. ${ }^{420}$ In that event, secondary authors would be entitled to produce and disseminate transformative works without owner authorization upon payment of a statutory license fee or judicial damage award.

The democratic paradigm would reject both the neoclassicist and minimalist positions. It would advocate varied treatment for different types of transformative uses in an effort to maintain author incentives without unduly suppressing secondary borrowing. From the democratic perspective, a broad derivative right poses an unacceptable burden on expressive diversity. Given copyright owners' propensity to private censorship and systematic ability to demand supracompetitive license fees, copyright owners' expansive control over transformative uses unduly stifles the creative reformulation of existing expression, serving in the process to bolster cultural and market-based hierarchy. ${ }^{421}$ The neoclassicists' claim that the pricing system will induce owners to invest in the development of a full range of expression is too uncertain to outweigh such a burden. ${ }^{422}$ Seen in that light, it would be preferable to allow free competition and a diversity of expression among secondary authors in the adaptation of existing works and their components.

On the other hand, in many instances the elimination of the exclusive derivative right would undermine the incentive that copyright provides for the creation of the original work. This problem would be particularly acute whenever an adaptation maintains the essential content of the original work in the same or another form. If the holder of the copyright in a book did not have the exclusive right to authorize translations, for example, the book could freely be translated into a foreign language and then back into the original language,

419. See, e.g., Jaszi, supra note 9, at 304-05 (denouncing derivative right and total-concept-and-fecl test for reproduction right infringement as outmoded vestiges of Romantic view of authorship); Lunney, supra note 30, at 650 (maintaining that derivative right should be limited to "those instances where an individual has exactly or near exactly reproduced a copyrighted work in a new language or medium of distribution"); Sterk, supra note 30, at 1217 (concluding that derivative right is "generally inconsistent with the incentive justification for copyright" and doubting whether its abolition would "increase overall litigation rather than just shift boundary lines").

420. See Hamilton, supra note 97, at 120-22 (1994) (citing sources).

421. See supra notes $33-42$ and accompanying text.

422. See supra notes $241-46$ and accompanying text. In addition, although copyright's democratic paradigm admittedly does not generally distinguish between works of political speech and works of entertainment, a rule that encourages studios to produce and invest in those films and television programs that can best be used to sell coffee mugs, T-shirts, keychains, and other consumer items bearing character likenesses hardly serves the objective of robust democratic discourse. See GrEGORY J. BATTERSBY \& Charles W. Grimes, The LaW of Merchandise AND Character Licensing, $\$ 2.03[1]$, at 2-9 to 2-12 (1995) (describing how desire to maximize potential for product merchandising and promotional tie-ins drive motion picture company decisions regarding film selection, characters, images, plot, and implements used in film). 
competing directly with the book in its primary market. ${ }^{423}$ Likewise, works that are quite similar to the original, including edited films and television programs, are sometimes viewed as derivative works of their unedited versions, ${ }^{424}$ and these could act as market substitutes for the unedited versions.

In addition, a derivative right is sometimes necessary to avoid "multiple taker" problems. ${ }^{425}$ Without the ability to exclude multiple transformative users, it is highly unlikely that anyone would create derivative works that take a number of months or years to produce and require a significant capital investment. An example would be the production of a motion picture based on a popular novel. Few studios would invest the tens of millions of dollars that is generally required to produce a commercial full-length feature film without the right to prevent would-be competitors from releasing a film based on the same novel. ${ }^{426}$ To the extent that such capital and time intensive derivative works contribute to our public discourse (and not because of the neoclassicist direction of investment rationale), we may wish to accord an exclusive derivative right, so long as it would not unduly burden noncompetitive transformative uses.

In contrast, there are other instances in which limitations on owner ability to prevent transformative uses would appear to support expressive diversity without undermining copyright incentives. A case in point involves so-called "cover recordings" of songs that have previously been recorded and distributed to the public. ${ }^{427}$ Section 115 of the Copyright Act provides for a compulsory license for cover recordings, enabling performers to make their own renditions of previous recordings upon payment of a statutory fee to the holder of the copyright in the original musical work. ${ }^{428}$ Unlike motion picture adaptations,

423. The same would be true of two-dimenstonal drawings of three-dimensional seulptures, dolls and toys, and vice versa. For that reason the holder of a copynght in a three-dimensional graphic uork may prevent an unauthorized two-dimensional representation of the work, and the holder of a copynght in a twodimensional drawing may prevent an unauthorized three-dimensional representation of the irawing See. e.g., Fleischer Studios, Inc. v. Ralph A. Fruendlich, Inc., 73 F.2d 276. 278 (2d Cir 1934). Kıng Features Syndicate v. Fleischer, 299 F. 533, 535 (2d Cir. 1924). This rule does not apply uth regard to unitanan aspects of a three-dimensional useful article. whether embodied in the article or depicted in a ino-

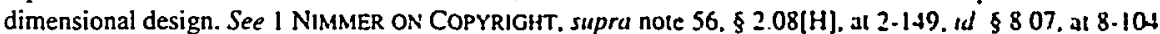

424. See, e.g., WGN Continental Broad. Co. v. United Video. Inc , 693 F 2d 622. 625 (7th Cir 1982) (holding work that deleted parts of new program constututed infringing denvatue uork). Gillam y $A B C$. 538 F.2d 14, 21 (2d Cir. 1976) (holding that unauthonzed ediung of work. if proven, would constutute infringing derivative work, going beyond scope of license to make copies of uork)

425. A multiple taker problem exists when an owner who lacks the nght to exclude will not pay a prospective taker to prevent a taking because the owner would subsequently have to pay another prospective taker not to take, and then another and another. See Kaplow \& Shavell. Propern Rules, supra note 247 , at $765-66$ (identifying multiple taker problem as limitation of liability rule regimes in some circumstances).

426. See Bermard Weinraub, Two Films. One Subject. Uh.Oh In Hollswood. the Race is On, XY TIMES, June 23, 1994, at CII (reporting as highly unusual contemporaneous development by two major studios of motion pictures based on same story about threatened escape of deadly vinus from medical lab)

427. See AL KOHN \& BOB KOHN, KOHN ON MUSIC LICENSING 656-60 (2d ed 1996)

428. The compulsory license is available only when a recording of the song has been previously 
cover recording artists do not appear to be particularly deterred by the possibility of multiple transformative uses. ${ }^{429}$ In fact, many popular songs are the subject of numerous cover recordings. ${ }^{430}$ Nor does the section 115 compulsory license appear to have unduly dampened incentives to create and record original musical works. Indeed, in many instances the holders of musical work copyrights grant permission to produce a cover recording at less than the statutory rate. ${ }^{43 !}$

Much digital manipulation would appear to impose no greater burden on copyright incentives than does the cover recording compulsory license. A prime example is digital sampling. Digital sampling involves the use of computer technology to copy short segments from existing recordings, texts, or motion pictures for inclusion in transformative sound recording or multimedia works. ${ }^{432}$ So long as the sampled material does not constitute the signature theme of the original work and so long as the sampler has made her own significant creative contribution to the secondary work, such transformative uses are generally free from multiple taker and market substitution problems (unless one broadly defines the relevant market, in neoclassicist fashion, to include any possible transformative use). ${ }^{433}$

distributed in the United States with the copyright owner's permission. See 17 U.S.C. $\$ 115(\mathfrak{a})(2)(1994)$. Section 115 also requires that notice be given to the copyright owner and that the cover artist refrain from changing the "basic melody or fundamental character of the work." $/ d$. The statutory fee is dependent on when the original phonorecord was produced and currently varies from 4.0 cents to 6.6 cents per song per copy, or .75 cents to 1.25 cents per minute of playing time, rounded up to the next minute, whichever is larger. See 37 C.F.R. $\$ 255$ (1995).

429. A cover recording does not constiture an independently copyrightable derivative work, "except with the express consent of the copyright owner." 17 U.S.C. $\$ 115(\mathrm{a})(2)$.

430. As of November 1995, for example, the Beatles songs "Yesterday" and "Eleanor Rigby" had becn the subject of 72 and 51 cover recordings, respectively. See Beatles Still Under Cover: A Look at Statistics That Shape Our Lives, USA TODAY, Nov. 22, 1995, available in 1995 WL 12679375.

431. Telephone Interview with Charles Sanders, In-House Counsel for the Harry Fox Agency (Nov. $16,1995)$. The agency acts as the agent for a large number of musical work copyright owners in granting cover recording and other mechanical recording licenses. According to $\mathrm{Mr}$. Sanders, only about $40 \%$ to $50 \%$ of the approximately 150,000 cover recording licenses that the Agency issues each year are at the statutory rate, and this figure does not include the many below rate in-house licensing transactions between record companies and their affiliates. The primary reason for the issuance of cover licenses below the statufory rate, he explains, is that recording contracts typically include a control composition clause, which requires the songwriter/artist to provide the record company with a rate on that person's songs that is threequarters of the statutory rate. Other typical instances of below statutory rate licenses include packaged recordings of older artists and record club releases. See KOHN \& KOHN, supra note 427, at 659-60.

432. See David Sanjek, "Don't Have to DJ No More": Sampling and the "Autonomous" Creator, 10 CARDOzo ARTS \& ENT. L.J. 607, 612 (1992) (describing use of Musical Instrument Digital Interface synthesizers, which take audio signals and convert them into string of computer digits that can be held in random access memory, retrieved, scrambled, and introduced into given recording).

433. This would not be so where the entire original work is only a couple of phrases or sounds, as in the case of the short, original samples that are created for compilation in sound recordings, known as "samplers," which are sold to musicians who wish to incorporate samples in their own works. See Anita M. Samuels, Freeze-Dried Music: Just Add Artists, N.Y. TIMES, Sept. 4, 1995, at A2 (reporting increasingly widespread use of samplers). In this case, however, while the entire sampler would generally be protected as a compilation against the literal or near-literal copying of its selection and arrangement of samples, it is questionable whether the individual samples, each taken separately, would be sufficiently original to qualify for copyright protection. See I NIMMER ON COPYRIGHT, supra note 56, $\$ 2.01$ [B], at 2-17 to 2-18 (stating that short phrases do not generally qualify for copyright protection unless they exhibit sufficient 
Accordingly, depending on the quantitative and qualitative importance of the sampled material for the original work and the nature and extent of the sampler's own contribution, such transformative uses should either qualify as a fair use, with the burden on the plaintiff to show market substitution, or be subject to some form of compulsory license. ${ }^{43+}$

Such a regime would generally maintain copyright owner remuneration for transformative uses of more than immaterial isolated components of the original work, but would do so through liability rules, rather than neoclassical property rules. It would thereby promote multifarious digital uses of existing components without impairing copyright incentives. Prevailing uncertainties regarding whether sampling constitutes infringement and the significant costs involved in seeking and obtaining permission to use sampled material have often made the use of existing content in multimedia works prohibitively expensive, thus obstructing the development of this new form of expression. ${ }^{435}$ This problem has been exacerbated by the reluctance, under today's property rule regime, of many content owners to issue blanket licenses for transformative uses of their works and by the tendency of many of those who are willing to license to insist on full per copy royalties even when the multimedia work incorporates only a small excerpt of the licensed work. ${ }^{46}$

In such a case, contrary to the neoclassicist view of compulsory licenses as obstacles to the formation of market solutions to licensing barriers, ${ }^{437}$ certain liability rule regimes might actually be more conducive to overcoming those barriers than a property regime. ${ }^{438} \mathrm{By}$ imposing a liability rule, the democratic paradigm would in effect force content owners to bargain under the shadow of a compulsory license, thus leading to the development of private collective licensing institutions for multimedia uses of existing content. ${ }^{49}$ In

creativity). But see Tin Pan Apple Inc. v. Miller Brewing Co. 30 U S.PQ.2d (BNA) 1791 (S D X Y 1994) (declining to hold, as matter of law, that defendant's digital sampling of uords "Hugga-Hugga" and "BrT" from plaintiff's song constituted noninfnnging copyung of noncopyrightable malerusl)

434. Among the possible types of compulsory licenses are state determined across-the-board tees. individualized judicial damage awards, and voluntary negotistions under the shadow of binding arbutration in the event of negotiation failure. For a bnef discussion of these alternatives and their possible ramifications for efficient bargaining, see supra note 248.

435. See OFFICE OF TEChNOLOGY ASSESSMENT, 102D CONG. FINDING a BAlANCE COMPLTER

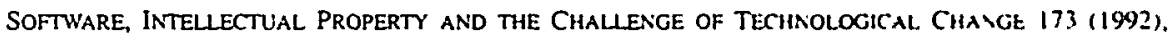
Choe, supra note 415, at 948-49. There are two pnncipal sources of legal uncertannly regarding the use of sampled material. First, it is unclear whether any given instance of digual simpling constitutes 4 noninfringing de minimis or fair use. See supra note 75 . Second. given that much content was created and licensed prior to the advent of multimedia technology. It is often unclear whether licensees have the night to sublicense multimedia uses. See Jane C. Ginsburg. Domestic and Intemutional Copiright issues Implicated in the Compilation of a Multimedia Product. 25 SETON HALL L REV 1397. 1409-11 (1995)

436. See Kevin J. Harrang. Licensing Issues in Creanng and Publisinng M/ultumedtu Sofnuare Products.

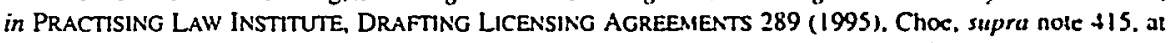
$948-49,980-82$ (noting absence of collective licensing institutions designed specificali, for multumedia uses as obstacle to multimedia development).

437. See, e.g., Krier \& Schwab, supra note 123, at 464: Micrges, supra nole 164. at 2662-64

438. See supra notes $247-48$ and accompanying text.

439. See supra note 248 . 
contrast to licensing under a property rule regime, a content owner could not extract the prospective user's surplus as a bribe for agreeing to license the work. ${ }^{440}$ But the liability ceiling could be set so that owners would generally receive sufficient compensation to maintain a robust incentive for the creation of original works. ${ }^{441}$ Given the vital importance of transformative uses for diversity of expression, ${ }^{442}$ even if one views such a regime as a partial transfer of wealth from authors of existing content to transformative authors, this transfer is fully warranted by copyright's democracy-enhancing objectives. $^{443}$

\section{Displacement of Copyright by Contract}

Placing substantial amounts of original expression in electronic databases, together with technological means of preventing unauthorized user access, copying, and manipulation, will accord online content providers with the farreaching ability to obtain, through the laws of property and contract, the sort of broad, monolithic control over such expression that copyright doctrines such as fair use, the idea/expression dichotomy, and limited duration might otherwise preclude. ${ }^{444}$ The neoclassicist approach regards positively or with equanimity such contractual expansion of copyright owner rights. Neoclassicists' legal marginalism and tendency to view social policy through the lens of bilateral market transactions leads them to elevate contractual arrangements over the fundamental democratic interest in maintaining a vibrant

440. See Kaplow \& Shavell, Property Rules, supra note 247, at 771 (noting that "[u]nder property rule protection, when owners sell things, they tend to receive more than the value they place on them; they are generally able to extract some of the buyers' surplus," whereas under "the liability rule, owners' valuation is all that they are in principle awarded").

441. Commentators generally agree that whatever may be their benefits for efficient resource allocation, liability rules have a socially inefficient tendency to reduce owners' ex ante incentives to invest in productive activity and development conceming the asset that is subject to the rule. See, e.g., Ayres \& Talley, Solomonic Bargaining, supra note 247, at 1083; Kaplow \& Shavell, Property Rules, supra note 247. at 722 . In the case of sampling, however, the transformative use would act as a market substitute ncither for the original work nor for traditional adaptations, such as translations, motion picture versions, or dramatizations. A liability rule for sampling would thus not be expected to dampen owner incentives with regard to the creation and development of these works. A liability rule for sampling would, in theory, dampen owner incentives to invest in works that can easily be broken down into easily sampled components, but since, with digital technology, all works can be easily broken down in that manner, that theoretical incentive distortion would have little real consequence.

442. See Campbell v. Acuff-Rose Music, Inc., I14 S. Ct. 1164, 1171 (1994) (emphasizing that "the creation of transformative works" serves copyright's fundamental objectives and thus lies at "the heart of the fair use doctrine's guarantee of breathing space").

443. Neoclassicists sometimes argue that income tax and direct subsidies are superior to legal rules as a means of meeting distributional goals. See, e.g., GOLDSTEIN, supra note 21, at 225 (raising possibility of direct cash subsidies to users as altemative to limiting copyright holder entitlements); Kaplow \& Shavell, Property Rules, supra note 247, at 771 . However, govemment subsidies for transformative uses of protected expression would have the same deleterious effect on author autonomy as would government subsidies for the creators of such protected expression. Even if the neoclassicist preference for income tax and direct subsidy holds in other areas, it makes no sense in this area of copyright.

444. See supra text accompanying notes 87-93. 
public domain. ${ }^{445}$ Indeed, neoclassicists effectively treat copyright itself as if it were the result of buyers' and sellers' undertakings, which the government simply enforces. ${ }^{466}$ As Judge Frank Easterbrook, a leading exponent of neoclassical law and economics, puts it: "A federal law of intellectual property may promote enforcement while duplicating the terms that would (presumptively) be set by contract. If Congress misunderstands the optimal terms, any of the entitlements pre-set in the law may be eliminated by contract. ${ }^{, 447}$

In a recent opinion authored for the Seventh Circuit in ProCD Inc. v. Zeidenberg, ${ }^{448}$ a case upholding the enforceability of shrinkwrap licenses, Judge Easterbrook made clear that, in his view, copyright limitations, no less than entitlements, are freely abrogable by market actors. ${ }^{* 9}$ Coupled with the White Paper's support for the displacement of copyright by online licensing, Judge Easterbrook's opinion represents a significant and ominous incursion of the neoclassicist approach into the digital arena. ${ }^{40}$ In ProCD, the plaintiff sought, through its shrinkwrap license, to obtain copyright-like protection for an electronic database that, following the Supreme Court's ruling in Feist Publications, Inc. v. Rural Telephone Service Co., ${ }^{\text {st }}$ lay in the public domain and could not be copyrighted. Judge Easterbrook neatly dispensed with the argument that state enforcement of such a contract should be preempted under section 301(a) of the Copyright Act. ${ }^{452} \mathrm{He}$ insisted that federal law should not generally preempt state enforcement of contractual terms and conditions since such "private ordering" is "essential to the efficient functioning of

445. See supra text accompanying notes 179-81.

446. See, e.g., Easterbrook, supra note 8, at 113-14; cf. Palmer, supra note 353, at 280 (asserting that intellectual property rights "are creatures of the state" and not, as neoclassictsts clam. "the product of an evolutionary process of interaction among interested parties that is later rattied through legal sanctions")

447. Easterbrook, supra note 8, at 114.

448. 86 F.3d 1447 (7th Cir. 1996).

449. Id. at $1454-55$.

450. For a discussion of the White Paper's support for shnnkwrap licensing and online licensing. sce supra text accompanying notes 88-93.

451. 499 U.S. 340 (1991). In Feist, the Court held that complations that lach even a modteum of creativity in their selection or arrangement are, as a matter of constitutional mandate. incligtble for copyright protection. See id. at 363-64.

452. Section 301(a) of the Copyright Act preempts any

legal or equitable rights [under state law] that are equivilent to any of the exclusise nghts within the general scope of copyright as specified by section 106 in works of authorstup that are fixed in a tangible medium of expression and come within the subject maller of copynght as specified by sections 102 and 103 .

17 U.S.C. \& 301(a) (1976). The ProCD Cour agreed that the plannuff"s database met the "subjeet maller of copyright" requirement even though, under Fetst, unonginal databases are not protected by copynght See ProCD, 86 F.3d at 1453. It held, however, that state enforement of the shnnkurap license did not meet the equivalent right requirement and thus that section 301 preemption did not apply. See id at 1455 Judge Easterbrook simply ignored another possible, Independent ground for federal preemplion. the Supremacy Clause of the U.S. Constitution, which has been held to preempt state law that contravenes federal intent to place certain types of creations in the public domasn. See Bonto Boats. Inc S Thunder Craft Boats, Inc., 489 U.S. 141, 162 (1989) (striking down Flonda patent statute as disrupure to natuonal uniformity mandated by Patent and Copyright Clause of Constututuon). 
markets. ${ }^{.453}$ At the same time, he argued that shrinkwrap licenses are merely "private transactions" that "affect only their parties." 454 Given this microcharacterization, he blithely eluded the argument that standardized contracts that systematically proscribe user copying of public domain material may frustrate the social policy behind copyright law's delicate balance of incentive and access. ${ }^{455}$ As Judge Easterbrook enunciated the Court's holding, "a simple two-party contract" does not meet the section 301(a) preemption requirement that it be the "equivalent to any of the exclusive rights within the general scope of copyright' and therefore may be enforced." 456

Minimalist critics are resolutely opposed to the expansion of copyright owner control. But in attacking copyright, some arrive at a legal marginalist position that is remarkably similar to that of the neoclassicists. In so doing, they exhibit a naive faith in user ability to sidestep copyright owner control without state intervention. ${ }^{457}$ Digital content providers enjoy an unprecedented capacity, through a combination of contract, digital encryption, and electronic monitoring, to prevent unauthorized access to and uses of expression and information stored in computer databases. Minimalists underestimate this capacity when they argue that "the best place to look for the appropriate compromise between compensation to owners and accessibility for the public is the marketplace rather than formal regulatory structures." 458

453. ProCD, 86 F.3d at 1455 .

454. Id. at 1454 .

455. Judge Easterbrook also argued that contractual limitations on copyright user rights are commonplace and elicited a number of inapt examples in purported support of that contention. These include trade secrets contracts (which are truly customized, bilateral transactions), home video rental contracts (because copyright does not extend to video rentals, these contracts are based on the video store's property right in the tape), and contracts for the provision of data searching services (which concern the provision of personal services, not copyright). See $i d$.

456. Id. at 1455 (citation omitted).

457. On the other hand, the notion that state institutions will necessarily intervene in the broad public interest is no less naive. Congress has exhibited a marked tendency to delegate the policy choices regarding copyright policy to industries that have a direct stake in proposed legislation. See generally Jessica Litman, Copyright Legislation and Technological Change, 68 OR. L. REV. 275 (1989); Thomas P. Olson, The Iron Law of Consensus: Congressional Responses 10 Proposed Copyright Reforms Since the 1909 Act, $36 \mathrm{~J}$. COPYRIGHT SOC'Y 109 (1989). The proper response to that tendency, however, is not public choice nihilism, but a renewed effort to bring the public interest to bear in legislative and administrative decisionmaking. See, e.g., Litman, supra note 3, at 53-54 (insisting that Copyright Office act more decisively and aggressively to represent public before Congress); see also RADIN, supra note 23, at 214-23 (presenting cogent critique, from Deweyan perspective, of public choice theory's reductive description of democracy as marketplace of self-interested profit maximizers). A prime example of such effort has been the work of the Digital Future Coalition, composed of 27 organizations representing creators, consumers, and distributors of information and formed in the fall of 1995 "to work towards a thorough, broad and balanced Congressional debate of U.S. copyright law and policy." See What is the DFC?, DIGITAL FUTURE COALITION HOME PAGE (visited Oct. 12, 1996) <http://www.ari.net/dfc/dfc/dfcdesc.htm>.

458. Zimmerman, supra note 3, at 411-12; see also Barlow, supra note 21, at 128 (calling for content protection based on encryption rather than intellectual property law); Palmer, supra note 353, at 284-99 (arguing, on libertarian and market efficiency grounds, that private ordering through technological fences, product bundling, and contractual arrangements are superior to state-defined intellectual property rights). But see Litman, supra note 353, at 45 (noting that, assuming availability of technological controls and adhesion contracts, "[e]ven if the copyright grant is narrowed in scope, the public will need some of its rights made explicit"). 
The democratic paradigm, on the other hand, would affirmatively disallow attempts to use standard contracts to expand copyright owner or content provider control over works that are made available to the public. In contrast to neoclassicist (and minimalist) legal marginalism, the democratic paradigm emphasizes that copyright represents a careful balance of owner right and user access designed to serve the public's paramount interest in self-reliant authorship and democratic discourse. Truly bilateral agreements, such as those providing for the nondisclosure of confidential information or prohibiting the copying of custom prepared material, do not generally implicate this public interest. But content provider attempts to circumvent copyright limitations while disseminating expressive works to the public would run afoul of the fundamental public policy underlying the Copyright Act and the Copyright Clause of the Constitution, even if knowingly and willingly agreed to by users. That public policy, so vital to our democratic institutions, cannot be subordinated to market vicissitudes and the vagaries of private contract. ${ }^{49}$ Under the democratic paradigm, therefore, such "private legislation" would be preempted. ${ }^{460}$

\section{CONCLUSION}

Copyright, James Madison wrote in the Federalist Papers, is an instance in which the "public good fully coincides... with the claims of

459. I do not mean to imply here that Congress should be unable, under the Commerce Clause, to accord protection against unauthorized uses of unoriginal compilations of data and other works that are ineligible for copyright. In so doing, however, Congress should, as with copynght, seck to obtarn a balance between incentive and access that best serves the public interest in expressive diversity and the diffusion of information.

460. The term "private legislation" was coined by Friednch Kessler to connote contracts of adhesion that were standard throughout an industry, thus representing the danger of pnvate concentration of power See generally Friedrich Kessler, Coniracts of Adhesion-Some Thoughts Abous Freedom of Contract. $\$ 3$ COLUM. L. REV. 629 (1943). Neoclassicist Robert Merges concurs that such pnvale legislation thal effects the "wholesale subversion of an imporant federal policy" should be preempted. no less than would state legislation with the same effect. See Merges, supra note 22, at 1613 But Merges would be considerably more solicitous of contractual prerogatives than would the democralic pardigm as I have crafted it. He would impose a caveat on preemption, limiting preemption to a nebulous category of carcumstances in which the offending licensing provision has become "rotally pervasive." Id.

I would argue that state enforeement of online access contracts should be subject to possible preemption under current law, although any detailed consideration of that admittedly difficult question is beyond the scope of this Article. Once an expressive work is made available to all members of the public who are willing to agree to a standard contract goveming the terms of access and use. state enforeement of that contract does, it seems to me, meet both the subject matter and equivalent nghis requirements for statutory preemption under section 301 (a). In addition, and this would be the grounds for preemption most in line with the democratic paradigm, state enforcement of online access contraets that seek systemattcally to avoid fair use, idea/expression dichotomy, or durational limitations on owner control over publicly disseminated works would "stand as an obstacle to the accomplishment and executson of the full purposes and objectives of Congress" reflected in the Copyright Act and of the fundamental purposes of the Copyright Clause, and thus should be preempted under the Supremacy Clause of the United States Constitution. See Goldstein v. California, 412 U.S. 546, 561 (1973) (quoung Hines v. Davidowitz. 312 U S 52, 67 (1941)). 
individuals. ${ }^{961}$ Few of Madison's contemporaries would have disagreed. The nascent republic, they believed, required an educated, independent-minded citizenry. Consequently, both the Copyright Clause of the Constitution and the first federal copyright statute-with their proclaimed purposes of promoting the "progress of Science" and encouraging "learning"-reflected a view of authors as educators and of literary works as instruments of pedagogy and patriotism. ${ }^{462}$

The copyright that the Founders envisioned would serve these objectives was a narrow, short-term right to make literal or near-literal copies of printed material. Today's copyright law bears only a scant resemblance to this original formulation. Our understandings of democratic governance have also evolved considerably since the founding. Today, we celebrate a degree of diversity of view, value, and experience that extends far beyond that contemplated in the early Republic. But given the central importance of a vital and pluralist civil society for democratic self-rule, then as now, copyright's fundamental role in supporting our democratic institutions has remained constant. By underwriting a sphere of self-reliant authorship, free from state or private patronage, and by placing limits on the propertization of creative expression, copyright helps to ensure the diversity and autonomy of the voices that make up our social, political, and aesthetic discourse.

Despite the intentions of some of its proponents, neoclassicist economics vitiates copyright's support for a democratic civil society. Its expansive view of copyright's scope upends copyright's delicate balance between author incentives and public access. Its exacting adherence to rarefied marketplace models sharply constricts copyright's breathing space for transformative uses of existing works, stifling the free exchange of ideas. Its reduction of authors' expression to a vendible commodity undermines copyright's promotion of political competency and disregards the importance of creative expression for our democratic institutions.

The democratic paradigm emphasizes, in contrast, that copyright is, like many institutions of civil society, in, but not of, the market. Its scope must be broad enough to assure the independence and vitality of civil society's communicative sphere, but not so broad as to smother expressive diversity. While the democratic paradigm may incorporate neoclassicist insights about how copyright operates in the market, it makes clear that copyright's paramount objective is not allocative efficiency, but citizen participation in democratic self-rule.

461. The Federalist No. 43, at 272 (James Madison) (Clinton Rossiter ed., 1961).

462. The Copyright Clause empowers Congress "[t]o promote the progress of science . . . by securing, for limited times, to authors . . the exclusive right to their respective writings." U.S. CONST., art. I, \& 8, cl. 8. The title of the first federal copyright statute was: "An Act for the encouragement of learning, by securing the copies of maps, charts, and books, to the authors and proprietors of such copics, during the times therein mentioned." Act of May 31, 1790, ch. 15, § 1, 1 Stat. 124, 124. 
The democratic paradigm has particular poignancy for copyright's central role in the computer network environment. In that context the paradigm denies the neoclassicist vision of cyberspace as a "celestial jukebox, ${ }^{\text {"N63 }}$ a place where copyright owners are entitled to full payment for each and every use of their works. It also rejects the fantasy, put forth by some minimalist copyright critics, of a hacker's heaven, a realm free from our bourgeois "obsession" with "authorship" and "plagiarism." 464 The democratic paradigm posits, instead, that copyright should be defined and delimited to engender an information infrastructure populated with a lively interplay of sustained works of authorship. Such an infrastructure-more aptly described as a digital public square-would best enhance the democratic character of civil society.

463. GOLDSTEIN, supra note 21, at 197-236, 251 (using metaphor. but disclaiming credil for its creation).

464. See supra text accompanying notes $263-68$. 
